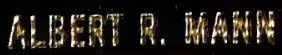

UIBRARY

COAMELE UAH. 


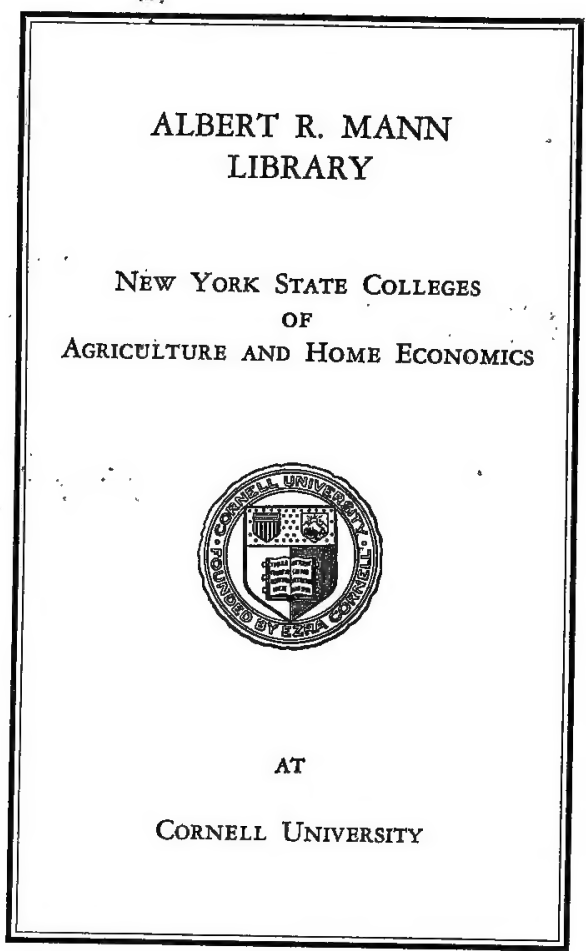




\section{SB 436.F79 Cornell University Library \\ 436.779}

Tree planting on streets and highways,

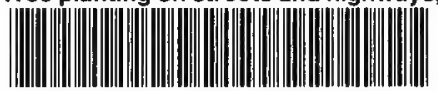

$31924002870 \quad 164$ 


\section{Cornell University Library}

The original of this book is in the Cornell University Library.

There are no known copyright restrictions in the United States on the use of the text. 


State of New York

Forest, Fish and Game Commission

\section{Tree Planting}

\section{On Streets and Highways}

Br

William F. Fox

Superintendent State Forests

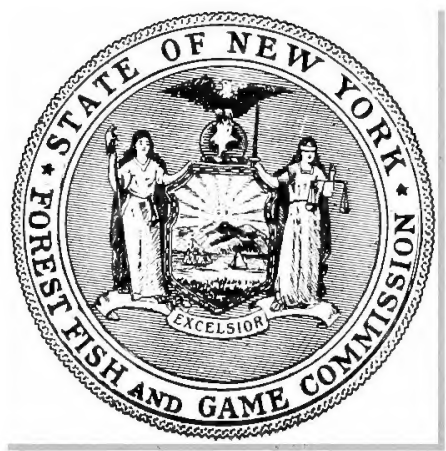

ALBANY

J. B. LYON COMPANY, PRINTERS 



\title{
Tree Planting on Streets and Highways.
}

\author{
By WILLIAM F. FOX.
}

\begin{abstract}
$\mathrm{T}$
REE PLANTING is one of the best expressions of altruism. The man who plants trees is thinking of others rather than himself. He enables people to gratify their love of the beautiful, to enjoy better health, to become more prosperous; he makes the world better and happier.

Trees purify and cool the air, increase the value of surrounding property, and are pleasing to the eye. They should be placed along the highways, on our village and city streets, on lawns and in parks, on schoolhouse grounds, on the farm, in the dooryard, and wherever shade or shelter may be needed. Planted in commemoration of persons or events, they become living monuments that endure when the inscriptions on the yellow, moss-covered marbles of the churchyard are no longer legible.
\end{abstract}

\section{Higbway Ptanting.}

Trees should be set out along every road for shade. In addition, the farm lanes can be lined advantageously with fruit or nut-bearing trees that will bring money to their owner and add to the attractive appearance of his surroundings. Objections may be made in some localities to placing trees along a public road, because their shade would tend to make it wet and muddy. If such conditions exist, the fault is in the road, and not in the trees; there are some very muddy highways along which nothing has been planted. Although a row of trees may retard somewhat the evaporation of moisture at the surface of the roadbed, at the same time they drain its foundation by the rapid absorption of water through their roots. When a roadbed is properly constructed, drained and ditched, the trees will do no harm; on the contrary, they will furnish a grateful shade to the traveler, and prevent dust without creating mud.

There are roads along which no trees are allowed, because some resident argues that the sun is needed to dry up the mud and sloughs which in spring make traveling slow and difficult. But in summer the sun-baked mud is pulverized under the wagon wheels, creating clouds of dust that are worse than the mud. With a wellbuilt highway, shaded by trees, both of these nuisances would be avoided. Even a 
poor road will permit of one row of trees, which should be placed on the south or west side, as its direction may require, to temper the heat of the afternoon sun.

One of the finest, smoothest roads in the State may be found in the Adirondack forest - from St. Hubert's Inn to the Ausable Lakes - ; and yet it is well shaded by trees that meet overhead, shutting out the sun except where the road is flecked with light that streams through the small openings in the leafy cover. But this road was constructed in proper shape, and of suitable material.

Some States - noticeably New York and Massachusetts - have made large appropriations recently for good roads, and these annual expenditures will not only be continued but will probably be increased. With the money thus provided long lines of stone highways with perfectly drained roadbeds have been constructed, and with each succeeding year many more miles will be finished. We are entering on an era of good roads. But the good work of the road-builders will not be complete until trees are planted at proper distances on each side of the highway. In his Annual Report for I90I, Hon. Edward A. Bond, State Engineer and Surveyor (New York), states that the actual cost of 134 miles of stone macadam roads was $\$ 7,955$ per mile. Now it takes 196 trees to plant each side of a highway for one mile; and the cost of the planting will be less than two per cent of that of the road construction. Having expended over $\$ 7,000$ on the roadbed, there surely should be no objection to paying $\$ 150$ more in order to have a cool, shady driveway. Of course, "dirt" roads have been constructed in some localities under the Good Roads Law at a much less cost per mile; but the argument still holds good, in that the work will not be complete until the trees are planted. Why not amend the law so as to include the tree planting?

\section{Mighway Law.}

The law of 1869 , which is still in force, provides that any inhabitant liable to highway tax who shall plant by the side of a public road "any forest shade trees or fruit trees" shall be allowed in abatement of his highway tax one dollar for every four trees set out. Similar laws for the reduction of road taxes, or for the payment of a bounty, have been enacted in other States-Massachusetts, Connecticut and Pennsylvania. In New York the law specifies that Elms must be planted, at least seventy feet apart; that Maples "or other forest trees" shall not be set nearer than fifty feet, except Locusts, which may be set at intervals of thirty feet. Fruit trees must be planted at least fifty feet apart. Proper penalties are prescribed for any one who shall injure a tree, or who shall hitch a horse or any animal to, or leave the same standing near enough to injure a tree used for shade or ornament, at 

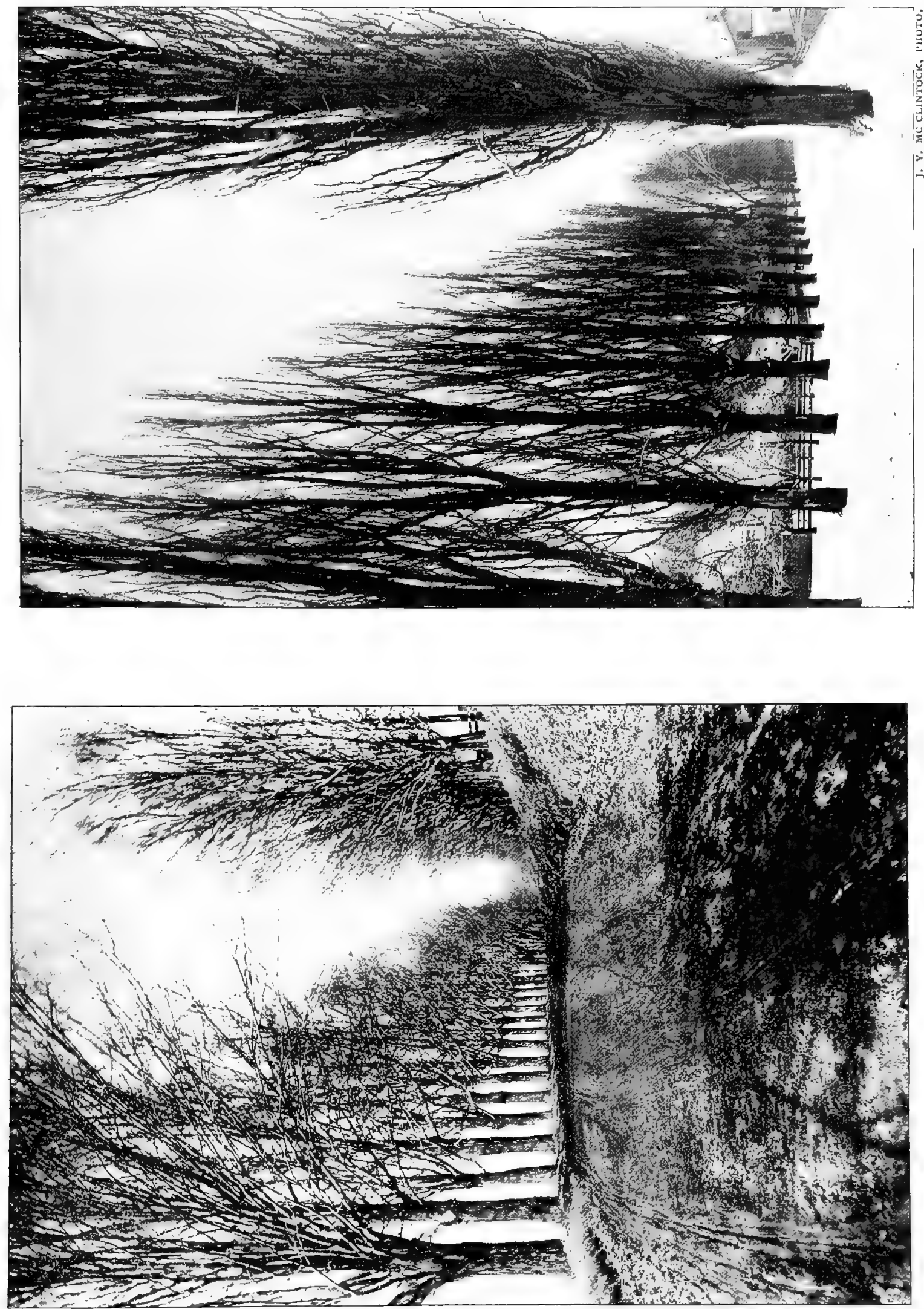

"any schoolhouse, church, or public building, or along any public highway." The kinds of trees mentioned in the law referred to are well adapted to highway planting; and the distances apart at which they must be set are based on the space which each species is known to occupy. While the distances specified in the State law are correct as regards highway planting, shorter intervals may be used in cities, where trees seldom attain a height and spread equal to that of the same species when grown in the open country.

\section{Selection of Trees.}

Nothing has been found that will equal our American Elm and Hard Maple for wide roads and double rows. As our Elms often attain a spread of one hundred feet it is evident that the seventy feet demanded in the law is none too wide a space. The trees should be allowed to assume their full size and natural shape without crowding or interfering with each other. Transplanted, or "second growth," Hard Maples along a country road attain a large size and beautiful appearance, which require all of a fifty-foot space. Other species-Oaks, Basswood, White Ash, Locust, Willow, Horse Chestnut, Black Cherry, Buttonball, Beech and the two Soft Maples - can be used with good results in order to obtain variety, By planting the Scarlet Oak, Red Maple and Pepperidge, the brilliancy of the autumn coloring can be enhanced by the bright reds displayed by the leaves of these species.

In some localities the Elms have been killed or seriously injured by insects; and these pests have wrought a widespread destruction recently anong the maples in the Adirondack and Catskill forests, and in village streets. The Horse Chestnuts also have been defoliated; and it may be that other species will be injured in time. While it is difficult to check the ravages of insects when large forest areas are attacked, this evil can be controlled, if not preverited, where the trees along our highways and streets are endangered, as shown by the successful use of spraying apparatus or other remedies. The planting of any particular species should not be discontinued merely because the trees may be attacked at some future time by insects. The good work should go on, and if, in years to come, there should be a recurrence of this evil we can safely trust to the remedies prescribed by our entomologists for the prevention or abatement of the pest.

There are some forest trees which are not adapted to roadside planting, because they assume a different form when grown in the open, the branches growing lower down and the trunk failing to reach its usual height, although it may attain a large diameter. For this reason, the Birches, especially the Yellow Birch, are not desirable for streets or roadside use. 
Nut-bearing trees, the. Chestnut, Butternut, and Hickories, are available for highway planting. They are handsome, large trees, each species having peculiarities of habit that make it worth the notice of an observant traveler, particularly in winter, when the pleasing arrangement of their limbs can be better seen and studied. Their branches may suffer to some extent from boys in quest of nuts; but that is liable to happen wherever these trees may stand. In some European countries the roads are lined with fruit trees. But there it is well understood that the fruit, though it overhangs the highways, belongs to the farmer, whose property is respected accordingly. In this country, where widely different ideas prevail, it might be necessary to concede the traveler's claim in case fruit trees were planted along or within the "right of way."

\section{Street Planting.}

There are many reasons why trees should be planted in cities and villages. During the hot days of summer the streets which are shaded by trees are preferred to those which lack this protection. The temperature is much lower; and as the pavements are not exposed to the glare of the sun, there is less of reflected heat. The streets that are lined with shade trees are more attractive to the eye; and their superiority is readily apparent when compared with those on which there are no trees. The shaded streets being cooler they are more desirable for residences, and, other things being equal, property is more valuable and commands higher rents. The air is purer by reason of the foliage, which inhales carbonic acid and exhales oxygen. The leaves absorb the poisonous gases generated in hot weather by the decomposition of animal and vegetable matter, and thus an active source of disease is eliminated. During hot summer days the diseases incidental to that season are not so prevalent in streets and localities which are protected from the heat of the sun by large overhanging trees.* At a meeting of the New York Medical Society a resolution was passed in which the opinion was expressed that "one of the most effective means for mitigating the intense heat of the summer months, and diminishing the death rate among children, is the cultivation of an adequate number of trees in the streets."

The city of Washington is justly known as one of the most beautiful cities in America on account of the seventy thousand trees that adorn its streets; and there are many New England towns famed for their attractive appearance, due largely to

* See "Vegetation a Remedy for the Summer Heat of Cities." By Stephen Smith, M. D., LL. D. Appleton's Popular Science Monthly, February, I89g. 


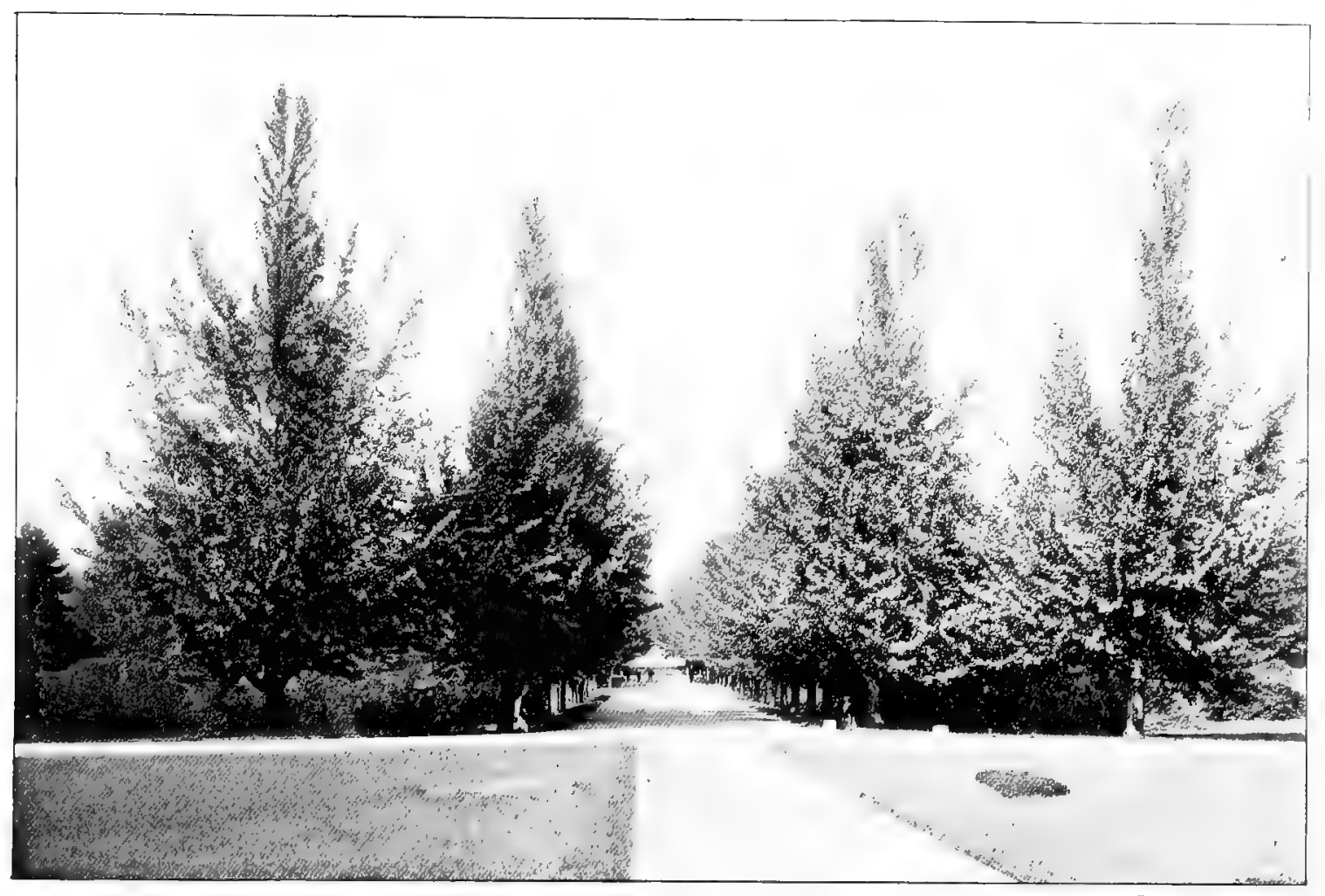

GINKGOS. - AVENUE I.EADING TO DEPARTMENT OF AGRICULTURE, WASHINGTON, D. C.

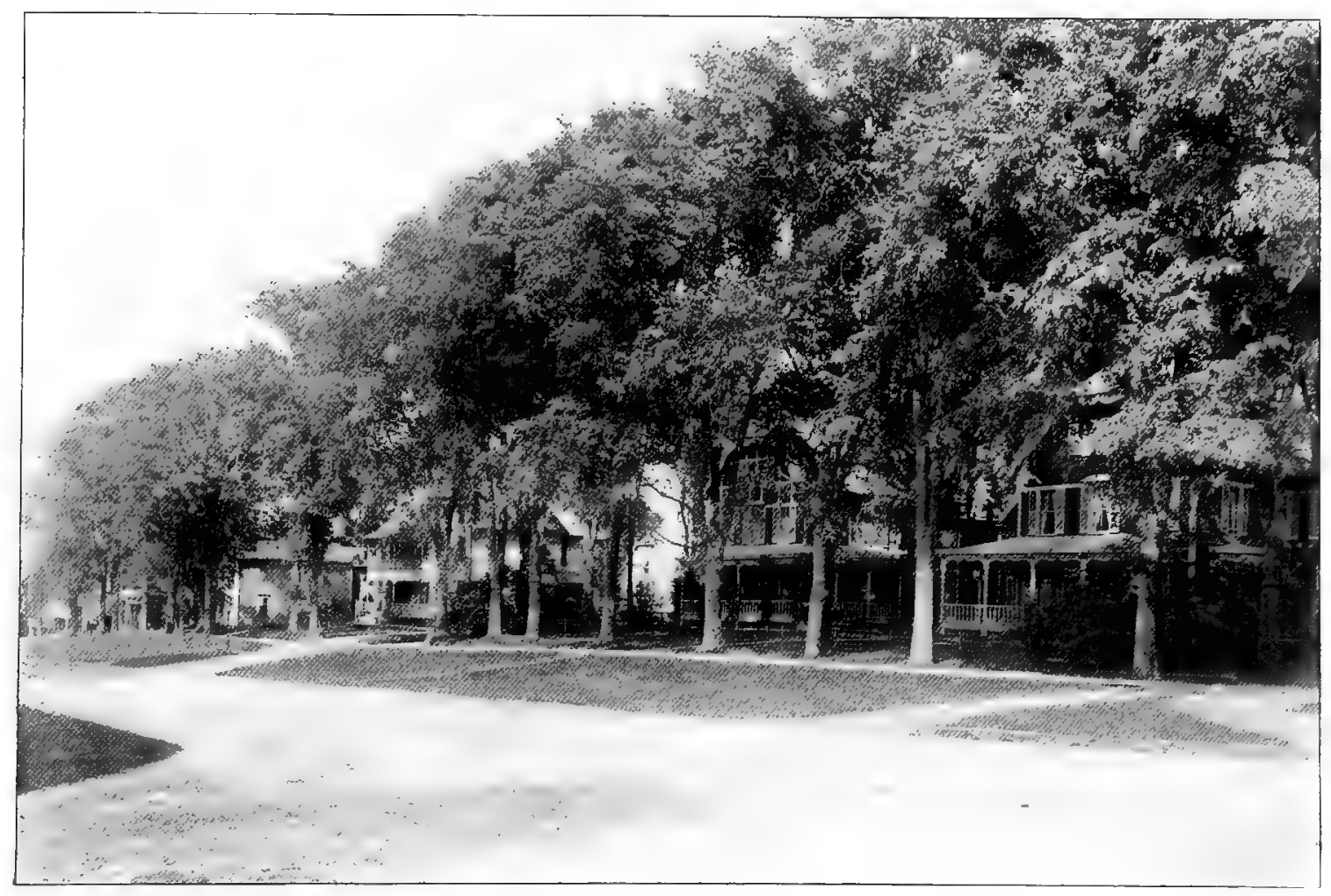

THE ELMS OF LENOX. 

the beautiful trees planted by village improvement societies. It is said that Paris has 80,000 shade trees, and that $\$ 60,000$ are expended annually in caring for them and planting additional ones. Both Washington and Paris have nurseries in which seedlings of desirable species are propagated with special reference to the requirements of street planting. Poorly developed plants or saplings are discarded, and only the straight, thrifty ones are selected for use on the city streets.

In street planting care should be exercised to select species which, when fully grown, will be of a size suitable to the width of the street; and in making a choice only such should be selected as are best adapted to the peculiar conditions which influence their growth in cities. Some trees that can be safely used for road planting in the country are too susceptible to the deleterious influences of the smoke, dust, gas, and pavement of our towns.

Along country roads or village streets, saplings transplanted from some neighboring grove or forest may be set out; but for city streets nursery stock alone should be used. In fact, it would be better to buy nursery trees for village planting also, unless compelled to use the other for economical reasons. If one must go to the forest for young trees, pains should be taken to obtain as straight, thrifty and perfect specimens as possible.

\section{Selection of Species.}

In making a choice the first thing to be considered is the width of the street; also, the width of the sidewalk or nearness of the houses. Some trees, the Elm for instance, will injure the foundation walls of a house by the pressure from its farspreading roots. Where the house stands near the curb, trees with a tap root are preferable.

The following list includes all, or nearly all, the species which are desirable for street planting, most of which are quite common throughout New England and the Middle States. They are named in the order of their desirability, although in some instarces their preferment is somewhat a matter of taste, concerning which any discussion would be.a waste of time.

Wide streets.

American or White Elm.

Hard or Sugar Maple.

Tulip Tree.

Basswood (Linden).

Horse Chestnut.

\section{Narrow streets.}

Norway Maple.

White or Silver Maple.

Red Maple.

Ailanthus.

Cucumber Tree. 
Sweet Gum.

Sycamore (Buttonball).

White Ash.

Scarlet Oak.

Red Oak.

White Oak.

Honey Locust.

American Chestnut.
Ginkgo.

Bay Willow.

Pin Oak.

Red Flowering Horse Chestnut.

Black or Yellow Locust.

Hackberry.

Hardy Catalpa (speciosa).

Lombardy Poplar.

In any attempt to secure a comprehensive variety it should be remembered that, including the conifers, there are over five hundred native species in the United States and Canada, and that there are over ninety in the Middle and New England States. Many of these are used in forestry work, but are not adapted to streets and highways; and many others are desirable for lawns or parks but nowhere else.

The Elm stands first on the list by right of its superior size, beauty, and adapta. bility to street planting. It is rapid in growth, withstands transplanting and pruning better than most other kinds, and will grow on almost any soil. Its habit is such that any pruning of the lower limbs is seldom necessary, a valuable feature in a street tree. It thrives not only on country roads and village streets, but also in our larger towns. New Haven has attained national fame as the "Elm City," on account of the many beautiful trees of this kind which line its streets. There are various forms of the American Elm. Emerson, in his "Trees of Massachusetts," describes three distinct shapes. The most desirable one for a shade tree is that with the umbrella-shaped top, and slender, pendant branches on its outer edge. In transplanting or in giving orders to a nursery, care should be taken to secure this particular form. The English and Scotch Elms have been planted extensively in some places; but as these species are inferior in appearance and much more liable to attack from insects their use should be discouraged. The English Elm retains its foliage longer each fall, but that is all that can be said in its favor; in fact, all the species introduced from Europe hold their leaves when most of our native trees are bare.

The Hard Maple or Sugar Maple is so well and favorably known as a shade tree that it is unnecessary to dwell here upon its beauty and symmetrical proportions. It is seen at its best in village streets and along country roads, where the conditions are better suited to its fullest development. In the crowded streets of large towns this species, in some places, has been unable to withstand the effects of smoke, dust and other unfavorable conditions. But it can be planted with good results on streets where the houses stand on large lots, with plenty of ground or wide lawns 
around them. On city blocks, where the houses are in solid rows, preference should be given to the Norway Maple, a nursery tree which resembles the native Hard Maple closely, although not so large. The Norway puts on its leaves earlier in spring, and retains its verdure later in the fall. The varied and brilliant autumnal colors displayed by the leaves of our native Hard Maple make this species desirable for ornament as well as shade. No other tree combines so many shades of color in the fall - scarlet, orange, yellow, and green. These different hues may be seen on one tree, often on one branch, and sometimes on one leaf.

The Tulip Tree will compare favorably with the Hard Maple in height.and beauty. In favored situations it attains a height of 125 feet or more, with a diameter of six to eight feet. It bears transplanting well, grows rapidly, is very hardy, and is free from destructive insects. The constant, tremulous motion of its broad leaves gives it a lively, attractive appearance. The limbs of the mature trees are more or less curved, producing a beautiful effect, which is heightened by the straight lines of the tall mast-like trunks. In the latter part of May it decks itself with terminal flowers of a dark, rich yellow, streaked with green and orange. The Tulip Tree cannot be transplanted successfully except when it is of a small size.

The Basswood, or American Linden, commends itself to the lover of trees by its ample shade, fragrant flowers and bright green foliage, which in spring contrasts well with its dark colored branches. In the fall its leaves assume a rusty hue that detracts somewhat from its appearance then, especially as most of the other trees are displaying their autumnal coloring at that time. In the excurrent character of the trunk and arrangement of its branches the Linden displays a graceful habit after the leaves have fallen, making it an attractive and desirable tree in winter. The curious, ribbon-like bract to which the pea-shaped seeds are attached makes it in early summer an interesting study to the passer-by. The Linden is extensively planted as a shade tree in Holland and some other European countries. In Berlin one of the principal avenues, Unter den Linden, takes its name from the trees that shade its walks and driveways. Botanists are apt to regard this tree with a peculiar interest, for the father of Linnæus, the Swedish naturalist, took his family name from a large, beautiful Linden, or Linn, that stood near his home.*

The Horse Chestnut is the earliest of our trees. Before the buds have opened on many of the others, and while the willows are showing only a "green mist" the Horse Chestnut unfolds its cunningly packed leaflets to the sun, a welcome sight to those who are waiting and watching for spring. Its large leaves afford a shade more

* At that time many of the Swedes had Christian names only, and when they wanted a family name it was customary to adopt that of some natural object in the vicinity - Berg (hill), Strom (stream), etc. 
dense than that of any other tree. In parks and on lawins, where its growth is not restricted, this tree assumes a grand, massive appearance that always arrests the eye. In early spring it is gay with large white and pink flowers whose erect panicles standing on the upturned tips of the branches are suggestive of a leafy candelabra, an effect that is heightened when one remembers the peculiar appearance in this respect of the tree in winter. In most families of plants, the order of opening in the flowers is either from the bottom upwards - or from the top downwards proceeding to open regularly up or down. Mr. Joseph. Meehan observes that in the Horse Chestnut there are open flowers simultaneously on every portion of the thyrse or spike, so that the tree seems to be covered with flowers as if by magic in a growth of but a few days.* Objection has been made to the Horse Chestnut because at times there is too much litter on the sidewalks under it. But if people sweep their sidewalks daily there:need be no trouble from this source; and if they do not keep their walks clean they will neglect their trees also, in which case it is immaterial what species is planted. The question of insects is discussed later on. The Horse Chestnut, like the Ailanthus and Lombardy Poplar, is not indigenous to the United States, having been introduced here in 1746. In April of that year John Bartram, writing to Peter Collinson, $\nmid$ acknowledges the receipt of the seeds, of which he had hopes, as' "some seemed to be pretty sound." Gen. Brisbin notes that the first tree is said to be still standing on the estate of Mr. Lemuel Wells, Yonkers, N. Y. John Evelyn, in his famous Silva, written in 1662, says that the Horse Chestnut derived its name from the fact that the fruit was used for "curing broken-winded horses, and other cattle, of coughs." But the peculiar shape of the scar left on the twig by the fallen leaf, which resembles the track of a horse's hoof and imprint of the nails, is very suggestive when taken in connection with the translation of hippocastanum, its Greek or botanical name.

The Sweet Gum, or Liquidambar, so named from the fragrant balsam which exudes when the trunk is wounded, is an ornamental tree of about eighty feet in height and two feet in diameter, attaining in some localities a much greater size. It is a rapid grower and thrives on almost any soil. Its glossy, star-shaped leaf makes it a favorite with all students of leaf forms. The tree is interesting in winter also on account of the corky ridges or wings attached to the twigs and smaller branches which give it a peculiar appearance. In autumn its foliage changes to a deep

\footnotetext{
* Meehan's Monthly. Philadelphia, Pa., May, rgo2.

† Memorials of John Bartram and Humphrey Marshall. William Darlington, M. D., LL. D. Philadelphia; Lindsay \& Blakiston. 1849.

‡Gen. James S. Brisbin, U. S. A. Trees and Tree Planting. New York: Harper \& Brothers. 1888.
} 


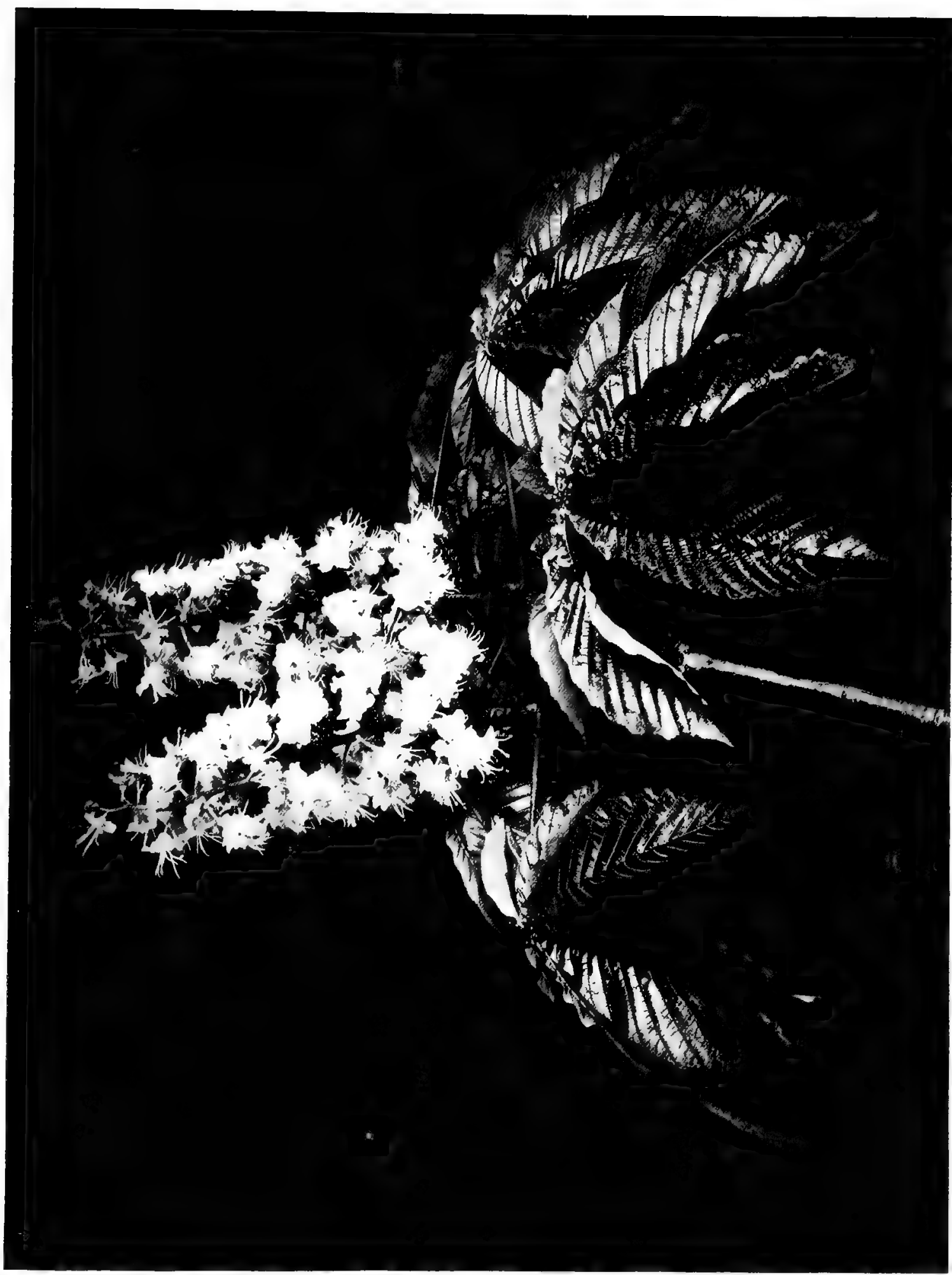

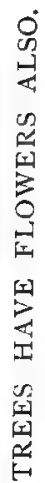






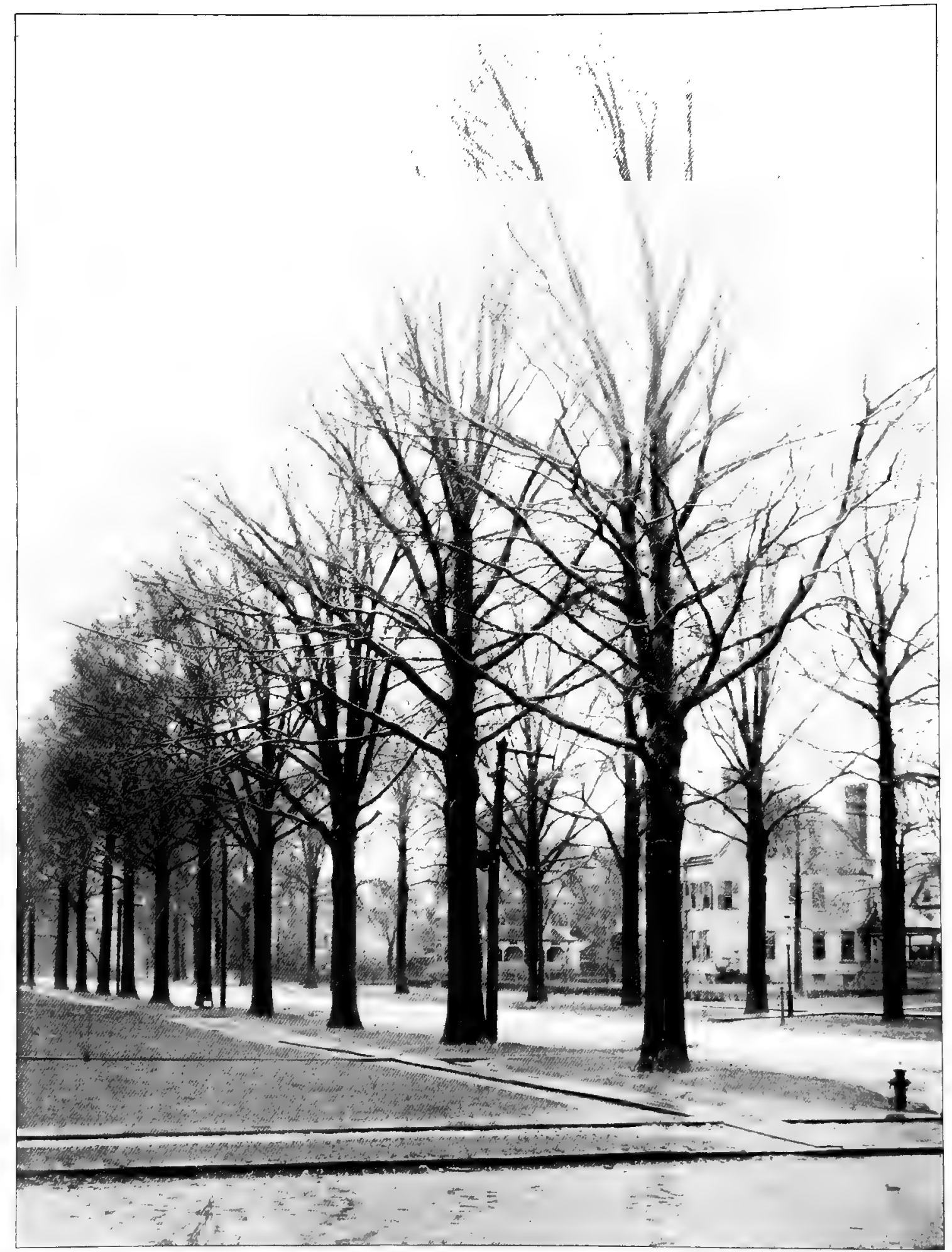

THE OAKS OF FLUSHING.

I'IN OAKS. 
crimson interspersed with yellow. Where a variety of species may be deemed desirable, this tree should not be omitted, as it can be used in street planting for several blocks with good effect.

Of the various species of Ash, the White Ash is the one best adapted for ornament and shade. It may be classed fairly among the large trees, the trunk attaining considerable height before it subdivides, which, like the Elm, makes it desirable for street purposes. Its foliage is pleasing in appearance, growing in irregular, waving masses, but without any abrupt or broken outlines. The Ash, however, is among the last to put out its leaves in spring, and among the first to lose them in the fall. In the latter season its foliage assumes a variety of colors, violet, brown, and dark chocolate. Wilson Flagg notes that the Ash is the only tree that shows a clear brown as one of its regular series of tints in the living leaf. Like most trees with compound leaves it sheds its spray with the leaves in fall, leaving naked angular branches that detract from the beauty of its habit in winter. Its freedom from disease and insects commends it to all tree planters.

In street planting the Oaks have hitherto been used but sparingly. The few that appear here and there along country roads seem to owe their existence to accident rather than design. This is probably due to their slower growth, a disadvantage which is fully offset by their hardiness and longer life. The Oak is a noble tree, its size and sturdy character entitling it to a prominent place in our streets and parks. In growth it is no slower than some other species which have been freely planted. The village of Flushing, L. I., is noted for the beautiful Oaks that shade some of its streets.

The Scarlet Oak is a desirable tree for many reasons, one of them being the crimson leaves which charm the eye long after the other trees are bare. Its foliage is unusually persistent, and in some seasons the ruddy glow of its leaves may be seen in brilliant contrast with the first snow.

The Red Oak is the most rapid in growth of all the Oaks, attains a great size, and exhibits the best proportions of any of the acorn-bearing species. It has less of the gnarled and contorted habit so characteristic of the Oaks in general.

The Pin Oak may be described as a middle-sized tree, available for roads and streets of medium width. In thrives best on moist ground. In shapely habit and general massing of foliage it will compare favorably with any of its genus, while the smooth, deeply pinnatifid leaves, bright green on both sides, add greatly to its beauty. The lowest branches of the Pin Oak are generally the longest, a peculiarity that distinguishes it from most of the deciduous trees, and which emphasizes its beautiful proportions, giving it a conical outline. Like all the Oaks its leaves are 
among the last to fall, and; without displaying brilliant colors, they contribute materially to the variety of autumnal tints. Its immunity from insects, fairly rapid growth, and the satisfactory results that have hitherto attended its use, make it a desirable tree. The famous Oaks that beautify the streets of Flushing include a large number of this species.

The White Oak is superior in vigor and longevity. It does not grow as tall as the Red Oak, but attains a greater spread. Its red and russet-colored leaves are very persistent, often clinging to the tree during the entire winter, a feature regarded by many with unfailing interest. It is to be hoped that, with the revival of tree planting in our towns and villages, the Oaks will receive the consideration which their many good qualities deserve.

The Honey Locust is the latest of our trees to put forth its foliage. This is the only thing that can be said against it, and that is not always a disadvantage. When its pinnate leaves do appear the beauty of their waving, feathery spray fully excuses any complaint of tardiness. It is a tall, graceful tree, free from insects thus far, unaffected by smoke or dust, and well entitled to a place along our streets and in our parks. Where a dense, cool shade is wanted the Honey Locust would not answer the purpose, owing to its open foliage through which the sunlight streams freely; but this peculiarity makes it desirable for lawns or places where plants or grass might suffer from too much shade. A distinctive feature may be observed in the sharp, stout thorns, three to five inches long, often three-forked or growing in clusters on the trunk. The tree takes its common name from the sweet contents of the long, purple bean pods that hang conspicuously on the branches after the leaves have fallen.

The Common or Yellow Locust is one of our most beautiful trees on account of its profusion of pinnate leaves, and the pendant racemes of white flowers which in June fill the air with an agreeable perfume. The Locust is reputed to be a favorite nesting place for birds, its spiny stipules furnishing protection from many of their enemies. Prof. Sargent, in his Silva of North America, notes that the Yellow Locust continues to grow until the beginning of autumn, and that the ends of the branches in summer are covered with young light yellow-green leaves which stand out conspicuously against the dark background of the older foliage. This tree grows rapidly, and its size makes it available for streets of medium, rather than narrow width; but owing to the brittle character of its branches it should not be placed where it will be exposed to strong winds. This species has one peculiar advantage as a lawn or roadside tree in that the grass beneath its shade is always green owing to the fertilizing property of its leaves, which like all leguminous plants enriches the soil. But 



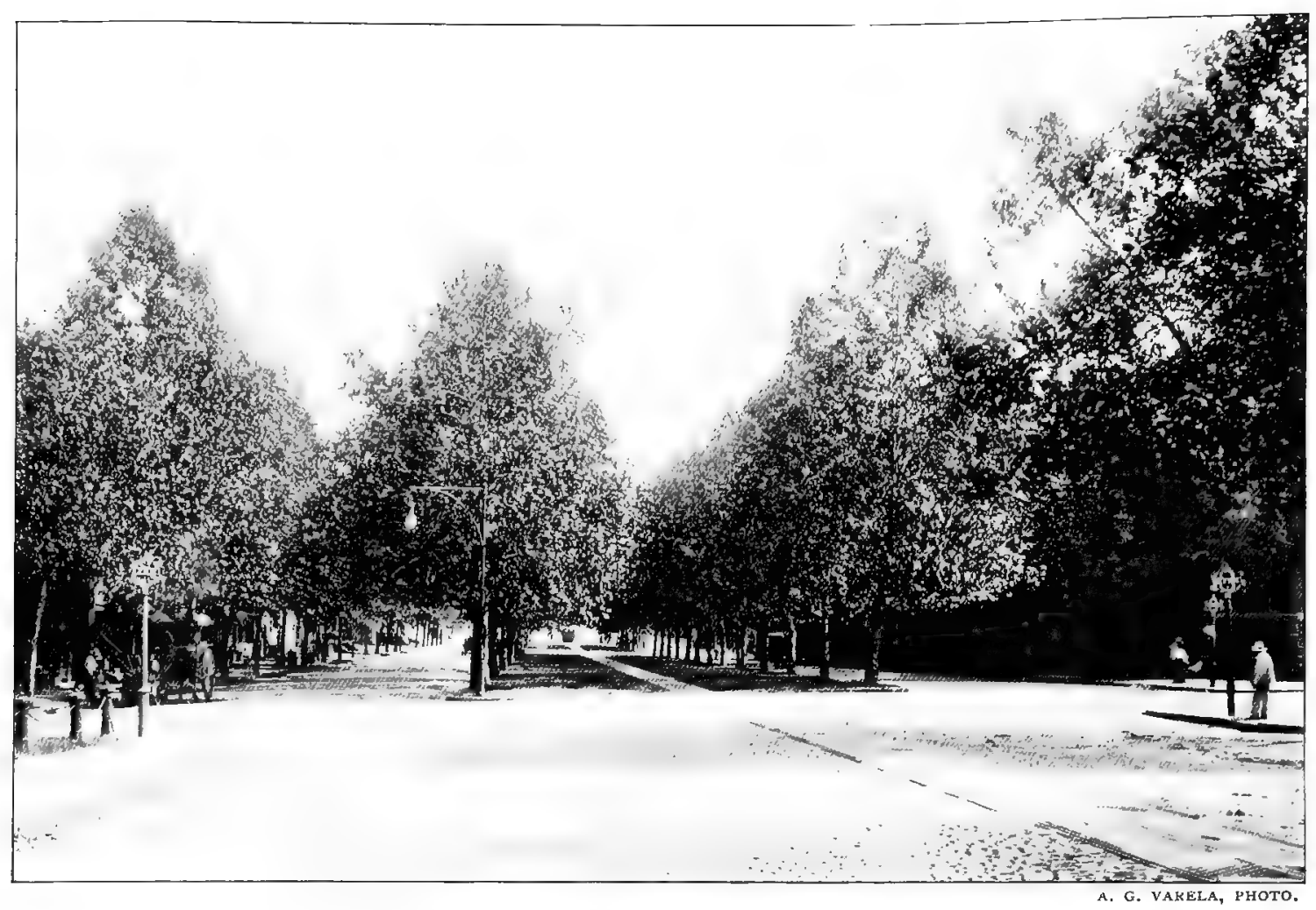

DOUBle ROW OF SYCAMORES. - INDIANA AVENUE, WASHINGTON, D. C.

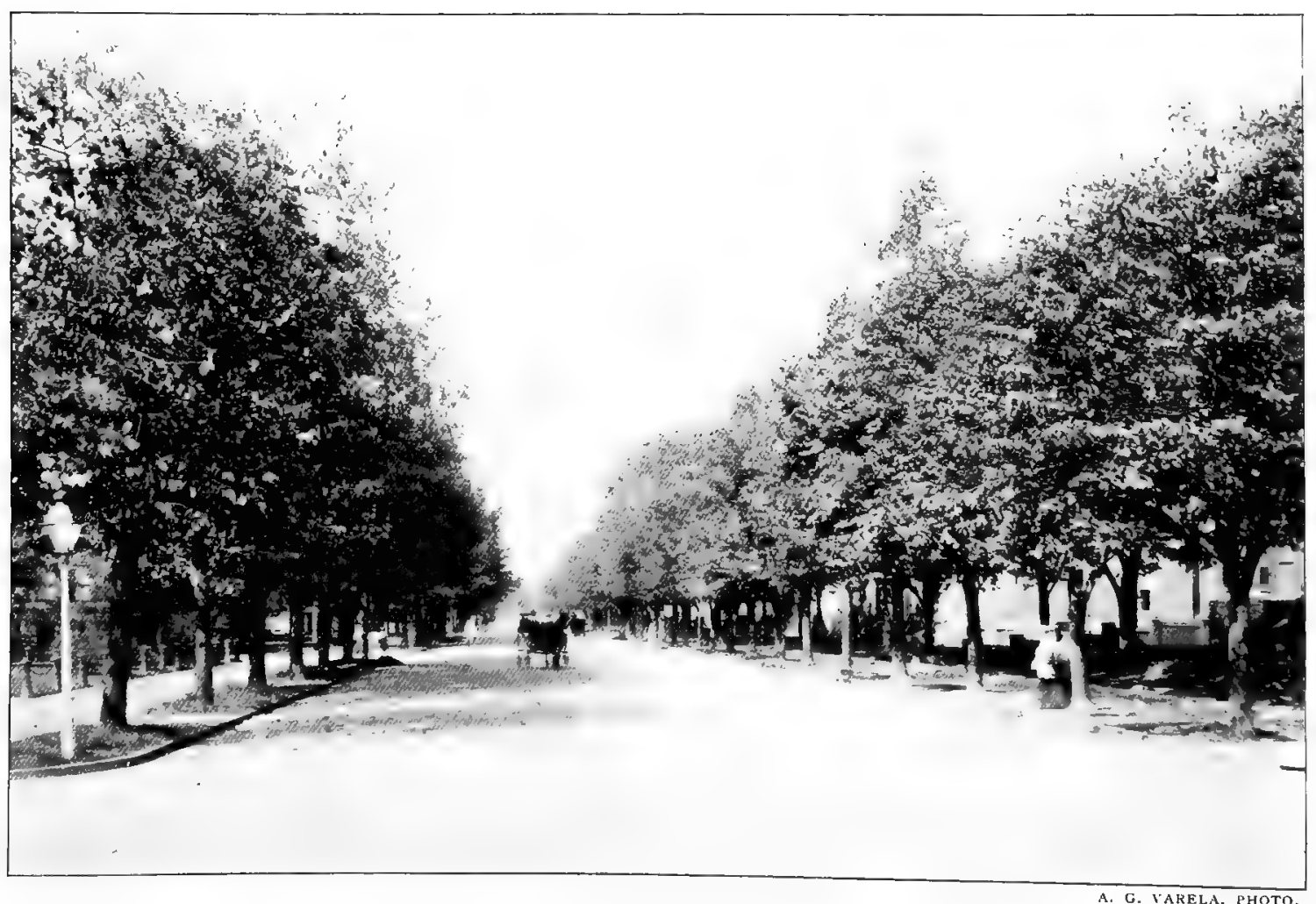

LINDENS. - MASSACHUSETTS AVENUE, WASHINGTON, D. C. 
the Locusts have suffered almost everywhere so much from the attacks of insect borers that this liability should be well understood before planting them to any great extent.

Where rapid growth and great size is desired, the Sycamore, or Buttonwood, may claim a place. Its lower branches are high above the ground, affording an open space beneath the tree - which is often desirable when planted near a house - and furnishing ample shade without obstructing the view of the street or road; but owing to its irregular, inferior habit and liability to fungal diseases, it should be used sparingly in streets or parks, and only where variety is desired. The European Sycamore, or Oriental Plane, which resembles the American species closely, is preferable in every respect, and can be obtained from any nursery. The Sycamore is easily recognized by its peculiar bark, which falls off in flakes from the lower part of the trunk, giving that portion of the tree a scabby, spotted appearance, while the upper part of the trunk and the branches are smooth and of a creamy white. It is known also by the "buttonballs" hanging from its branches, a dry, globular fruit filled with seeds, and conspicuous in winter. Tree students, in their outdoor studies, are always pleased to note the conical bud hidden under the base of each leaf stalk and fitting so nicely into the cone-shaped recess in the petiole. It is an interesting tree, and, as found in the lowlands of the Mississippi basin, is the largest of all our deciduous species. The Thames Embankment Boulevard, a famous avenue in London, is lined with Sycamores.

Hitherto the American Chestnut has not been planted on our streets or roads; but there is no good reason why it should not be given a place occasionally. It grows very fast, attains a large size, is handsome in form and proportion, and fulfills all the requirements of a first-class shade tree. The boys might prove troublesome when the fruit is ripening; but that is all that can be said in objection, a difficulty easily obviated by a little police work during the short time in which the burs are opening. The Chestnut, too, is not without its claim to beauty. In July its branches are covered with a profusion of cream colored catkins that attract the eye and enable one to identify it then, even at a great distance.

The White or Silver Maple is a favorite shade tree in both town and country, surpassing all other species, except the Carolina Poplar, in rapidity of growth. It bears transplanting as well as any other, withstands pruning, and is exceedingly graceful. Its slender, pendant branches are easily swayed by the breeze, giving it a waving, flowing appearance, that is made still more attractive by its silvery hue when agitated by the wind, the under side of the leaves having a whitish color which is then exposed to view. The deeply cleft shape of the leaves adds also to 
its beauty. Where it is desirable to obtain shade as soon as possible, and at the same time have a beautiful tree, this species should be selected. Of the two soft maples the White is readily distinguished from the Red at first sight by the upward curve of the tips on the lower branches, a distinct peculiarity which adds to the pleasing outlines of this tree.

The Red Maple is a rapidly growing tree of attractive appearance, the light gray bark on the limbs affording a pleasing contrast to its bright green foliage. In addition to many of the good qualities belonging to the maple it displays a scarlet leaf in autumn, which changes later to a dark crimson. Its foliage is the first to change color, some trees showing their red leaves early in August, and the conspicuous red flowers make it noticeable also in early spring. As it seldom attains its full size when planted in cities it is well adapted to narrow streets.

There seems to be a general prejudice against the Ailanthus, or Ailantus as sometimes spelled; and yet it withstands the injurious effects of city life better than any other species. It has a peculiar beauty also in the graceful sweep of its large pinnate leaves, suggestive of the Stag Horn Sumach, which remain green until they fall. Objection has been made to the disagreeable odor of its flowers, but this lasts for only a few days, and can be entirely obviated by planting pistillate trees. The peculiar bark, in which there is traced an arabesque-like pattern, is an interesting study, while the large clusters of reddish bronze samaras on a pistillate tree in autumn make it a thing of beauty and object of enjoyment worth a long walk to see. Brisbin states that it was first introduced in the United States by Mr. William Hamilton, in 1784 , and that a sucker, planted from the original tree in 1809 , is at present standing in the Bartram Botanic Garden. In $1820 \mathrm{Mr}$. William Prince, a nurseryman at Flushing; Long Island, imported the Ailanthus from Europe, and from this stock most of the trees in. New York and its vicinity were supplied. Although an exotic it reproduces itself readily, its winged seeds often lodging in the cracks of paved areas, where the young trees may be seen growing in nooks and corners along the house line. The Ailanthus is not only immune from insect blight, but there is no species that can approach it in the ability to thrive in the poor soil and amid the unfavorable conditions of city streets.

The Cucumber Tree is a magnolia of stately growth, with a trunk from sixty to eighty feet in height. It grows rapidly, develops a pyramidal form, and fulfills all the requirements of a desirable shade tree. It is advisable to use a small tree in transplanting. Its common name is due to the fruit, which, when green, resem. bles somewhat a small cucumber.

For narrow streets, or, where there is little space between the house line and the. 
curbstone, the Japanese Ginkgo is well adapted, as it does not attain a wide spread. When fully grown it is over sixty feet high, but in New York, with its cold winters, this species does not grow to its full size, although hardy and thrifty in other respects. This tree is not slow in growth, but still it furnishes little shade until it approaches maturity, when it assumes a tapering form with ample foliage. Thus far the Ginkgo has been free from destructive insects. Its peculiar, fan-shaped leaves, in form like those of the maiden hair fern, retain their olive green color until early autumn, when they change to a rich yellow or orange. Though not an evergreen it is a conifer, of the yew family, a distinction seldom noticed by many who are familiar with the appearance of the tree.

The Willows furnish some species that are available for shade and ornament. The one best adapted for street planting is the Bay or Laurel-leaved Willow. As it is not a large tree it should be reserved for narrow streets. The slender, tapering leaves, which are bright, glossy, and of a deep green on both sides, form a conspicuous feature of this species.

The Hackberry is a medium sized tree, which, in its general appearance, resembles the Elm. Its straight trunk does not divide until it has attained considerable height, a peculiarity which is an advantage in a street tree; but, as its roots generally rise above the ground for some distance from the trunk it is better adapted to village streets or wide avenues, where the flagstones of the sidewalk do not extend to the curb. While it is not a tree of the first magnitude, it is generally too large for narrow streets. Though a native it is rarely found in our woods; but young trees can always be obtained from nurseries. It is so uncommon that, aside from botanists, foresters, or lovers of trees, it is seldom recognized by its right name. There are places in New York where some lone specimen is described by the people in its vicinity as "the lost tree" or "the unknown tree," and is the subject of marvelous stories as to its origin or characteristics. The Hackberry is easily identified, however, by its elm-like leaf and habit, by its peculiar bark, covered with hard, warty, excresences, and by the small, dark red, berry-shaped fruit, which clings to the stems long after the leaves have fallen - often during the entire winter. Its rapid growth under all ordinary conditions of soil or climate, together with its freedom from disease and insects, entitles it to consideration in making a selection.

The Hardy Catalpa is a tree 50 to 70 feet high, of erect habit and ornamental character - a desirable kind in certain situations. In June it is resplendent with white or violet-tinged flowers, growing in large, upright, pyramid-shaped clusters. Objection has been made to the Catalpa as a street tree, because it is liable to injury 
from people who persist in breaking off the flowering branches. For this reason the lower limbs should be trimmed sufficiently to prevent any injury from this source. The leaves, which are the largest seen on any of our shade trees, show no pleasing color in the fall, but turn black at the first frost. When stripped of its broad leaves the branches have a coarse blunt appearance, relieved somewhat by the display of long slender pods that hang in profusion from their tips. There are two American catalpas, and also a Japanese species, with intergrading forms or variants which necessitate some care on the part of a purchaser, for some dealers have not supplied pure seed when the Hardy Catalpa (C. speciosa) was called for.

The spire-shaped, erect form of the Lombardy Poplar makes it available for narrow streets and sidewalks. A single tree of this species, properly placed in a park or lawn, often makes an effective addition to the beauty of the landscape. As its branches are fastigiate, pointing upwards at a sharp angle with the trunk, it has a peculiar fascinating appearance when the wind is blowing, the upper part of the tree waving with a graceful, feathery motion, unlike that of other species. It has the advantage of rapidity in growth which, in turn, is offset by its short life. It casts but little shaäe, and so its use on country roads should be discontinued. But it is a great favorite as a road tree in some parts of Europe, especially in France, where it may be seen in unbroken rows stretching away for many miles.

The European White Birch or Weeping Birch has a pendant habit with small, finely shaped leaves that render it very attractive, especially when standing alone on a lawn where there is nothing to detract from its graceful outlines or the swaying movement of its drooping branches. If used as a street tree it should not be planted along the curb, but set at a proper distance within the fence line where its white bark will be less liable to injury. Where an entire block or street is thus planted, a striking uniformity is obtained as shown in the accompanying illustration.

The reasons for including certain trees in the foregoing list, and also the omission of others, may be questioned by some whose experience in arboriculture makes them competent authorities in everything relating to tree planting; but the list is not offered as furnishing anything like a definite, absolute rule. As already stated, the proper selection of trees for streets and roads is largely a matter of opinion and taste, replete with pros and cons. It would be presumptuous for any one to attempt to offer a list that would meet all requirements with absolute certainty. The names submitted here are offered in the way of suggestion rather than authoritative information, and are intended for the benefit of those who may not have the opportunity or inclination to study the question exhaustively.

While it is well to give a decided preference to our native trees, this should not 


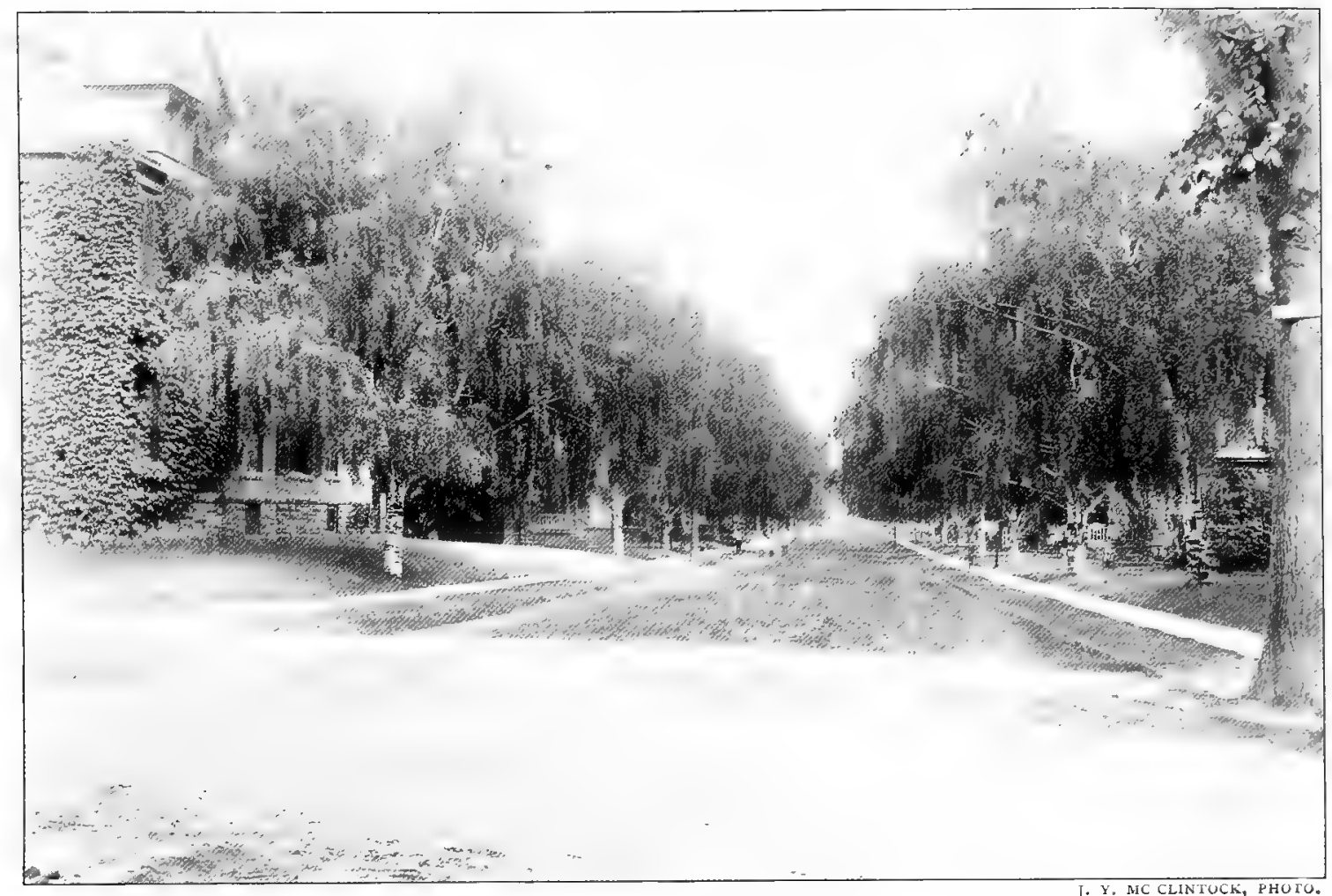

WHITE BIRCHES.-ROCHESTER, N. Y.

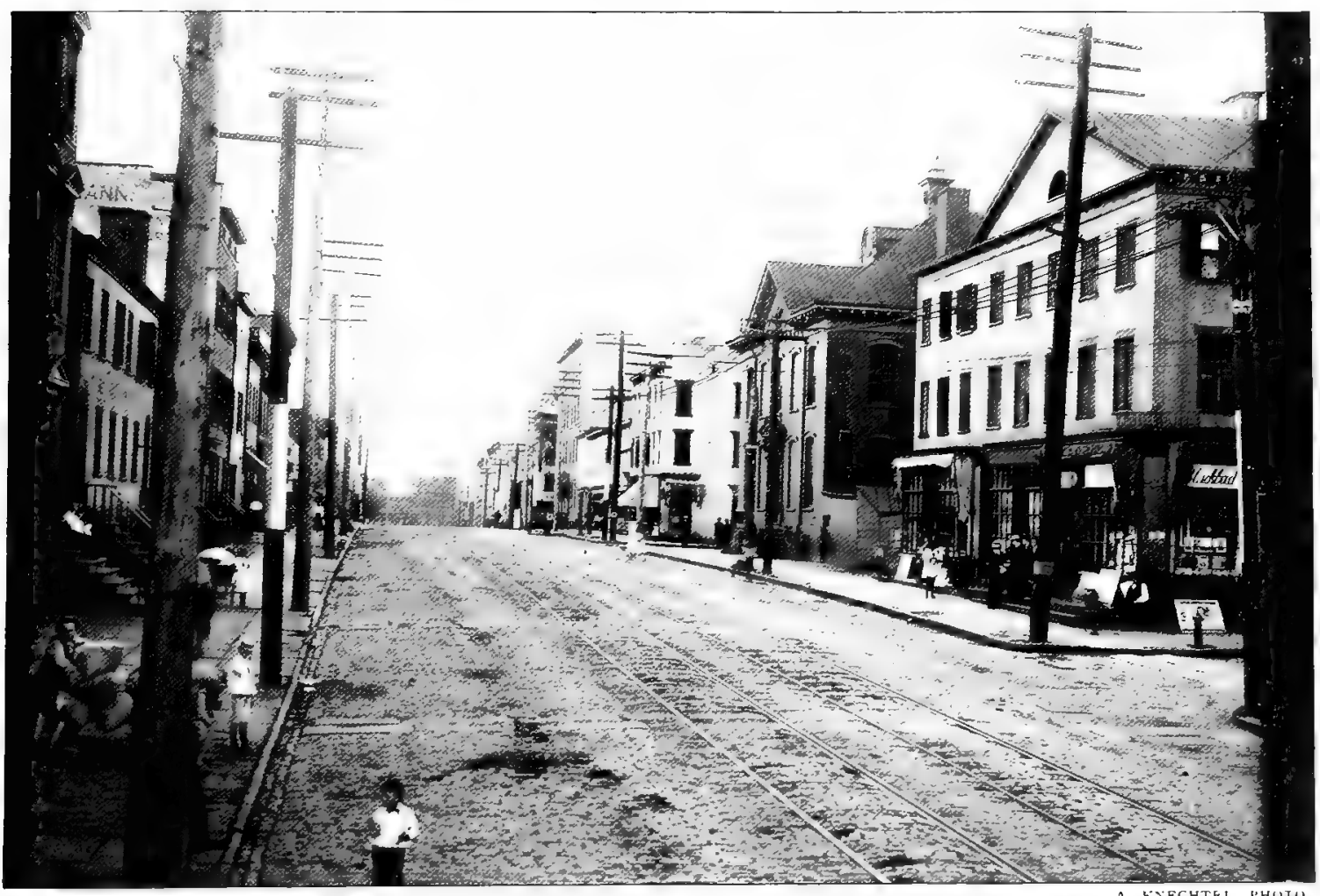

A TREELESS STREET. 

be done to the exclusion of foreign ones. Some of the common trees on our streets and highways, the Horse Chestnut, Ailanthus, and Lombardy Poplar for instance, are introduced species which at one time were regarded as foreigners. It is fair to assume that there are still others with beauty and useful qualities which would render them welcome and enable them in time to take a place among our common well-known trees.

\section{Undesirable Species.}

Some trees are omitted, not so much on account of doubtful qualities but because the list already offers ample opportunity for selection from the large number named. There are, doubtless, several other species which might be planted with satisfactory results, but many of them have defects which should be considered carefully before making a selection.

The Ash-leaved Maple, a short-lived tree, puts out its lower branches too near the ground to permit its use on streets. The Canoe Birch does the same, and if the lower branches were cut off the pyramidal form of the tree would be destroyed and its beauty greatly impaired. The Kentucky Coffee Tree is so unsightly in winter, resembling then a dead tree, that it is better omitted in street planting. especially as it will thrive only in good moist ground. The European Ash lasts but a few years in our climate, and is in no way superior to our American White Ash. The Sour Gum or Pepperidge is a beautiful tree in autumn, but it is too apt to fail in transplanting. The Mountain Ash and Flowering Dogwood are beautiful, but the bright red berries of the one and attractive flowers of the other invite injury; their proper place, if on a street or road, is inside the fence and in some dooryard. The Sycamore Maple has a fine appearance and dense shade, but with so many other Maples, it is hardly neęded; like the Copper Beech and Schwedler's Crimson-leafed Maple, its place is in the park or arboretum. The Yellow Wood is one of our neatest, prettiest trees, with cream-colored flowers that attract swarms of bees when in bloom; but it has low branches, and its wood is so brittle that the trunk is very apt to split downwards from where it first divides. The Paulownia, Koelreuteria, and other exotics, beautiful and attractive as they are, should be reserved for private grounds or secluded parkings where they can receive the care and attention which they always require. The Carolina Poplar, or Cottonwood, is often recommended because of its very rapid growth; but this tree sheds a downy, cottony tuft which clings to the clothing of passers-by, causing so much annoyance that, in many towns, 
orders were issued for its removal.* All of these species are pleasing in appearance, and each has some good quality to commend its use, but they should be reserved for lawns, dooryards and parks, where they will appear to better advantage than along the curbstones.

None of the evergreens have a place on the list, for they are of little use as shade trees. Most of them are forest trees, which, when growing in the open, assume a different habit, their lower limbs commencing at the ground. A row of White Pines, properly trimmed, might be used on a country road, and the Tamarack, or American Larch, looks well in the farmer's dooryard; but all evergreens require skill and great care in transplanting, and seem out of place in city streets. Many of them, however, are highly ornamental, and very useful for park and lawn purposes; and then there is the unquestionable advantage which evergreens have in winter, giving beauty to a roadside when all the other trees are bare.

\section{Destroctive Insects.}

Objection will probably be made to some of the species named because of their liability to injury from destructive insects. But if all such trees are to be thrown out, the choice will be narrowed down to a very few kinds, the excluded ones embracing many of our finest and most popular shade trees. Even then, there is no assurance that the remaining species, although free from insects hitherto, will continue in their immunity. The freedom of certain trees from insect blight is due largely to the fact that few have been planted, and that the pests find plenty of food in the other species. While it may not be possible to fully exterminate these borers and insects, or prevent entirely the injury from this source, the evil can be so controlled that their destructive work can be greatly minimized; and, as regards some species and insects, entirely obviated. It would seem that the better plan is to continue planting whatever species may be desirable, and, then, through intelli-

* The Common Council of Albany passed an ordinance in I87I, providing that "No person shall plant or maintain in the city of Albany any tree of the species commonly called the Cottonwood, and any person who shall maintain, or suffer to remain, after reasonable notice by the Street Department to remove such tree, shall be deemed guilty of a misdemeanor, and shall incur a penalty not exceeding ten dollars for each day such tree shall remain after notice to remove, or by imprisonment in the Albany County Penitentiary not exceeding three months, or both, in the discretion of the Court." Pursuant to this law all the Cottonwoods on the streets of Albany were cut down. The ordinance is still in force.

In other cities orders were issued for the removal of this species; but it does not appear that it was a penitentiary offense for an obstinate citizen to "maintain" his preference for a Cottonwood. 
gent methods and faithful work control the evil as far as possible. The potato bug was a formidable enemy at one time; but the farmers kept on planting and fighting until they succeeded in overcoming or controlling it. It has been demonstrated that by spraying trees, by using suitable emulsions and insecticides, and by gathering the cocoons the destructive work of insects can, for the most part, be prevented or, at least, controlled. The State Entomologist is ready at all times to furnish information and advice to any who need his assistance. With proper care and attention the trees can be protected; but, if this care and attention will not be given, the selection of the tree is of little importance.

\section{Rapidity of Growth.}

Trees have been described here as of rapid growth and slow growth. These are largely relative terms which, to some people, may convey but little meaning. They will be better understood when the growth rate of some of our well-known species is noted. Beginning with a three-inch sapling, the following named trees will, in twenty years, under favorable conditions, attain a diameter approximately as follows:

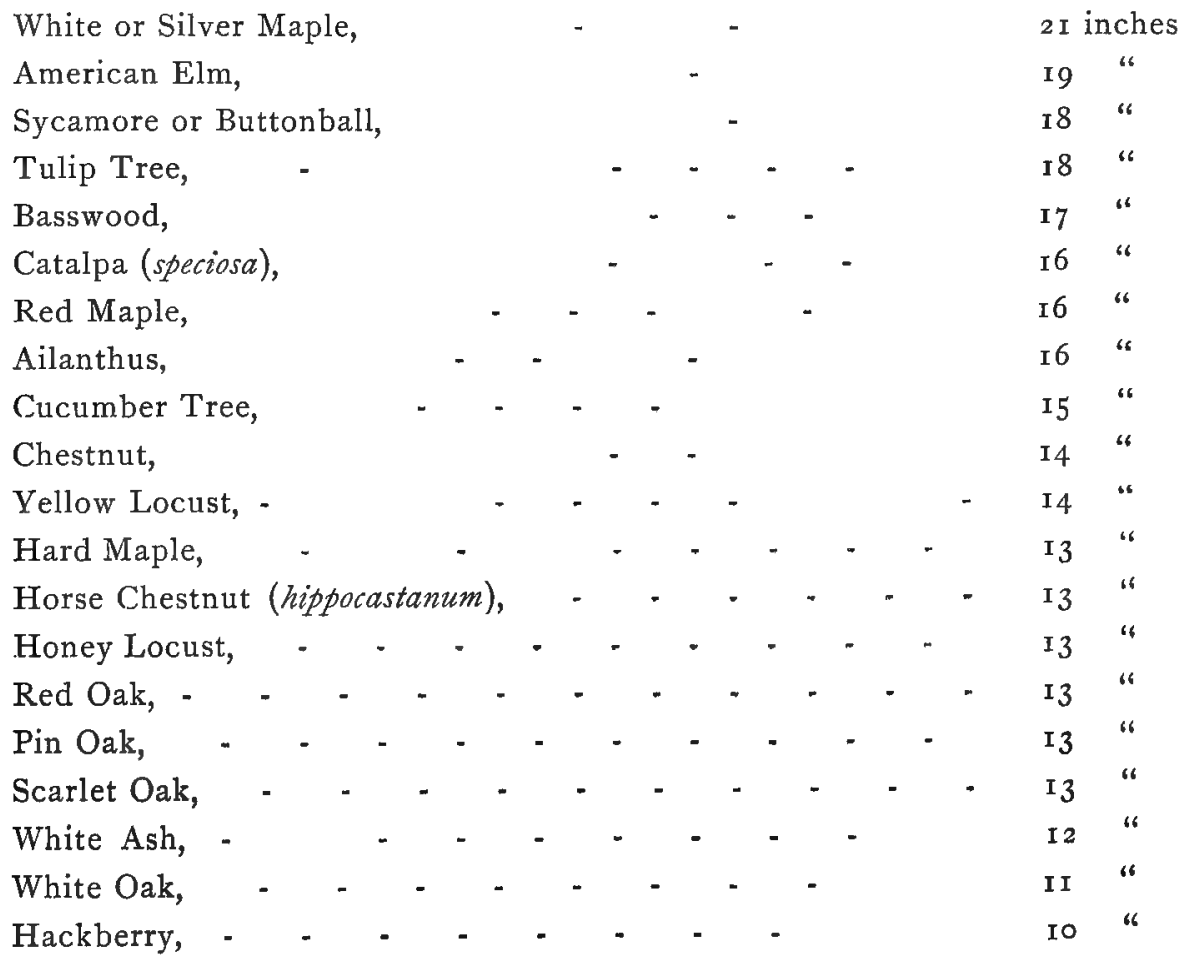

The height which each species may be expected to attain is omitted here, as it will assume the usual proportion to the diameter. 
Trees may be planted in the spring or fall, preferably in the spring before the buds open. If, through lack of information or experience, there should be a difficulty in determining what to plant it would be well to note the kinds that thrive best in the vicinity, and choose accordingly. Having decided on the species, the tree or trees should be ordered from some nursery, because, as a general thing, better results will be obtained. Nursery stock bears transplanting better than that from the woods; for the roots are not spread out so widely as those of forest trees which, by reason of poorer soil, are obliged to reach out further for nourishment, and, hence, sustain more injury when the tree is dug up. In size the plant should be from two to three inches in diameter near the ground, and from ten to twelve feet high. But little is gained by using larger ones, as the smaller trees soon overtake or pass them, and the larger the tree the greater the risk in transplanting. Maples, Elms and Lindens, however, may be used with larger diameters than other species. The Oak thrives better when the smaller sizes are planted.

Nursery trees cost from fifty cents to one dollar each, according to the size or scarcity, to which must be added the expense of freight and cartage. When ordered in large quantities a suitable deduction in price is made. But for villages and roads it may be more convenient and economical in some localities to obtain the young trees from the neighboring woods. In that case pains must be taken to select straight, thrifty specimens with clean, healthy bark, well-shaped top, and regular arrangement of branches.

\section{Transplanting.}

In digging up a young tree the roots should be preserved as far as practicable, the circular trench being at least six feet in diameter, or three feet from the stem in all directions. Any unnecessary breaking or wounding of the roots must be avoided, and all the slender rootlets should be secured as far as possible. The more earth that can be taken up with the roots the better. A solid lump is not necessary; but whatever soil clings to the roots shnuld be retained and not allowed to fall off through jolting or careless handling.

Having dug up the sapling, examine the roots carefully, cut off cleanly and smoothly with a sharp knife all the bruised or broken ones, cutting them back to the sound wood. Then these roots will not decay, and the new fibres or rootlets will grow quickly. If there is a long tap root it should be shortened to conform to the depth of the hole in which the tree is to stand. Do not allow the roots to be exposed to the sun or wind; cover them up immediately with damp straw or bags, or, dip them in liquid mud repeatedly until a thick coating is formed that will 

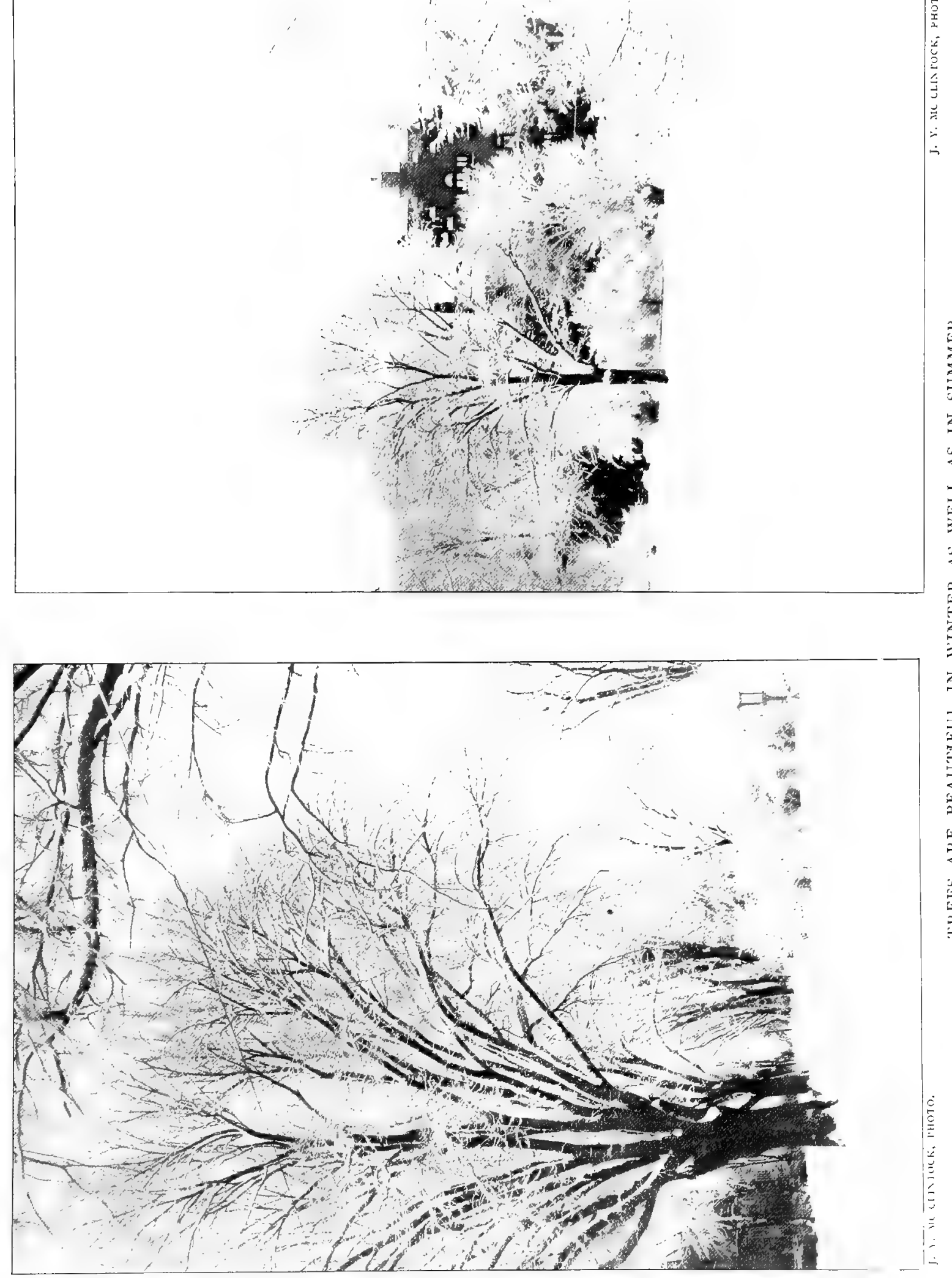

exclude the air, and keep them moist. If the fibrous roots become dry through lack of some such precaution the work will probably prove a failure.

The stem of the tree may be cut back from the top; but the frequent method of pruning forest saplings down to a bare pole is not advisable. It is better to allow three or four of the limbs to remain, selecting those which will give the best arrangement; and then, in cutting them back, leave one bud on each. This will make a better shaped tree in time. The severe pruning of the transplanted tree is necessary on account of the loss in its roots; the more roots are cut off the greater the amount of pruning needed.

There must be a new growth of root fibres before the young tree can support its foliage safely. The leaves of a healthy tree are nourished by the sap which is drawn from the roots as fast as needed; but if this tree is transplanted the supply is partially cut off until new roots and fibres are formed to replace those lost in transplanting. If, during this period, the leaves and branches are allowed to keep on draining the sap, they will exhaust the supply before the new roots are grown, and the tree will soon wither or die.

The natural character of the soil should always be carefully studied, for trees that thrive in one place may fail in others. Some species that attain their highest development in sandy soils will not live in any other; some that find a natural habitat in rich ground must have the same soil conditions in order to fulfill the expectations of the planter; while others that thrive in low wet places will eke out but a scanty existence if planted on high, dry lands. The artificially prepared earth with which the hole is filled cannot be depended on to permanently counteract the unfavorable influence of adjacent soil.

The holes should be dug before the trees arrive, and the earth for filling should also be in readiness. The holes must be large enough so that the roots can be spread out in their natural position without cramping them in the least. It is well to dig them so that there will be a foot or more of additional space on all sides, and of ample depth. This is especially necessary in poor soil. In digging throw the top soil to one side and cart away the poorer earth which came from the lower part of the hole. In place of the latter use a rich soil, one-fourth manure, thoroughly mixed, worked until it is fine and free from lumps, sods or stones. Use no manure unless it is thoroughly mixed with earth; if it touches the roots it will burn or rot them. Where there is a good soil of sufficient depth, well adapted to the natural requirements of the species to be planted, much more may not be necessary aside from making the hole large enough so that all the roots can be spread out freely without any cramping or twisting. 
In setting the tree two men are required. One is needed to hold the tree upright; the other will be fully occupied shoveling in the earth and then working it with his hands under and closely around the roots and fibrous branches. The earth must be thrown in slowly and in small quantities at a time; as fast as thrown in it should be rammed or trodden down until there can be no air spaces, and until every rootlet is brought in close contact with the soil. No water should be used; it is not necessary. If dashed into the hole, as sometimes done, it is apt to wash the earth away from the roots in places, leaving air holes. If water is used it is better to sprinkle the sides and bottom of the hole before planting; also the surface of the ground after the work is done. Frequent and thorough ramming is necessary. Young trees that have wilted and seem to be dying have been restored quickly to life and vigor by using heavy rammers that brought the loose earth in contact with the roots again.

In addition to a rich soil it is highly essential that there should be a good drainage. Moisture is beneficial; but if water collects around the roots the tree will die. Clay is impervious to water, and if a stratum of this soil is found near the bottom of the hole, drainage must be provided by digging a passage through $\cdot$ it, building a stone drain, or sinking a very deep hole which can be filled to a proper height with broken rock, gravel, or ashes.

A tree should be set at the same depth that it formerly occupied; but when the hole has been filled the surface may be rounded up sufficiently to allow for the settling of the earth. If exposed to strong winds the young tree should be "staked," and fastened to the stakes by strips of cloth or any appliance that will not injure the bark. In setting out a forest tree it may be well to place it in the same position as to points of compass which it originally occupied. A cloudy day is better for planting than one when the sun shines clear and hot.

After the tree is planted the ground should be covered with a mulch, three or four inches deep, of straw, hay, or manure. The latter will serve, also, as a fertilizer. If nothing else is done, the loose stones that came out of the hole can be thrown back on the ground to keep it moist. For a few years the surface of the ground around the tree should be loosened each season to prevent it from becoming dry and hard. Grass and weeds should be kept out, as they weaken the growth of the young trees.

Although spring is the better time for transplanting, it may be desirable under some circumstances where nursery trees are used to order them in the fall, and then heel them in until spring. "Heeling in" is temporary planting in a trench, or merely placing them in the ground and covering the roots with a thick layer of 
closely-packed soil to exclude the air. They can be placed closely together, and should be set in a slanting position with the tops inclined away from the prevailing winds. Heeling is also resorted to when nursery stock arrives before preparation has been made for planting.

"This method is favored by some because, when trees are taken up in the spring the "callus" which forms on the mutilated roots will not put out its white, hairylike fibres in time to furnish sap for the early buds that are dependent on them; but when taken up in the fall and heeled in, the callus forms during the winter, and is ready with its new fibrous growth to furnish nourishment as soon as transplanted.

\section{Proning.}

As trees grow larger and older they require pruning occasionally to remove dead limbs, to improve their shape, and, in the case of very old trees, to restore them to vigor. This work should not be entrusted to ignorant, inexperienced persons, as is too often the case. Men of this class frequent our cities, and solicit employment as tree pruners. With glib tongues they describe the defects, real or otherwise, in street or lawn trees, and obtain permission to do some work. As a result, beautiful specimens have been disfigured or irremediably injured. Whenever any extensive pruning becomes necessary proper means should be taken to secure the services of skilful, experienced men who have testimonials or recommendations signed by some competent authority in such matters.

Some of our best shade trees can be improved in appearance occasionally by trimming or cutting back in order to correct irregularities, or to attain some form better adapted to the situation. Such work can be done without injury to the trees; but it can be undertaken safely only by a skilful, professional tree pruner.

When a tree becomes "stag headed" by dying at the top the dead limbs thus exposed should be cut off, and the rest of the tree trimmed somewhat to correct the irregularity in its general outline. Old trees that have become bare and unsightly may often be restored to temporary vigor and clothed with foliage by severe prun. ing; but any extensive trimming of this kind is justifiable only when it is neces. sary to prolong the life of a tree which otherwise would soon die. Some species, Hard Maple for instance, along a walk or driveway can be made more serviceable under certain conditions by increasing their height, which is accomplished by cutting off a few of their lower limbs. But this operation requires careful, intelli. gent work, and should not be resorted to unless there are special reasons for it. 
Pruning is necessary at times the same as surgery, and is successful only when skilfully done.

The best time for pruning is in the fall, soon after the leaves have dropped. Trees may be pruned in the spring with safety, but it must be done early and before there is any swelling of the buds. Soft maples will stand a moderate trimming during the sap season.

Whenever a branch is removed, whether a dead or a live one, it must be cut off close to and even with the trunk, no matter how large the wound. The new wood and bark will then, in time, cover the denuded space. The process by which this recovery is accomplished is well explained in Des Cars' treatise on tree pruning, a copy of which should be in the possession of every one who owns or has charge of trees. If a branch is not cut off close to the trunk, the projecting stub soon decays, its bark falls off, and the stump remains "like a plug of decaying wood driven into the trunk," from which the rotten mass extends rapidly to the heart of the tree.*

In removing a large branch, enough of the outer portion should be first sawed off to prevent its weight from splitting the wood downward beyond the point where the final cut is to be made. All wounds made in pruning should be covered with coal tar or white lead to exclude the air from the raw surface. Coal or gas tar, by penetrating the pores of the wood, acts as a preservative, and at the same time prevents the inroads of fungi and insects. The painting of the exposed surface is more efficacious if done when the sap has ceased its flow, for then the material applied will adhere more readily to the wood.

Nearly two hundred and fifty years ago John Evelyn $\uparrow$ in discussing the subject of pruning says: "Putatio, or Pruning, is the purgation of trees in general from what is superfluous. The antients found such benefit in pruning that they feigned a Goddess presided over it, as Arnobius tells us: and, in truth, it is in the discreet performance of this work that the improvement of our timber and woods does as much consist as in anything whatsoever. It is a misery to see how our fairest trees are defaced and mangled by unskillful wood-men and mischievous borderers, who go always armed with short hand-bills, hacking and chopping off all that comes in their way; by which our trees are made full of knots, stubs, boils, cankers, and deformed bunches, to their utter destruction. As much to be reprehended are those who

* A treatise on Pruning Forest and Ornamental Trees. By A. Des Cars. Translated from French, with an introduction by Charles S. Sargent, Professor of Arboriculture in Harvard College. Published by the Massachusetts Society for the Promotion of Agriculture. Boston. I894.

$\lceil$ Silva, A Discour'se of Forest Trees and the Propagation of Timber. By John Evelyn, Esq., F. R. S. Written in 1662.2 Vols. 4 to. $802 \mathrm{pP}$. 



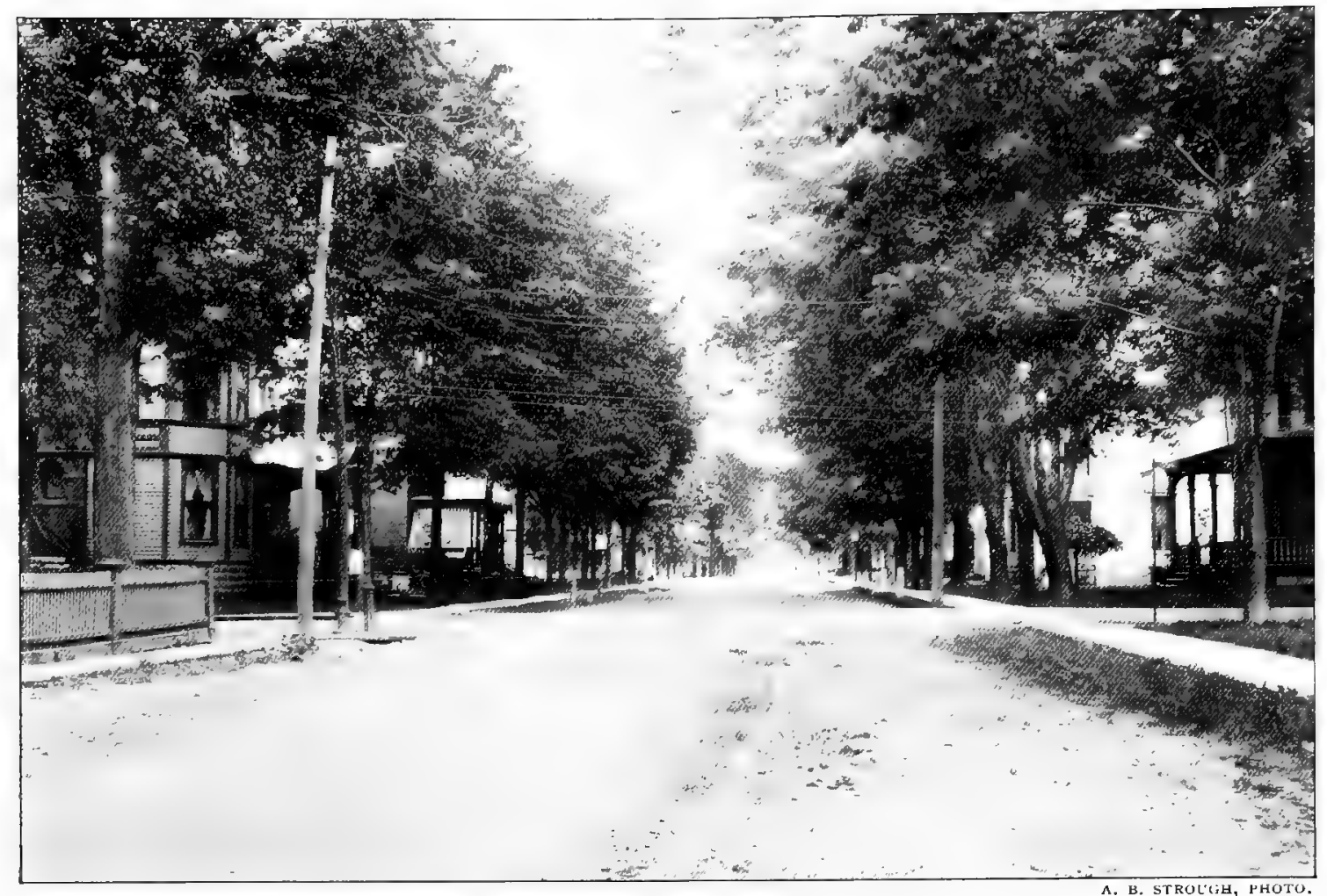

S'lREET' WITH TREES PLANTED INSIDE THE WALK. - WATERTOWN, N. Y.

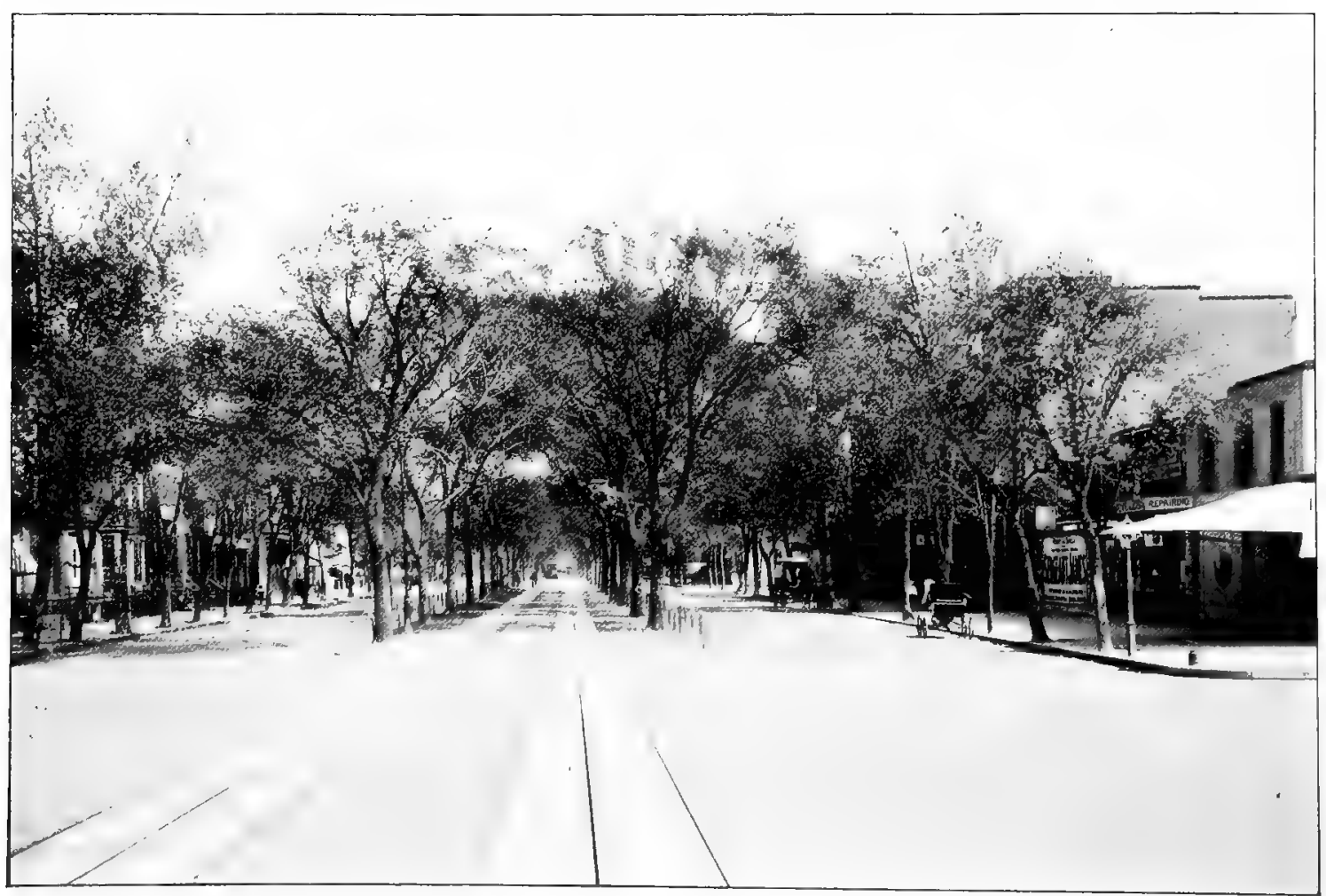

A. G. VAKELA, SHOTO

MAPLES AND EIMS. - NEW YORK AVENUE, WASHINGTON, D. C. 
either begin this work at unseasonable times, or so maim the poor branches that, either out of laziness, or want of skill, they leave most of them stubs, and instead of cutting the arms and branches close to the bole, hack them off a foot or two from the body of the tree, by which means they become hollow and rotten, and are so many conduits to receive the rain and the weather, which conveys the wet to the very matrix and heart, deforming the whole tree with many ugly botches which shortens its life and utterly mars the timber." He also cautions the pruner "to cut smooth and sloping upwards, if upright boughs, otherwise downwards; and be sure to emplaster great wounds to keep out the wet, and hasten the covering of the bark: besides, for interlucation, remove exuberant branches, et spissae nemorum coma, where the boughs grow too thick and are cumbersome, to let in the sun and air."

When one reads the old writings of this silvan worthy it would seem that there is nothing new to be said on trees or forestry, and that whatever one might write on the subject it would appear very much like plagiarism.

\section{Arrangement of Trees on Streets.}

In street planting the trees should be placed with reference to the room they will need when fully grown, rather than with reference to the lot bounderies; other. wise, there will be irregularity, overcrowding and unoccupied spaces. The average city lot is too narrow to permit a tree on each, and so the proper spacing on a block must be determined irrespective of the wishes of the property owners, each of whom might want a tree in front of his house. If a block is fully planted, the trees on one side of the street should stand opposite the spaces on the other side. Planting at half distance, with the intention of removing every other tree in time, is sometimes done in order to obtain more shade at the start. But this plan is an objectionable one; the intermediate trees are seldom removed, and, in their crowded condition, become ill-shaped and undersized. The arrangement is a doubtful expedient, even if the superfluous ones are removed at the proper time; for while the trees are small they afford neither beauty nor shade, no matter how closely they were planted. The only case in which intervals might be filled with advantage is in a row of old trees that have passed maturity and are nearing their end. In such a case time can be saved by planting young ones in the spaces; for when the old decaying trees fall the young ones will be well along toward replacing them. On residential streets where the houses stand well back from the fence line, with lawns or wide yards in front, the trees should not be placed at the curb, but inside the walk where they will be free from injury, obtain more moisture, and afford an equally good shade. 
An avenue should be planted throughout its entire length with the same species. or, at least, for several blocks. By using one kind on a street a stately architectural effect is obtained that will always be pleasing and impressive. While variety may be desirable for its educational tendency, it should not be permitted because of the irregular, unsightly appearance caused by trees of different sizes and shapes. Lamp posts, as well as trees, are deemed ornamental by many people; but no one would even think of erecting posts of different heights, size and appearance on the same street. The advantages of a variety are better secured by planting different species on different streets. A pleasing and advisable variation of this rule has been suggested by Mr. Lewis Collins, Secretary of the Brooklyn Tree-Planting Society that at the intersection of wide streets an Elm should be placed at each corner, an . arrangement which would add rather than detract from the architectural appearance. A change of trees may be allowed on rural driveways where the irregularity of the scenery will better permit such an arrangement; but, even then, it is better to avoid abrupt, repeated changes by planting the same species for a considerable distance.

Although every residential street should be well shaded, an exception may be made in commercial thoroughfares. The latter, in some instances, might be planted and thus rendered more attractive without interfering with business operations. In European cities the commercial streets often present a pleasing picture on account of the foliage which also hides from view the marks of trade, while in Holland the wharves in some places are shaded by tall trees that mingle their branches and leaves with the yard arms and rigging of vessels unloading at the docks close by.

\section{Protection of Trees.}

In towns and cities the trunk of every tree, whether young or old, newly planted or of full growth, should be enclosed to a proper height in wire netting of a small mesh. Unless this is done, or some similar precaution taken, it is not worth while to plant. The necessity for some such protection is readily apparent on examining trees from the curbstone side, and observing the large number on which the bark has been gnawed by horses. There is a feeling akin to pity when one notes the patient, repeated efforts of the tree to repair the injury - how it tries each year to cover the wound with new wood and bark, only to have it torn and widened by some fresh attack. It is wasted time to discuss punitive measures as a remedy for this evil. The horse is not to blame; and any law for the prosecution of the driver would be practically inoperative. A more sensible way would be to protect the tree by some of the simple, inexpensive devices which are available. All of the trees in Washington are protected by wire screens, of a large mesh, wrapped around the 

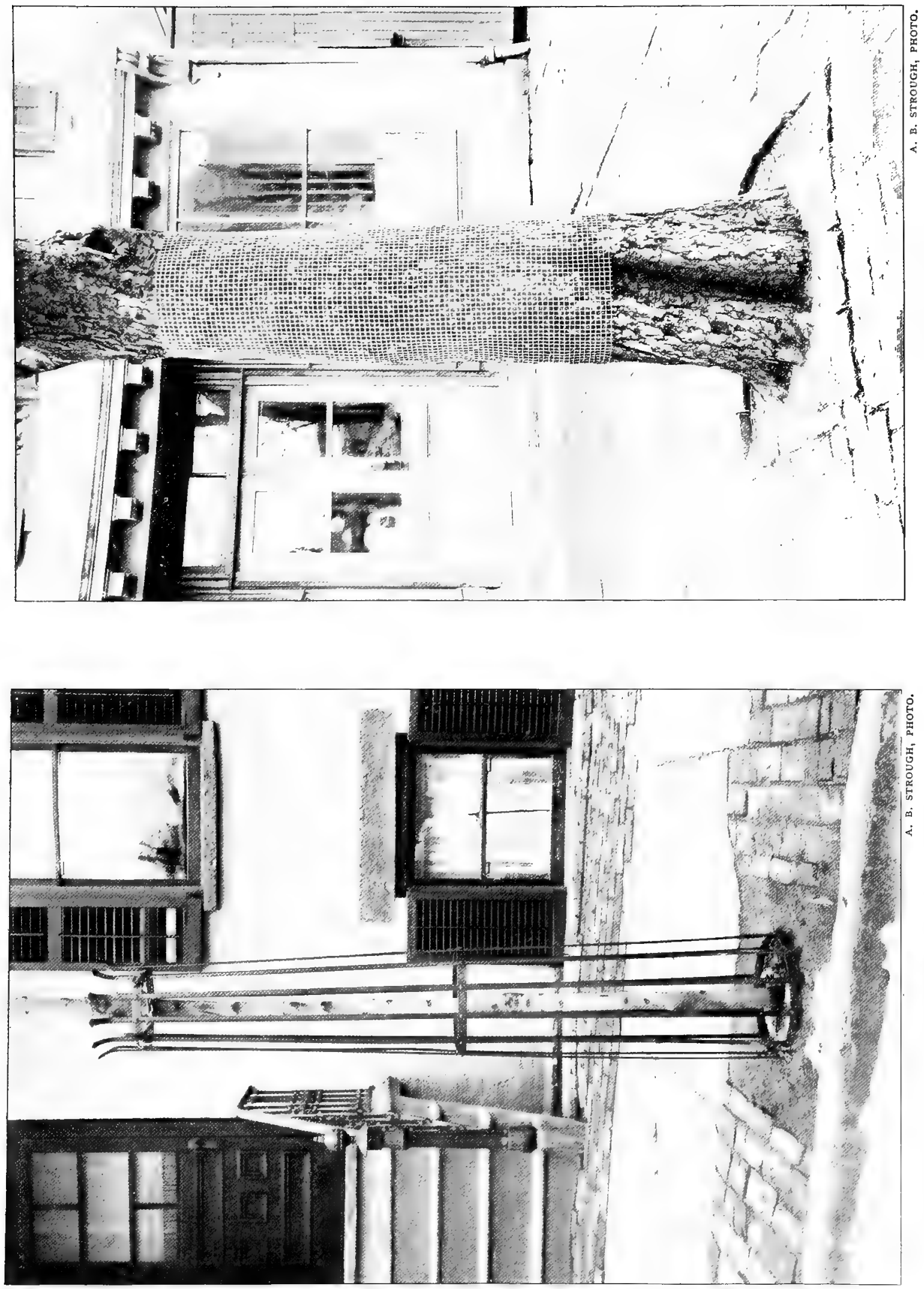

trunk. But this, in turn, will never be done until the care of the trees devolves upon the city authorities - or a tree-planting society invested with necessary powers. The man in a rented house will not invest a cent to protect the tree in front of his residence, and the landlord cares nothing about it so long as he gets his rent.

The erection of electric wires for telephone service, trolley lines and illuminating purposes, is a prolific source of injury. It is a disputed question whether electricity itself does much harm; in fact, a mild current may be beneficial to trees as well as men. Prof. Stone states that, as shown by experiments, the alternating current is less disastrous to plant life than the direct current, and that either, when used at a certain strength, will accelerate growth and strength.* The injury from the current is mostly local, being confined to points of contact; and this can be largely prevented by a complete insulation of the wires. But the mutilation or destruction of trees caused in the stringing of the wires is another matter. This evil can be prevented by the village or town authorities, unless a right of way has been granted which gives the railroad, telephone, or electric light company permission to remove any obstruction that interferes with the erection of its poles and wires.

\section{Protection from Insect's.}

Protection from insects requires constant care and watchfulness. As the householder, generally, has only a few trees to look after, he can, with proper care and diligence, effectually check any insect pest before serious damage is inflicted. But neglect and carelessness on his part may result in the loss of his trees. At the first sign of danger expert advice should be sought for as to the proper remedies and methods to be employed. Where a large number of trees on a street or lawn are attacked by insects a spraying with poisonous mixtures must be resorted to.

Spraying is done with a duplex pump operated by a steam or gasoline engine, the machinery and tank being placed in a light spring wagon, and hauled with one horse from place to place. With 95 pounds pressure, or thereabouts, trees eighty feet high can be sprayed; and by using ladders, and hose with a spray nozzle, the under side of the leaves can be thoroughly drenched. This apparatus is used on streets and in public parks, or wherever a large number of trees require treatment. The citizen who is mostly concerned with the trees of his own street front or lawn can obtain satisfactory results from a hand pump with plenty of hose. To be effcctive the spraying must be done at the time the insects begin to feed.

\footnotetext{
* Prof. George E. Stone, Hatch Experiment Station, Amherst, Mass. Dangers to Shade Trees; a paper read at a meeting of the Massachusetts Forestry Association, held in Worcester, Mass., Nov. I9, IgO2.
} 
Various mixtures have been tried - Paris green, London purple, and arsenate of lead - each with good effect. Prof. Felt, State Entomologist, recommends the following preparation as an effective one against the ravages of leaf-devouring species: Dissolve eleven ounces of acetate of lead (sugar of lead) in four quarts of water in a wooden pail, and four ounces of arsenate of soda (50\% purity) in two quarts of water in another wooden pail. As the acetate of lead dissolves rather slowly in cold water, the process can be hastened by using warm water. Pour the resulting solution into the spraying tank, which should contain about eighty gallons of water. Where a contact insecticide becomes necessary, as in the case with sucking or biting insects, aphids, plant lice, scale pests, etc., he advises the use of this emulsion: Dissolve one-half pound of hard soap in one gallon of boiling water, and, while still hot, add two gallons of kerosene; emulsify by passing rapidly through a force pump till it assumes a uniform creamy consistency and the oil does not separate. Dilute this with ten parts of water before using. In limestone regions use the sour milk emulsion, composed of one gallon of sour milk and two gallons of kerosene ; emulsify and dilute as described before.

The cost of spraying depends necessarily on the extent of the work - the larger the number of trees, the less will be the average expense. In 1898 the cost of spraying Elms in Albany was about fifteen cents per tree for each application; and in I900, with a more expensive apparatus and men working under the eight-hour law, it cost twenty-two cents. In Troy, trees were sprayed by contract at twenty-three cents for each spraying, a much higher price being charged for single or scattering trees. In New Brunswick, N. J., a contract for the season, including treatment as often as needed, was made at one dollar per tree. The expense, whatever it may be, is insignificant as compared with the value of the trees.

A simple and effective check on certain insects - the white-marked tussock moth for instance - consists in destroying the egg masses. In I894 the school children of Rochester, N. Y., stimulated by liberal cash prizes, gathered $8,800,200$ cocoons of this insect, and thoroughly eradicated the pest in that locality. Of the successful scholars, 65 received a $\$ 10$ gold piece each, while others received smaller awards. The prizes, which were offered and paid by the Genesee Valley Forestry Association, amounted to much more than was expected; but the money was well expended and cheerfully. paid, as the city saved its shade trees and secured immunity from further ravages of a destructive insect.

The limits of this article will hardly permit of a description of the various insects and borers that infest our shade trees; or a recital of the many formulas for insecticides which have proved effective in checking their ravages. 


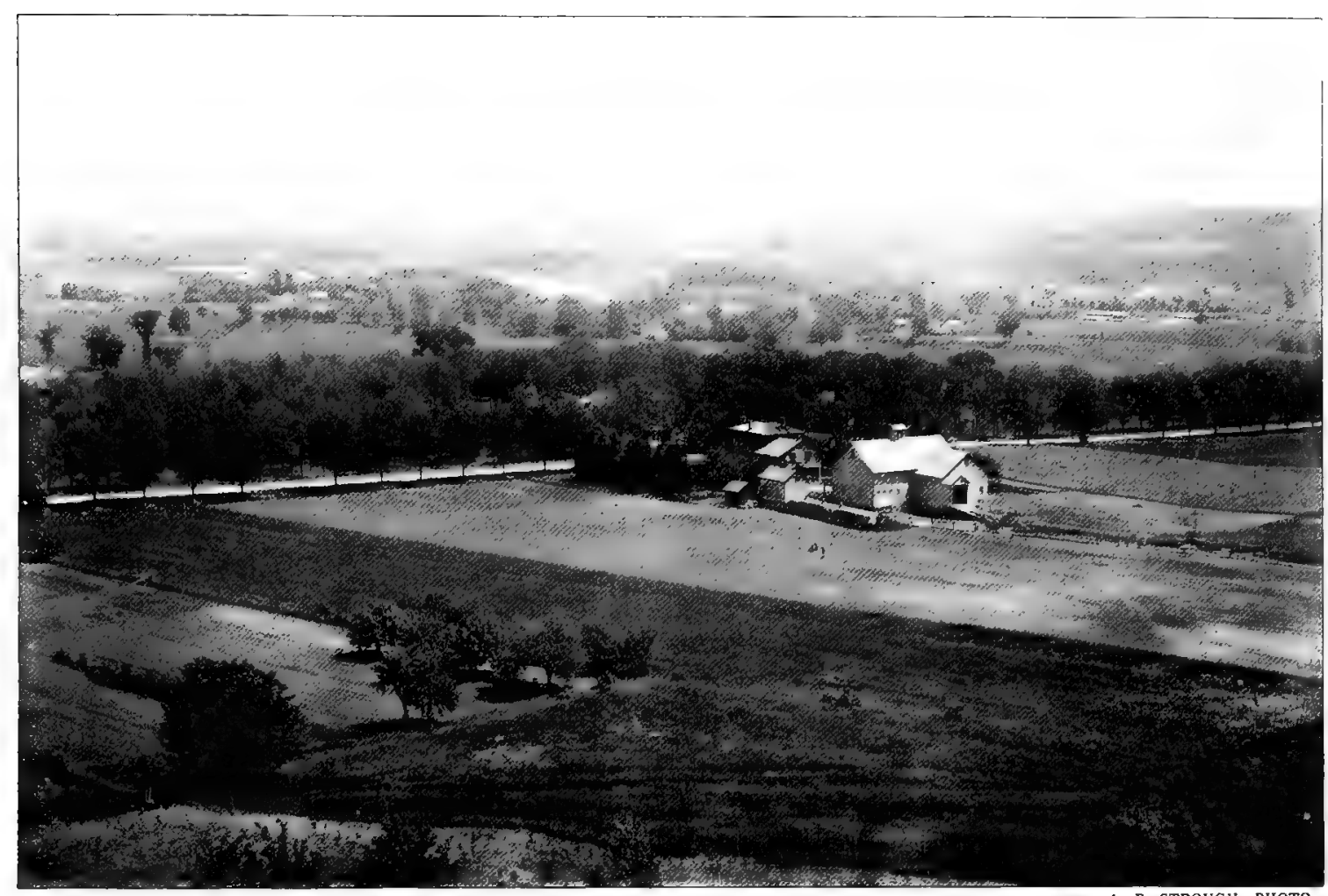

A WELI,PLANTED HIGHWAV.-JEFFERSON COUNTY, N. Y.

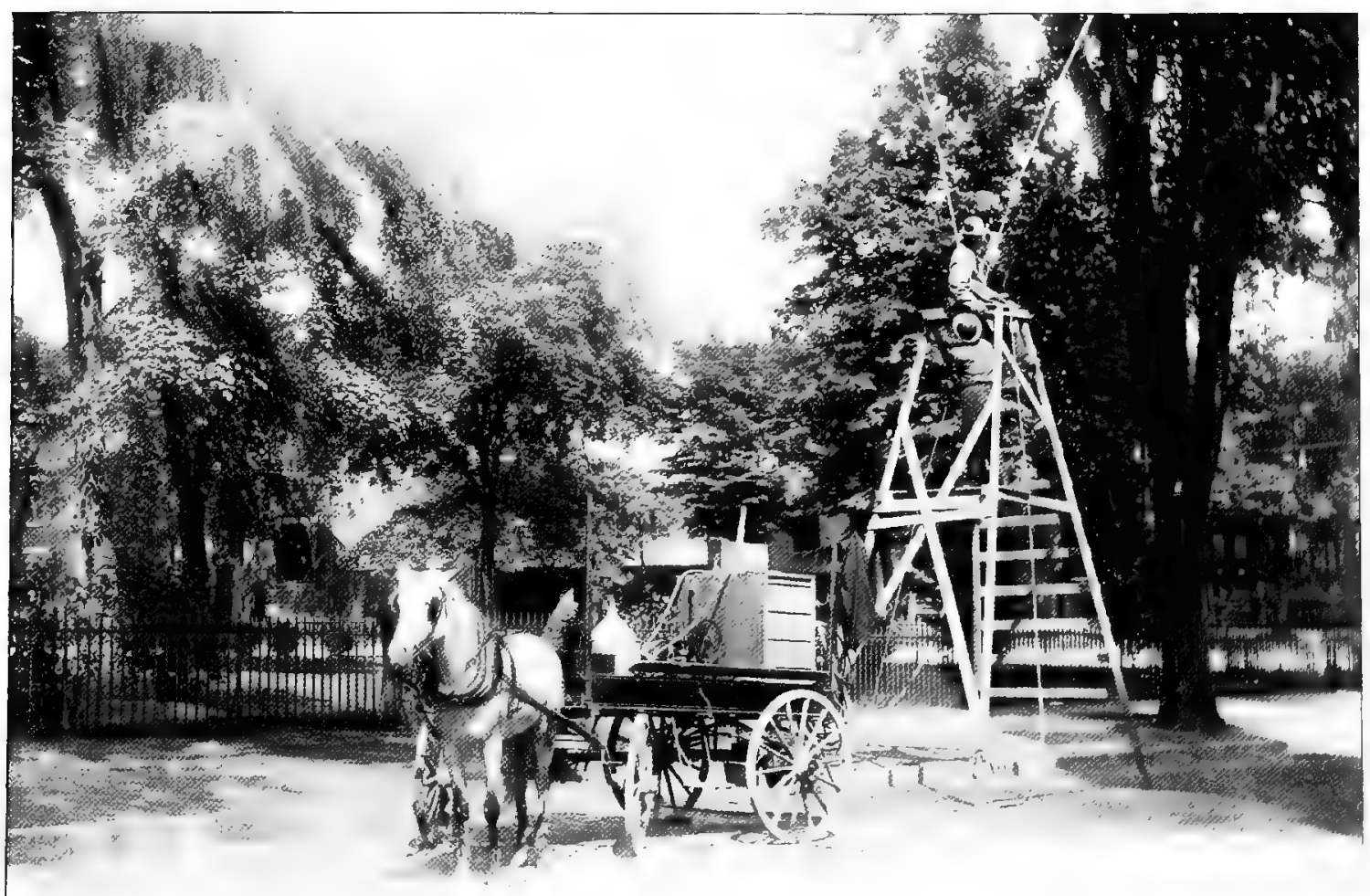

PORTABLE ENGINE AND PUMP FOR SPRAYING TREES, - ALBANY, N. Y. 

The insects which kill or injure shade trees may be divided into three general classes: (I) the leaf-devouring or masticating species; (2) the leaf-piercing, nonmasticating, or sucking insects; (3) the borers. Prof. Felt, in the previous reports* of the Forest Commission, gives a minute description of the tussock moth, forest tent caterpillar, leopard moth, maple borer, maple tree pruner, cottony scale insect, elm leaf beetle, bag worm, fall web worm, spiny elm caterpillar, elm borer, elm bark louse, and elm snout beetle. These descriptions are accompanied by colored illustrations showing the insects at each stage of transformation; also, formulas for insecticides, spraying mixtures, and emulsions, together with the details of other methods that have proved effective.

\section{Monicipal Controt.}

In towns where there are no well-organized tree-planting or village improvement societies the planting of street trees and their subsequent care should devolve on the city or village government, preferably, if in a city, on the park commissioners, as the officials in that department would be better qualified for the work, farther removed from political influences, and would be more apt to have the long tenure of office necessary to the proper management of the work. The planting and care of street trees belongs to the city government as much as street paving. Under the stimulus of local improvement societies individuals often do some planting; but when they sell their property or move away the trees are apt to be neglected. Moreover, it is difficult without municipal control to secure the concerted action necessary for planting a street its entire length with uniform and properly selected species.

Then, again, under the management of a special city department, properly supplied with funds, the spraying of trees and suppression of insect pests can be successfully accomplished; but it is doubtful if our trees can be preserved from this evil through the partial and disconnected efforts of individuals. As in Washington and Paris, every city should establish nurseries, supported by municipal appropriations, in which the various species best adapted to street planting can be propagated and grown with special reference to such use.

In some of our cities - New York and Brooklyn for instance - valuable and effective work has been accomplished by tree-planting societies; and their intelli-

* Insects Injurious to Shade Trees. E. P. Felt, D. Sc., State Entomologist. Fourth Annual Report, Forest, Fish and Game Commission, Albany. 18g8. Also, Insects Injurious to Elm Trees, by same author. Fifth Annual Report of Commission, 18g9. See, also, Prof. A. S. Packard, Fifth Report of the U. S. Entomological Commission, pp. 3I-47. Washington. I8go. 
gent efforts should receive, in some form or another, substantial recognition from the city government. While there may be legal objections to conferring municipal powers on individuals or associations, liberal appropriations might, with good precedent, be made for the benefit of a tree-planting society to enable it to carry on its work. Actuated by disinterested enthusiasm, and provided with funds for the employment of competent men, the society would do as good and intelligent work as any park commission, and, under certain circumstances, secure better results.

People who question the advisability of planting shade trees in cities rehearse the old story about the injurious effects of smoke, dust, and pavements, and then point to some sickly, deformed specimens in proof of their argument. But these unfortunate trees are the result of poor selection, bad planting, and neglect; and the blame should not be laid elsewhere. Asphalt pavement, though impervious to rain, will not prevent trees from obtaining moisture. On the other hand, it prevents evaporation; the earth beneath it is always damp, for there is still a supply of water from adjoining areas and small underground courses. For years the street trees of Washington and Paris have grown and flourished on the asphalt pavement of those cities.

It must be conceded, however, that asphalt or other impervious pavements lessen greatly the supply of moisture and prevent a sufficient aeration of the roots. To obviate this unfavorable condition as far as possible the flagging on the sidewalks should be cut out around the tree-leaving a circular space as large as the situation will permit - to facilitate artificial watering, to enable more of the rainfall to reach the roots, and to allow a frequent loosening of the earth at the surface. On narrow sidewalks this opening in the flagging should be in the form of an oblong rectangle in which the longest sides are parallel with the curbstone, as a larger space can thus be obtained without encroaching on the pathway. A still better plan would be to lay the flagging to the tree line only, leaving a strip of ground next the curbing, covered with gravel. The intervals between the trees are not used by people walking along the street. A slight slope in the surrounding fiagstones - not enough to interfere with walking - will increase the area of drainage and amount of moisture received, and a portion of the water that falls on the house roofs can also be conducted in proper quantity from the eaves-troughs and leaders to the roots by conduits laid beneath the flagstones. Where there is an asphalt pavement, openings protected by iron gratings should be left in the gutter opposite each tree, through which water will find its way at every shower, or when the gutters are flushed from a hydrant.

Another unfavorable condition caused by a tight pavement is the prevention of 


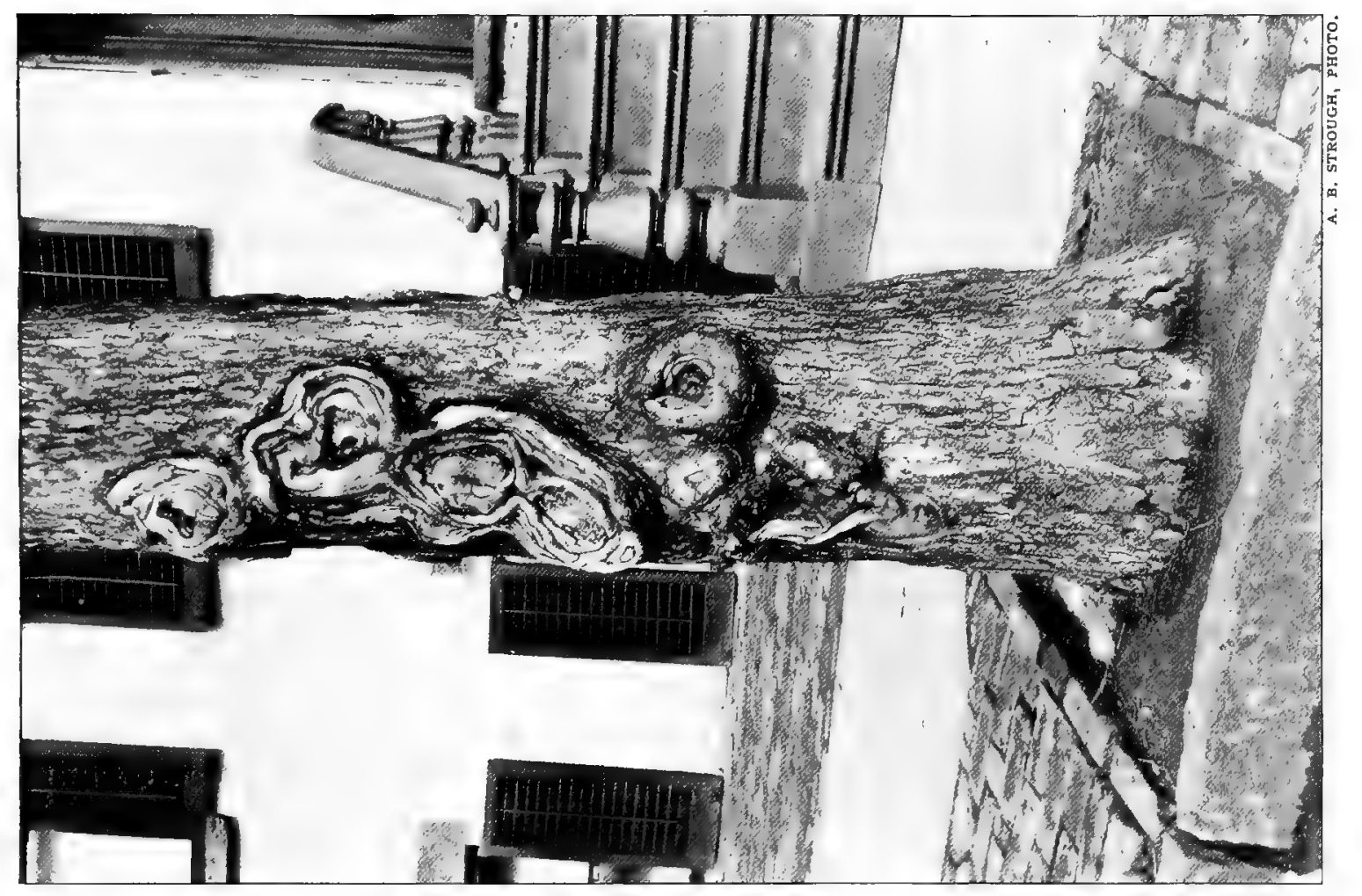

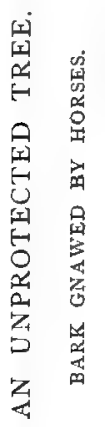

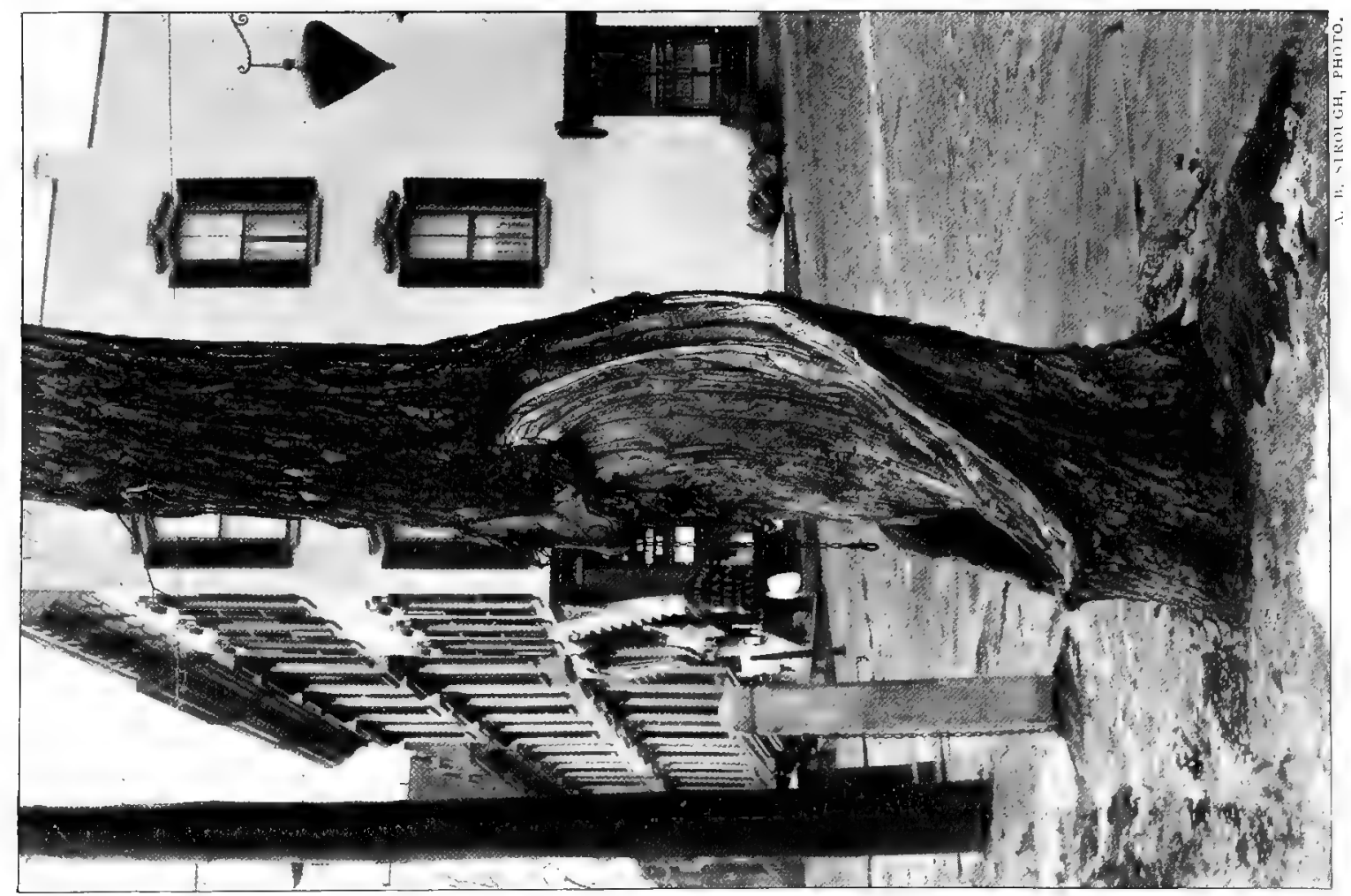



a proper aeration of the roots. This can be remedied to some small extent by the openings left in the flagging at the base of the trunk. But this affords only a partial remedy at the best, and so we cannot expect that a city tree on a closely paved street and sidewalk will develop the same thrifty growth and appearance as if it stood on a village street where the ground around it was exposed to air and sunlight.

People who believe in the efficacy of fertilizers in promoting tree growth are apt to consider the planting of paved streets a doubtful undertaking because there is no opportunity to enrich or cultivate the ground. But such discouragement does not seem to be based on sufficient reasons. Fertilizing material is beneficial to surface crops, but it can exert but little influence on roots that pentrate deeply in the earth, and which must draw their sustenance from the lower strata found there, good or bad as the case may be.

In many city streets the ground presents unnatural and unfavorable conditions. The surface has been cut down extensively by grading or blasting, which leaves exposed only the sterile earth of the lower strata; or a depression has been filled, in which case the planting must be done on "made ground" composed of ashes, street litter, old tinware, and all the other kinds of rubbish which are dumped in such places by the street cleaning bureau. Such conditions, however, should not be considered as a deterrent in planting; but they demand a more thoughtful study of the situation, with some additional effort in providing larger holes and an ample supply of fertile soil.

While smoke and dust undoubtedly are injurious to some species, leakage from gas mains has caused by far the greatest destruction of trees in city and village streets. No matter how hardy the species, how well it is planted, or how carefully it is fostered, if the ground becomes saturated with illuminating gas the tree is doomed. It may be assumed that a gas company will, in its own interest, endeavor to prevent any leakage in its mains. But the work of finding and stopping a small leak may cost more than the loss of the gas; and it is the small leak, when near a tree, that does the mischief.

A frequent source of injury is the unnecessary mutilation of the larger roots by laborers employed in digging the ditches for gas or water mains. In most cases this can be avoided by the exercise of some care and a slight expenditure of time, which should be insisted upon by the city authorities.

Let every citizen who finds enjoyment in well-shaded streets make an effort to procure the passage of a city ordinance placing the entire control of the trees of his town in the hands of a tree-planting society, or the park department, or some special commission, and use his influence, also, to see that ample funds are annually appropriated by the municipal or village government to carry on the work. 


\section{L.e̛gistation.}

John Evelyn said that men seldom plant trees till they begin to be wise; and so it may be well to note what the wise men in the Legislatures of various States have decreed as to tree planting on streets and highways. The Highway Law of New York has already been quoted. In other States the laws relating to tree planting are in part as follows:

\section{MASSACHUSETTS.}

Chapter 196, Laws of I890. Section I. The mayor and aldermen of cities and selectmen of towns are authorized to designate and preserve trees in highways for ornament and shade, not less than one tree in every thirty-three feet and of one inch or more.

Sec. 2. Provides for marking the trees selected.

Sec. 3. Provides that whoever injures, defaces or destroys any designated tree shall forfeit not less than five nor more than one hundred dollars.

Chap. 330, Laws of 1899 , Sec. I. Every town shall at its annual meeting for the election of town officers elect a tree warden, who shall serve for one year and until his successor is elected and qualified. He may appoint such number of deputy tree wardens as he deems expedient, and may at any time remove them from office. $\mathrm{He}$ and his deputies shall receive such compensation for their services as the town may determine, and, in default of such determination, as the selectmen may prescribe. He shall have the care and control of all the public shade trees in the town, except those in public parks or open places under the jurisdiction of Park Commissioners, and of these also he shall take the care and control if so requested in writing by the Park Commissioners. He shall expend all funds appropriated for the setting out and maintenance of such trees. He may prescribe such regulations for the care and preservation of such trees, enforced by suitable fines, not exceeding twenty dollars in any one case, as he may deem just and expedient; and such regulations, when approved by the selectmen and posted in two or more public places in the town, shall have the force and effect of town by-laws. It shall be his duty to enforce all provisions of law for the preservation of such trees.

Sec. 2. Towns may appropriate annually a sum of money not exceeding in the aggregate fifty cents for each ratable poll in the preceding year, to be expended by the tree warden in planting shade trees in the public ways; or, if he deems it expedient, upon adjoining land, at a distance not exceeding twenty feet from said public ways, for the purpose of shading or ornamenting the same; provided, however, that the written consent of the owner of such land shall first be obtained. All 
shade trees within the limits of any public way shall be deemed public shade trees.

Sec. 3. Whoever, other than a tree warden or his deputy, desires the cutting or removal, in whole or in part, of any public shade tree, may apply to the tree warden, who shall give a public hearing upon the application at some suitable time and place, after duly posting notices of the hearing in two or more public places in the town and also upon the said tree; provided, however, that the warden may, if he deems it expedient, grant permission for such cutting or removal, without calling a hearing if the tree in question is on a public way outside of the residential part of the town, the limits of such residential part to be determined by the selectmen. No tree within such residential part shall be cut by the tree warden, except to trim it, or removed by him without a hearing as aforesaid; but in all cases the decision of the tree warden shall be final.

Sec. 4. Towns may annually raise and appropriate such sum of money as they deem necessary, to be expended under the direction of the tree warden in exterminating insect pests within the limits of their public ways and places, and in the removal from said public ways and places of all trees and other plants upon which such pests naturally breed; provided, however, that when an owner or lessee of real estate shall, to the satisfaction of the tree warden, annually exterminate all insect pests upon the trees and other plants, within the limits of any public way or place abutting on said real estate, such trees and plants shall be exempt from the provisions of this section.

Sec. 5. Whoever affixes to any tree in a public way or place a play bill, picture, announcement, notice, advertisement or other thing, whether in writing or otherwise, or cuts, paints or marks such tree, except for the purpose of protecting it and under a written permit from the tree warden, shall be punished by a fine not exceeding fifty dollars for each offense.

Sec. 6. Whoever wantonly injures, defaces, breaks or destroys an ornamental or shade tree within the limits of any public way or place shall forfeit not less than five nor more than one hundred dollars, to be recovered by complaint, one-half to the complainant and the other half to the use of the town.

Sec. 7. Whoever negligently or carelessly suffers a horse or beast driven by or for him, or a beast belonging to him and lawfully in a public way or place, to break down, injure or destroy a shade or ornamental tree within the limits of said public way or place, or whoever negligently or willfully by any other means breaks down, injures or destroys any such tree, shall be liable to the penalties prescribed in the foregoing section, and shall in addition be liable for all damages caused thereby. 


\section{NEW HampshiRE.}

Chap. 98, Laws 1902. Sec. 1. Mayors of cities and selectmen of towns shall appoint one or more tree wardens to be paid as the mayor or selectmen direct.

Sec. 2. Towns and cities shall control all the shade and ornamental trees in the public ways which the warden deems reasonably necessary. The warden shall mark all such trees.

Sec. 3. If any such trees prove to be private property the warden shall acquire them if it is possible to do so at a fair price. If unable to agree on price they may be acquired as provided for acquiring land for highway.

Sec. 4. Appropriations may be made not exceeding fifty cents for each ratable poll to be used for planting and caring for such trees.

Sec. 5. Provides for cutting trees upon consent of warden.

Sec. 6. Prohibits defacement except on consent of warden.

Sec. 7. Prohibits owners of land from burning brush near trees.

Sec. 8. Provides penalties for violations.

\section{CONNECTICUT.}

Chap. 244, Laws I902. Bounty.- Every person planting, protecting and cultivating elm, maple, tulip, ash, basswood, oak, black walnut, hickory, apple, pear, or cherry trees not more than sixty feet apart along any highway, to be paid ten cents for each tree, but not for more than five years.

Tree Wardens.- Each town may select a tree warden who may appoint deputies who are to be paid as the town may prescribe. He is to have control of all public shade trees in town except in parks under Commissioners. He may make rules for the care and preservation of such trees, to be enforced by fines not to exceed twenty dollars in each case. Such rules when approved by the town officials and posted liave the force of town by-laws.

Planting Shade Trees.- Towns may appropriate sums not exceeding fifty cents for each ratable poll, to be expended by the tree warden in planting trees in the public ways, no trees to be planted without the consent of the adjoining owner. All transplanted trees and all other trees over six inches in circumference to be deemed public shade trees.

Removal of Shade Trees.- Provision is made for the removal of shade trees, with the consent of the tree warden, and for the destruction of insect pests. Persons injuring shade trees by cutting, painting, advertising on, etc., without the consent of the tree warden, shall be fined not exceeding fifty dollars. Every person willfully injuring a shade tree in a public place shall be fined not to exceed one hundred dollars. 


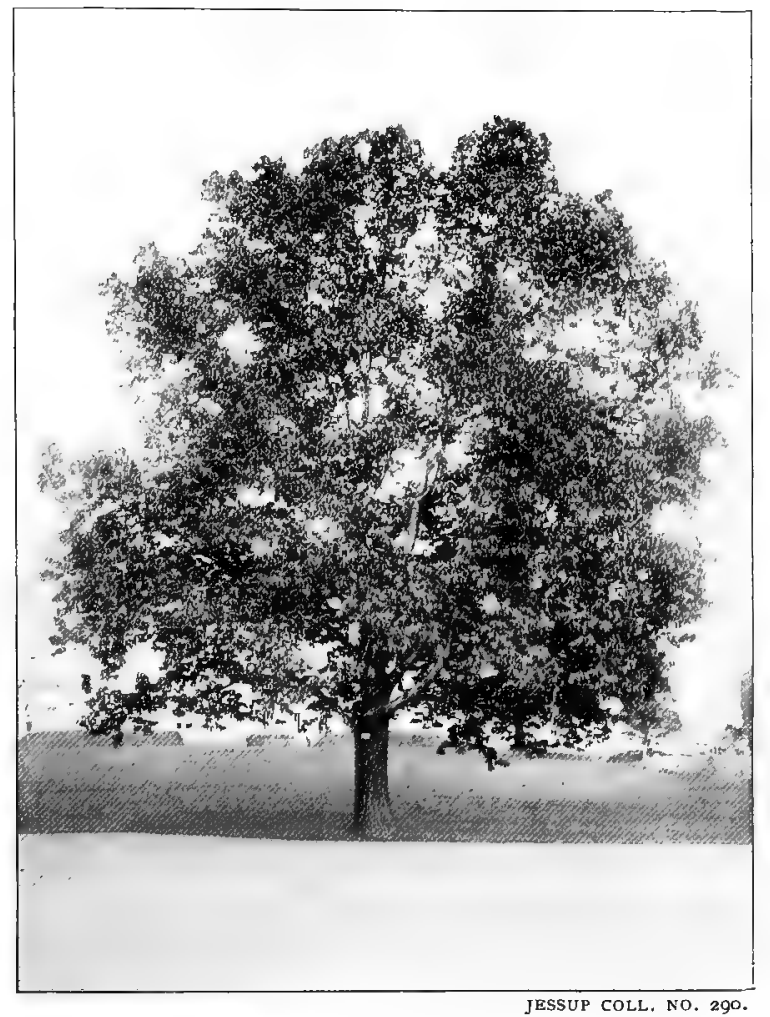

COMMON AMERICAN CHESTNUT.

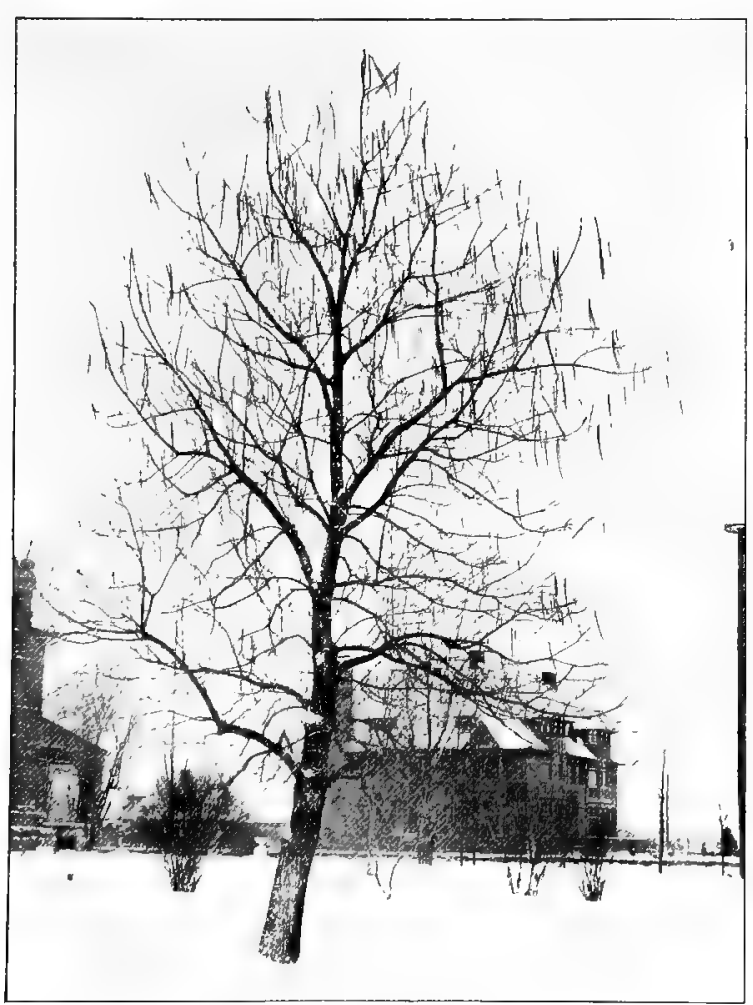

HARDY CATALPA.

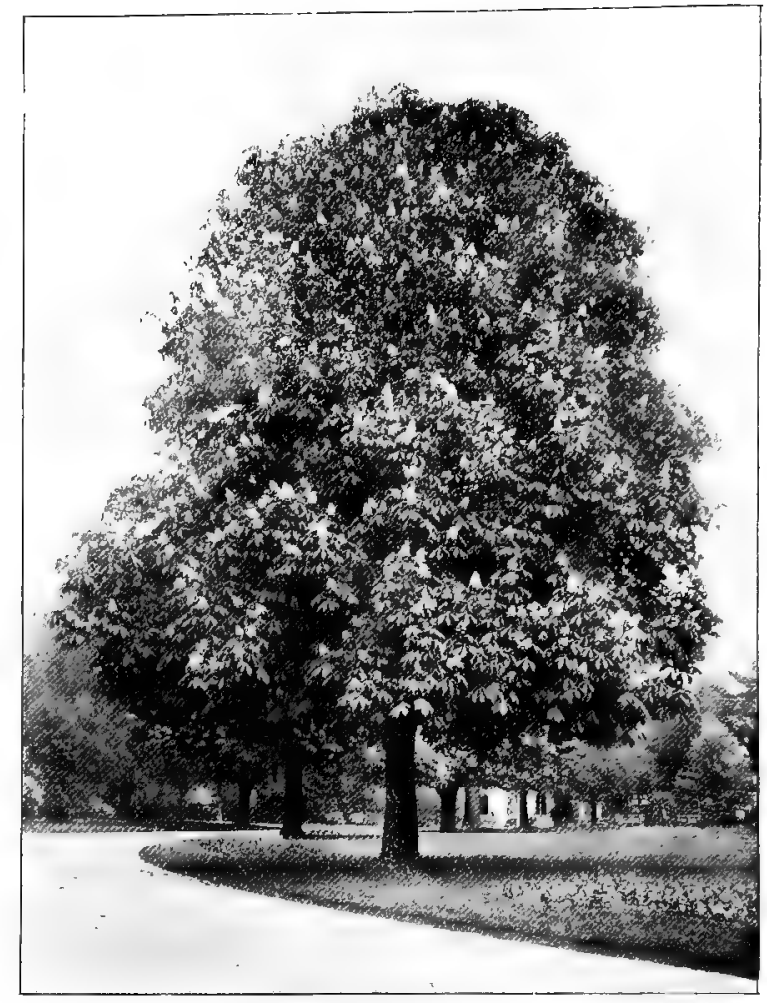

HORSE CHESTNUT.

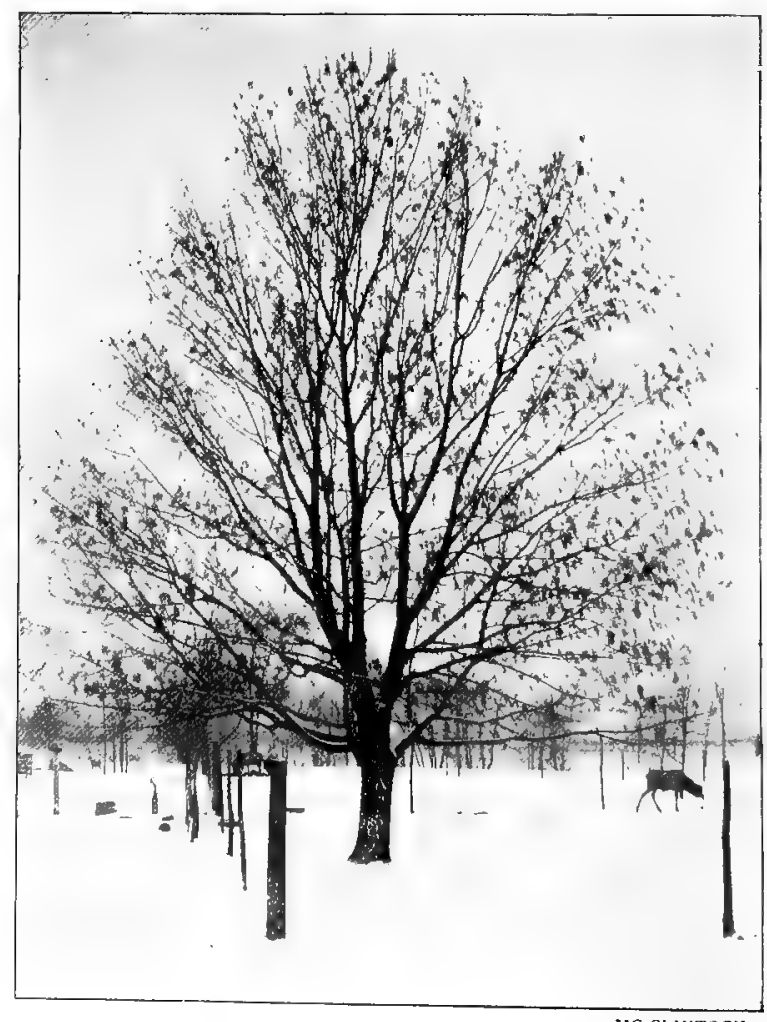

WHITE ASH. 


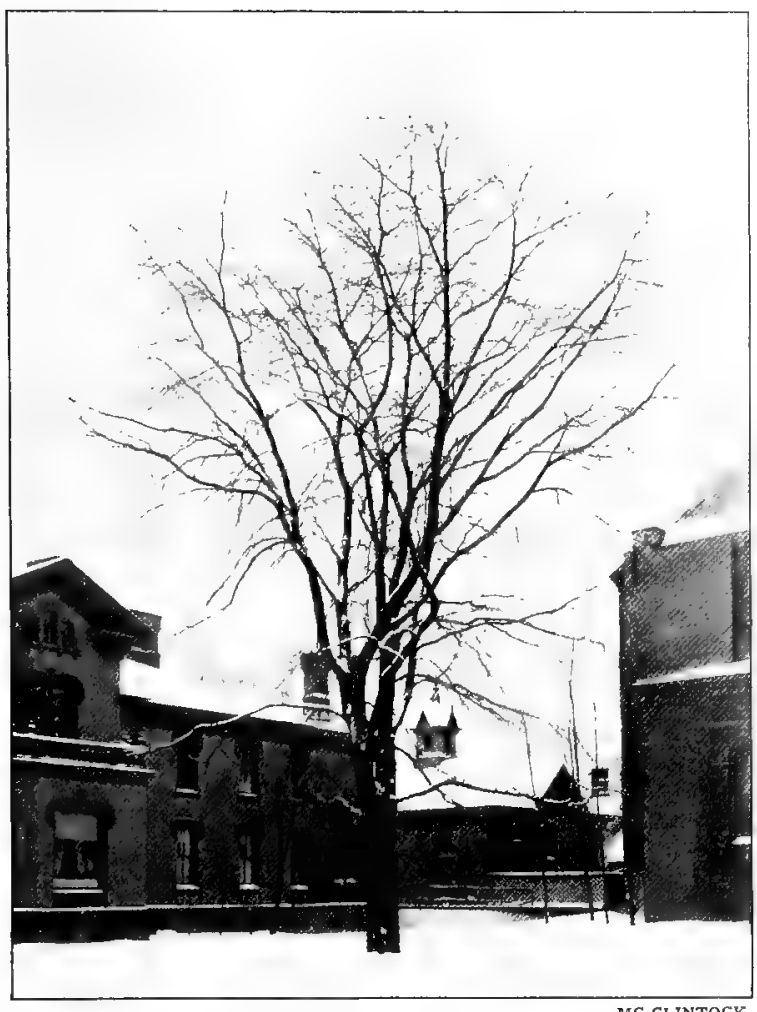

HONEY LOCUST.

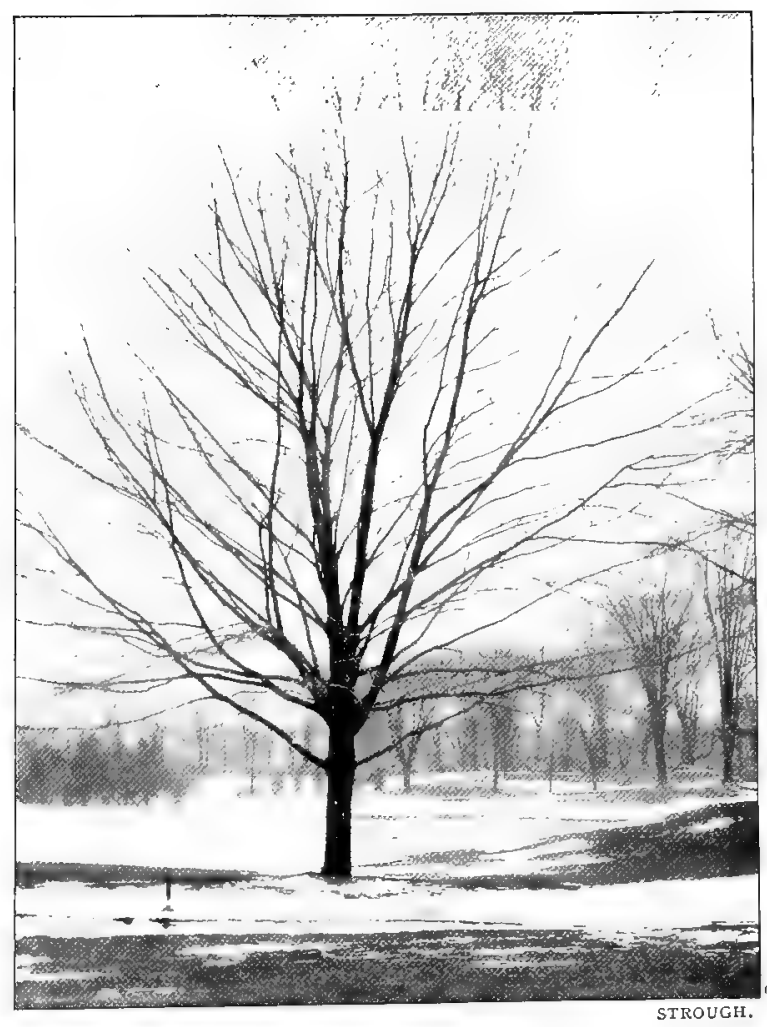

NORWAY MAPLE.

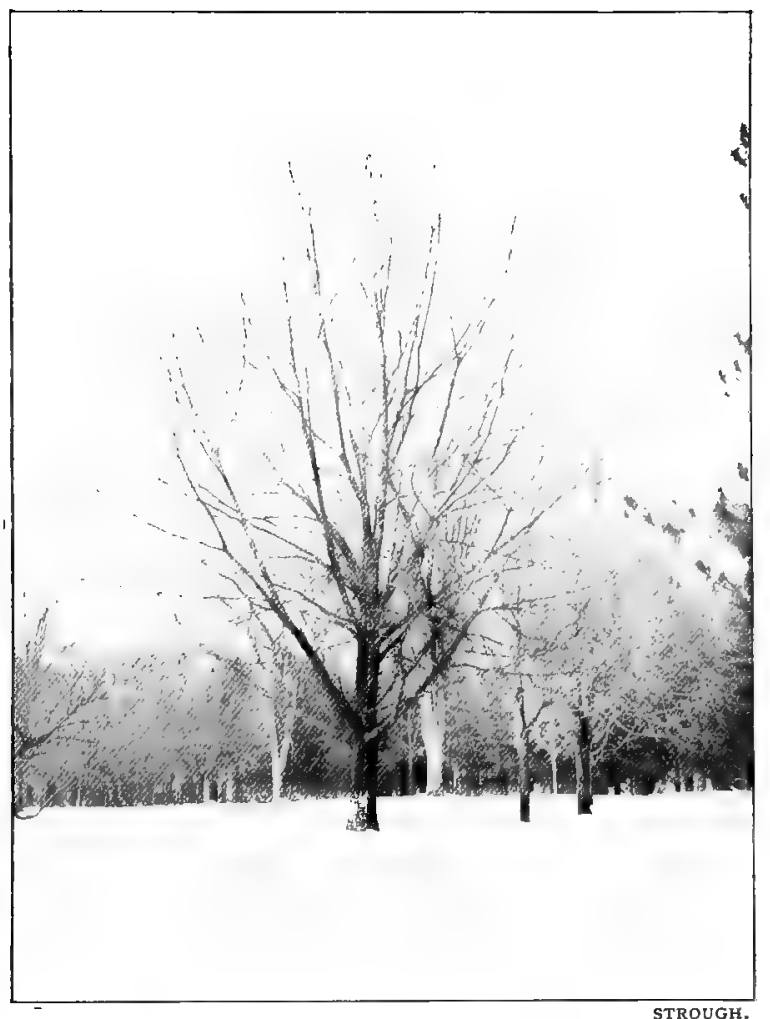

RED OAK.

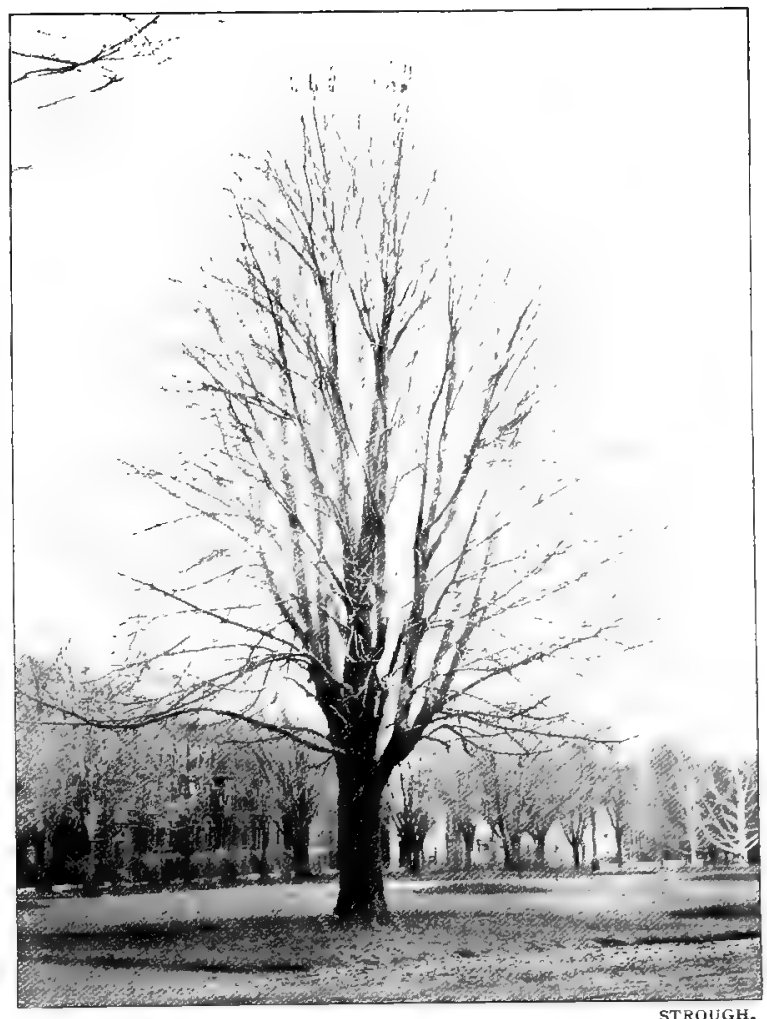

WHITE MAPLE. 



\section{PenNSYlVANia.}

Chap. 275, Laws Igor. Sec. I. The burgess and council of any borough upon petition of a majority of the property owners on any public street may by ordinance require the planting of shade trees, and on failure of the owners, after notice, to plant, may cause the planting to be done and collect the same from the adjoining property owners.

Chap. 306, Laws I90I. Sec. I. Any person liable to road tax who shall transplant to side of road on his own premises any fruit, shade or forest trees of suitable. size shall be allowed on road tax one dollar for every two trees set out. No row of elms to be placed nearer apart than seventy feet; and no row of maples or other forest trees nearer than fifty feet, except locust and Carolina poplar, which may be thirty feet, and except fruit trees may be set forty feet; and all must be living and protected from animals.

Sec. 2. Any tree growing naturally by side of highways through cultivated land . shall be allowed in same manner.

Sec. 3. Trees planted on highway in place of trees that have died shall be allowed for as provided in first section.

Sec. 4. No person to be allowed more than quarter of his annual road tax.

Sec. 5. Any person who cuts or injures any live tree planted or growing naturally as aforesaid, or suffers an animal of his to injure such a tree, shall pay a penalty of from one dollar to five dollars, or he may plant and maintain another tree in place of the one cut or injured.

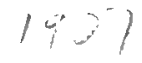

NEW JERSEY.

Chap. 285, Laws 1893. Sec. I. Provides that there may be appointed in all municipalities a Commission of three freeholders without compensation, who shall have control and power to plant and care for shade trees on any of the public highways.

Sec. 3. Notice must be given when planting is contemplated, specifying streets, etc, and must be published in papers.

Sec. 4. The cost of planting, including guards around the trees, to be borne by the adjoining real estate. The same is a lien thereon and may be collected with the taxes.

Sec. 5. Cost of maintenance after planting is to be borne by municipality.

Chap. I62, Laws I896. Sec. I. Makes it unlawful to hitch or tie animals to trees adjoining any highway. Animals must not be left unattended near any such tree.

Sec. 2. Provides for penalties. 


\section{OHIO.}

Statutes. Sec. 2307. Provides that upon petition of more than two-thirds of the ownership in feet on streets of cities of the second class and villages the council may provide by ordinance for planting and taking care of shade trees.

Sec. 2308. Provides that the ordinance may designate two of the petitioners to act without pay, who with the corporation engineer shall constitute a Board who may plant and care for the shade trees. Term of office, three years.

\section{MinNesota.}

Chap. 243, Laws I895. Sec. 2. The Park Commissioners of each city are empowered to regulate the planting and preservation of shade trees in the streets and public grounds. No shade tree shall be destroyed except by leave of the Commissioners. The Commissioners may by ordinances provide for the enforcement of this section, and fix penalties for a violation of the same.

Sec. 3. Upon petition of a majority in number of the owners of real estate abutting any street asking for the planting of trees, the Commissioners may plant suitable shade trees along any part of such street.

Sec. 4. Provides for assessing the cost of such tree planting and maintenance for three years, on the owners of property benefited.

Sec. 5. Provides that the assessment must not exceed fifty cents per foot on any land benefited, and that trees that die must be replaced without further assessment.

Chap. I7I, Laws I899. Provides for tree planting in cities of more than 50,000 people.

\section{CALIFORNIA.}

Chap. 140, Laws 1893. Sec. I. All public streets may be planted with shade trees along the sidewalks by order of the City Councils.

Sec. 2. Provides method of procedure in passing resolution for planting trees.

Sec. 3. Provides for hearings by owners of land adjoining streets to be planted, and that the choice of trees to be planted shall be governed by request of majority of owners of frontage.

Sec. 5. Provides for furnishing trees, and for planting under a contract which shall provide for care and maintenance for three years.

Sec. 7. Provides that all the work must be done under the direction of the superintendent of streets.

Sec. 9. Requires that the cost of street tree planting shall be assessed on the adjoining land. 
Sec. I2. Provides for replacing dead trees after three years.

Sec. 13. Provides that the act shall apply to such municipalities as shall vote to come within its provisions.

\section{FLORIDA.}

Chap. 74, Laws 190I. Sec. I. The County Commissioners are empowered to improve by shading the public roads and highways of their respective counties.

Sec. 2. It is the duty of said Commissioners upon petition of a majority of the freeholders along any public road to improve the same by planting suitable shade trees on such part as is mentioned in the petition, the work to be done in regular order and at proper season.

Sec. 3. Provides that upon petition of land owners the Commissioners shall set shade trees not less than three nor more than six inches in diameter, and not less than ten feet high, at a distance of one eighth mile apart and fifteen feet back from the center of the road on each side in two parallel lines as markers to guide the setting of remaining trees.

Sec. 4. Provides that after markers and guides are set as per Sec. 3, the Commissioners shall purchase suitable trees and cause them to be set by contract, not less than ninety feet nor more than one hundred and ten feet apart, to be placed so as to alternate with trees on opposite side of road. Trees are not to be paid for until they have put on sufficient growth to insure continued life; not more than twentyfive cents shall be paid per tree. The trees must be purchased from free holders and taxpayers, and not more than ten dollars shall be paid to any one in one year.

Sec. 5. Provides for paying the expense of planting out of the road tax fund.

Chap. I2I, Laws Igor. Sec. I. Provides that it shall be unlawful for any person to cut any shade tree within fifteen feet from center of road bed without permission from proper authority.

Sec. 3. Provides that an offender shall be fined not less than five dollars nor more than twenty-five dollars.

It is evident from the foregoing extracts that the absence of shade trees on our streets and highways is not due to any lack of legislative provision for their installation, care, and maintenance. All that is needed now is a stimulation of public interest in this subject. This can be best accomplished by the organization everywhere of tree planting societies, village improvement leagues, outdoor art associations or any movement which, through combined, intelligent effort, will have an opportunity to assert itself and attain the desired beneficent results.

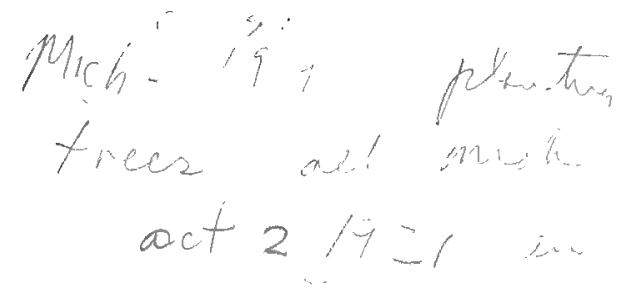




\section{Aotumn Foliage.}

In the selection of species for street and highway planting some consideration should be given to the colors which the leaves will display in the fall months, a matter as important as that of tree habit or graceful outline. Although a purely esthetic one its importance has been urged at times by scientists as well as writers on woodland scenery. We hail with pleasure the green foliage of each returning spring, but delight none the less in the brilliant display made by the painted leaves in autumn, and, so, when we come to choose our trees for planting, everything else being equal, why not give a preference to the species which afford a pleasing aspect in both spring and fall.

In considering this question it is well to remember that, while certain species generally show the same color each fall, there is apt to be some variation in this respect. Occasionally some individual will exhibit an entirely different tint from the prevailing one of that species, while frequently several tints, and at times two or more distinct colors, will be found on the same tree. The Red Maple is noted for the scarlet hue of its leaves in early fall; but here and there a tree of this species will display a yellow foliage at that season. Then, again, the other Soft Maple, the White or Silver Maple, which generally turns yellow, will in some places present a single tree with leaves showing a red color to considerable extent.

Most of our Oaks are a brilliant red or scarlet in October, but some of them change each autumn from green to russet without the usual intermediate bright tints that generally precede the russet. The Hard, or Sugar Maple, cannot be classified under any one particular color, for it not only displays various ones on the same tree, but green, yellow, and red are often found on the same leaf. The leaves on some species, the White Ash for instance, show three or four successive tints during their transition, passing from yellow to a beautiful shade of brown. On some trees, noticeably the Red Maple, a single branch will assume a brilliant color, generally red in August, while the rest of the foliage is still green. This may be attributed to some lack of vitality in the particular branch thus affected.

It has been observed that when a tree shows a distinctive sport of this kind the peculiarity is a persistent one, and its recurrence may be looked for each year. If a Red Maple displays one highly colored branch in early August, while all the rest of its foliage is green, it may be depended upon to exhibit the same phenomenon next season. The White Maple, as a rule, has yellow leaves in autumn; but if some one tree of this species shows a mixture of red and yellow in its leaves it will surely do the same through each successive year On some Oaks the leaves, instead of turn- 

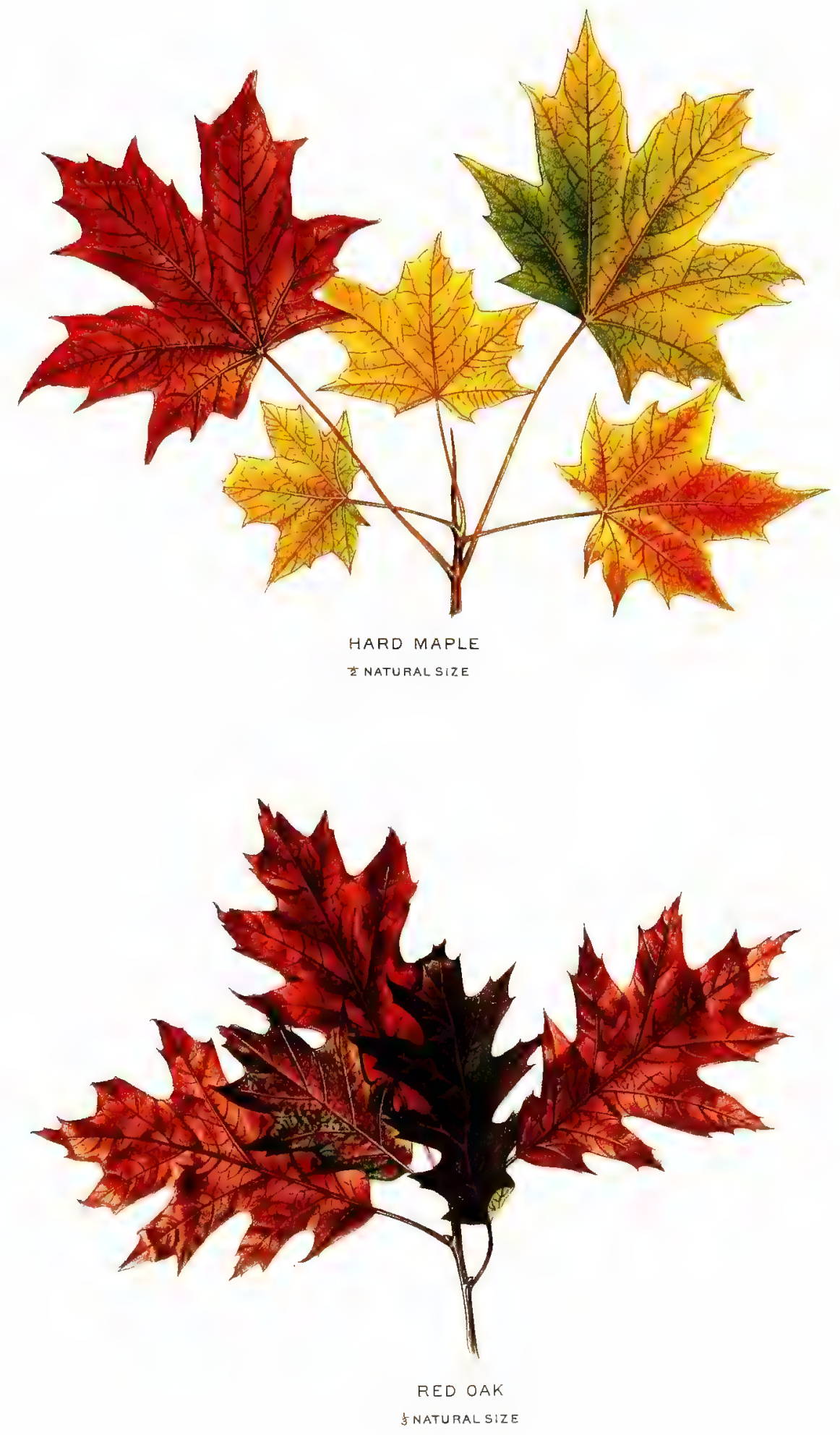



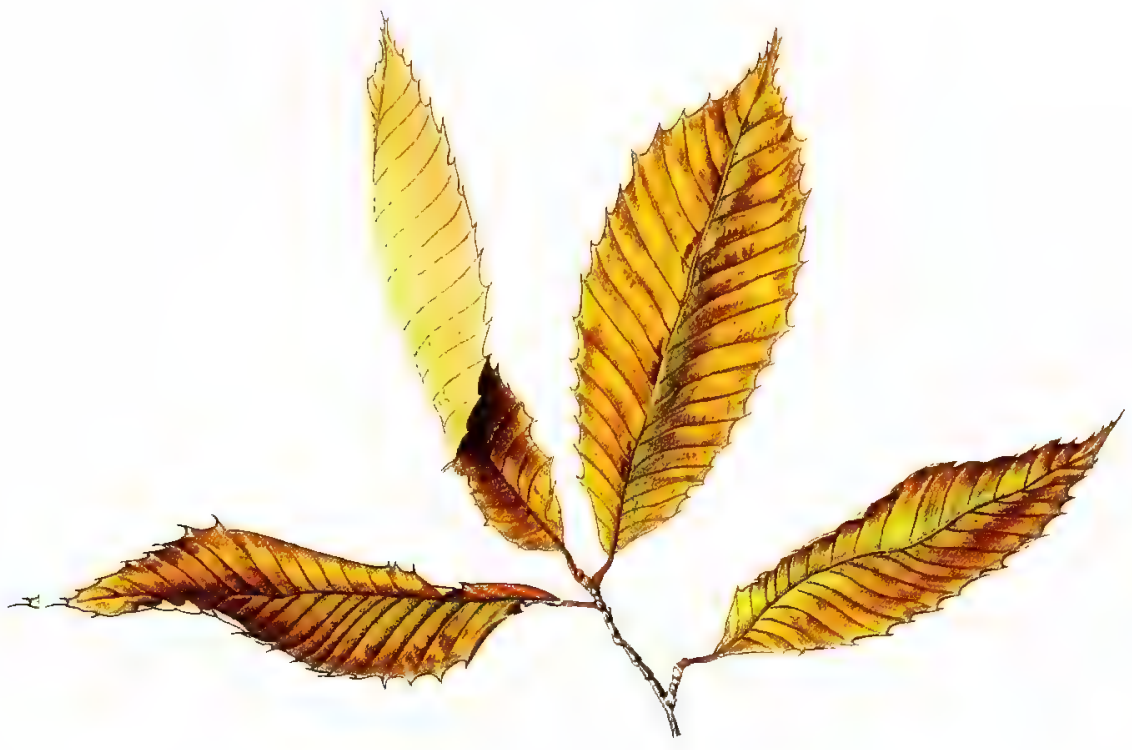

CHESTNUT

$\frac{1}{2}$ MATURALSIZE

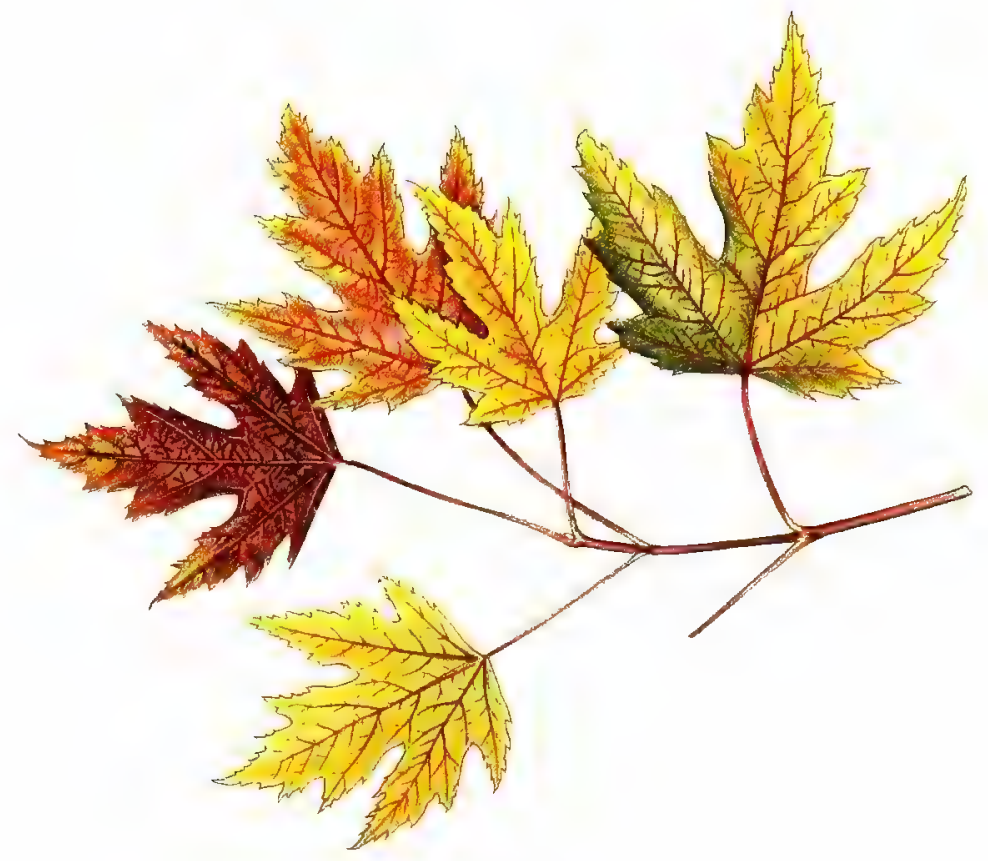

WHITE MAP_E

ENATURA_S.ZE 



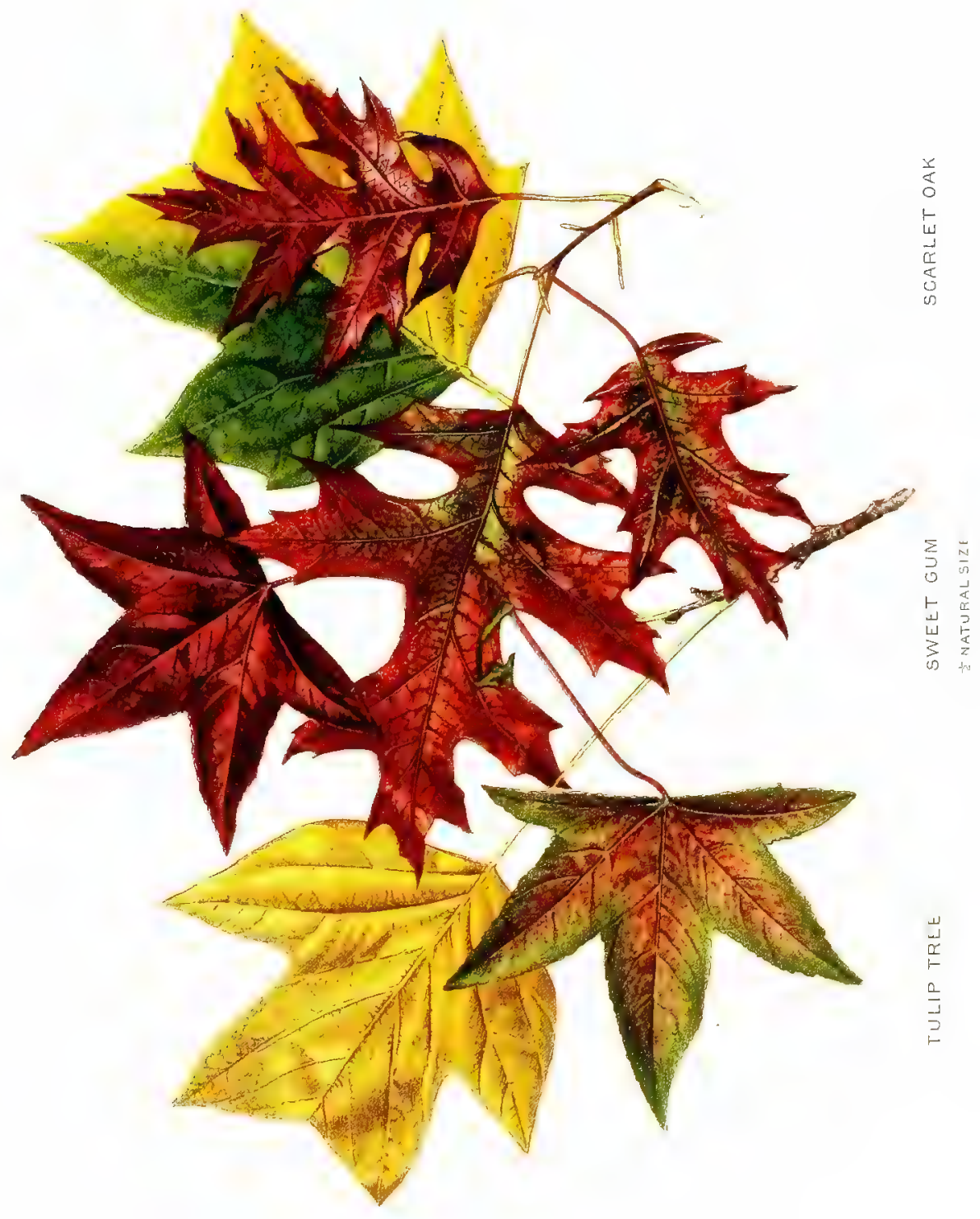




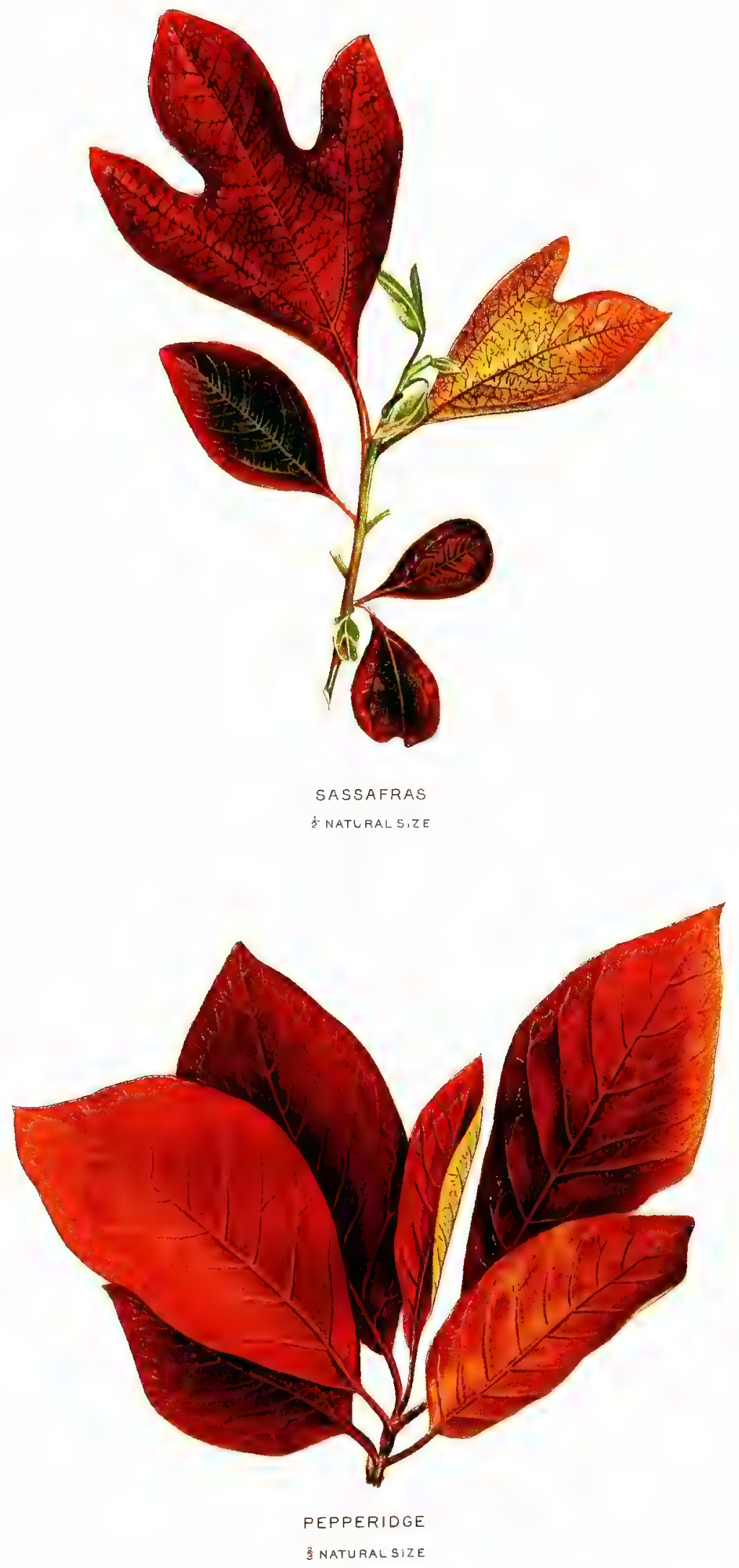



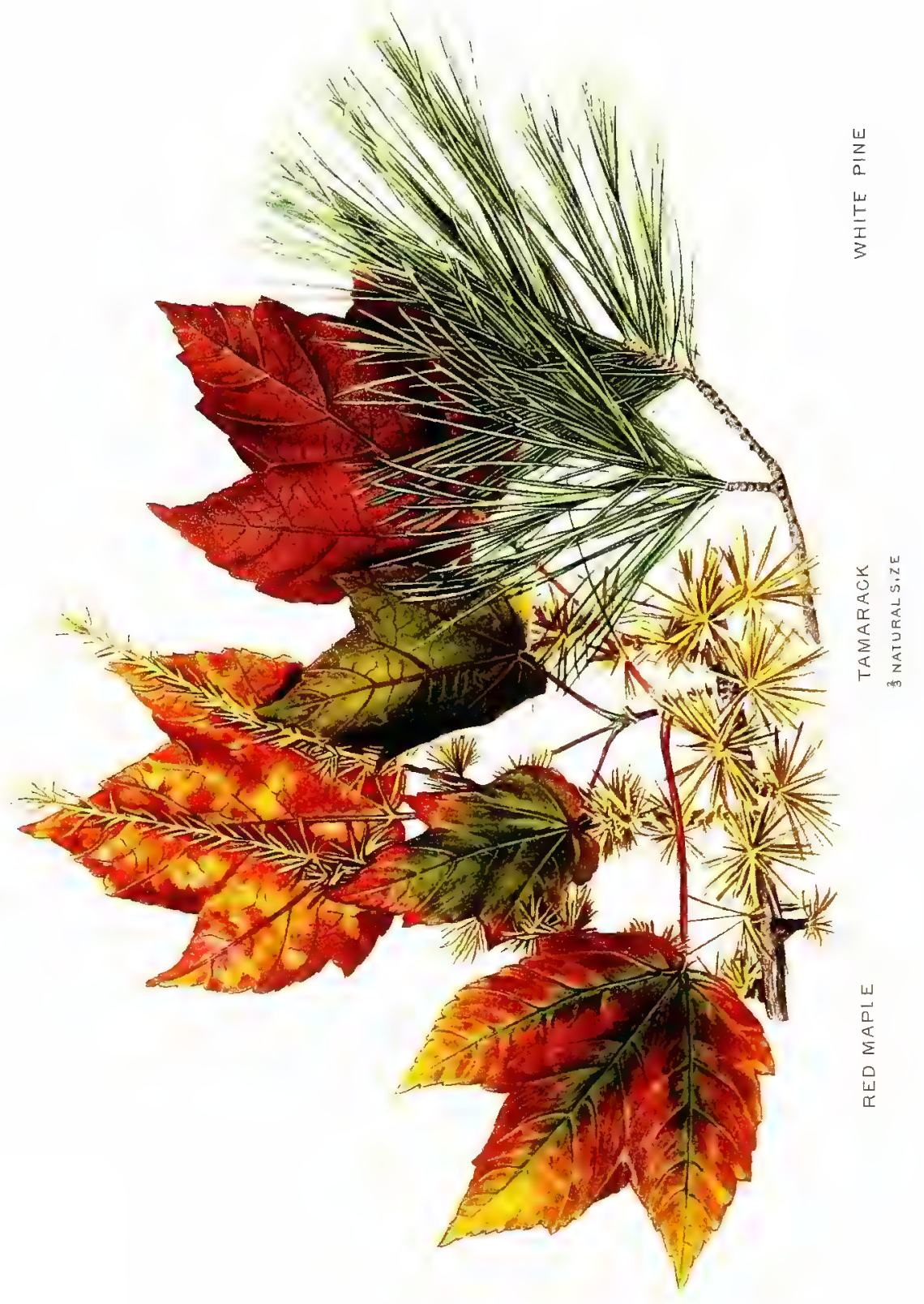





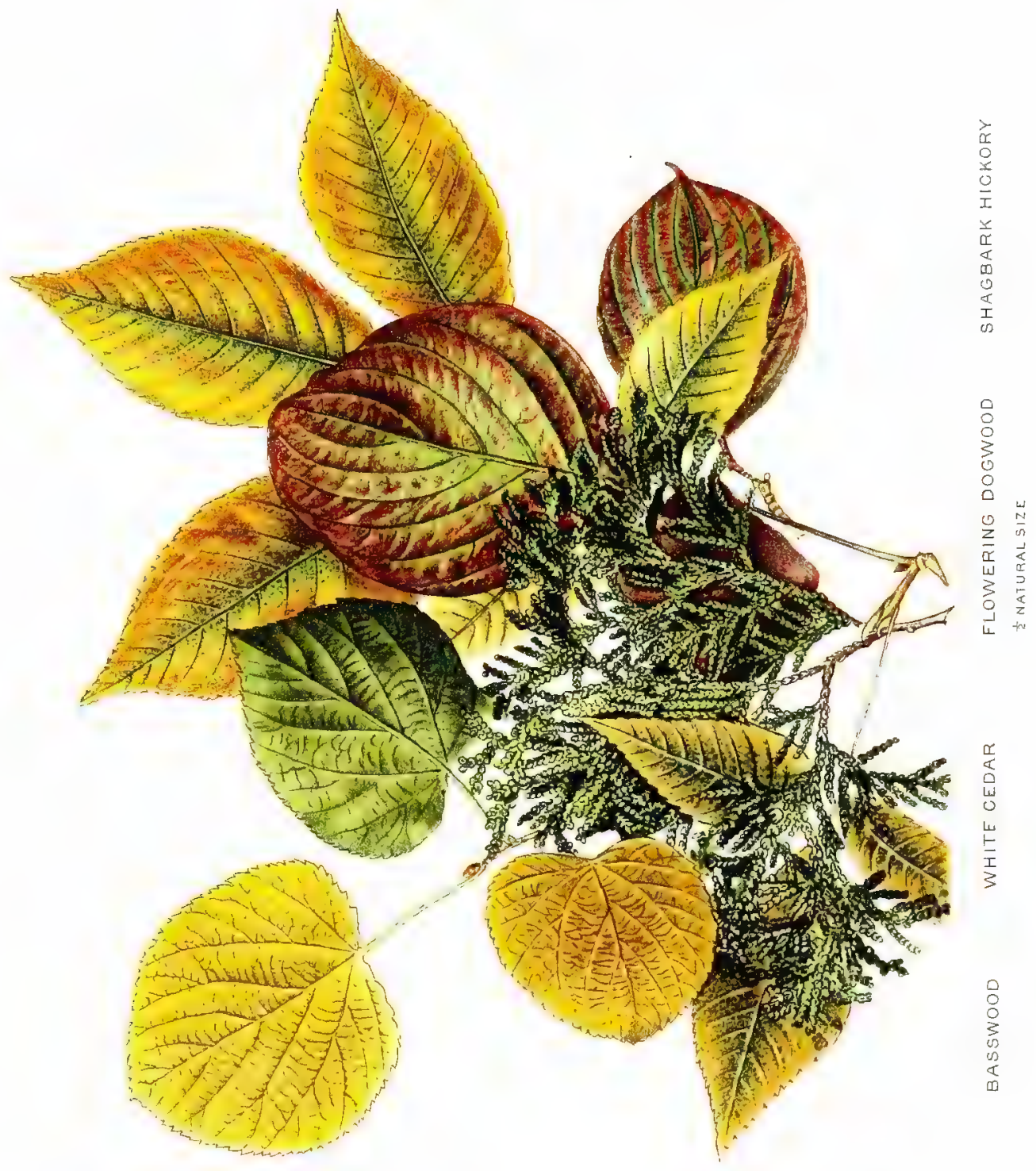





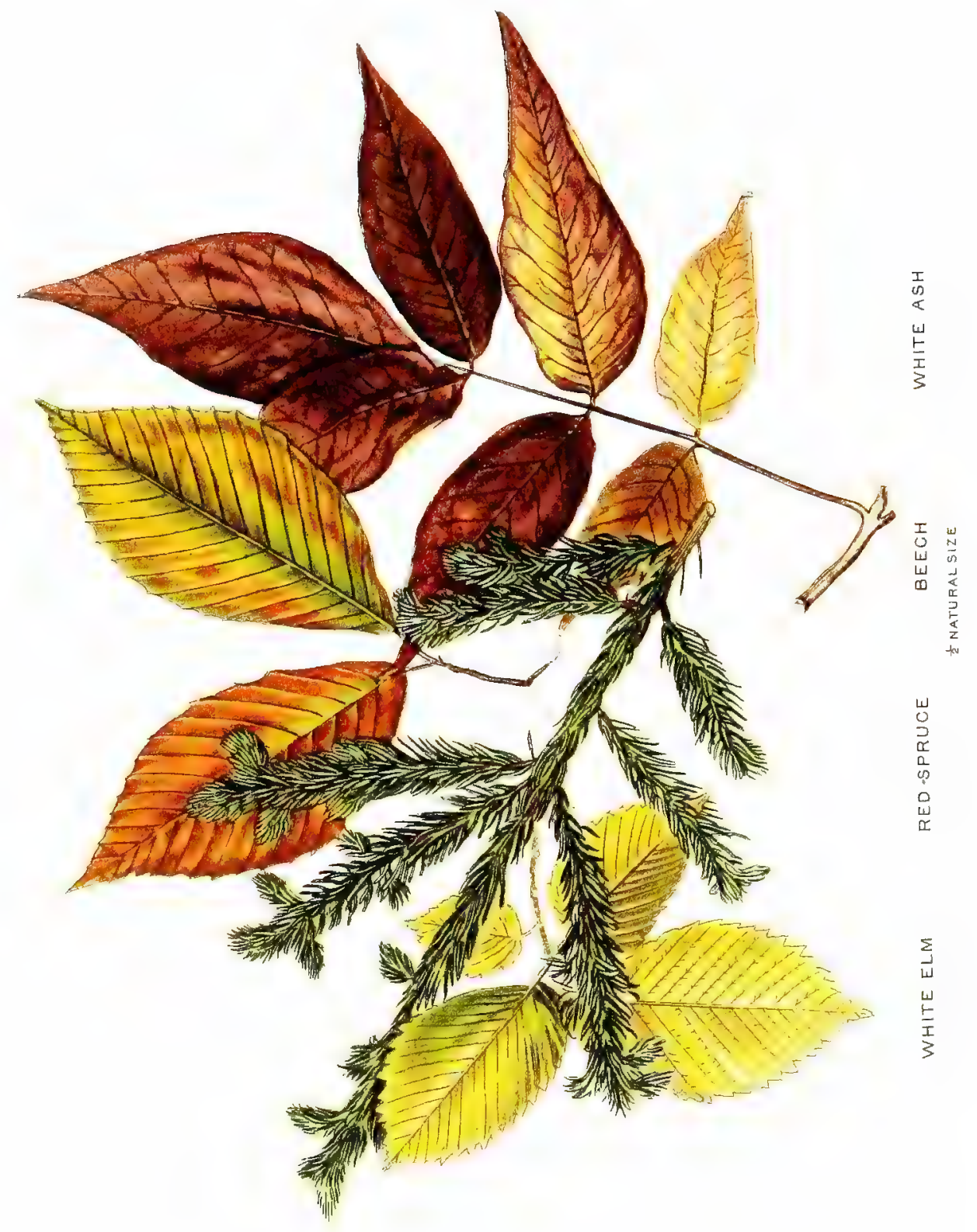





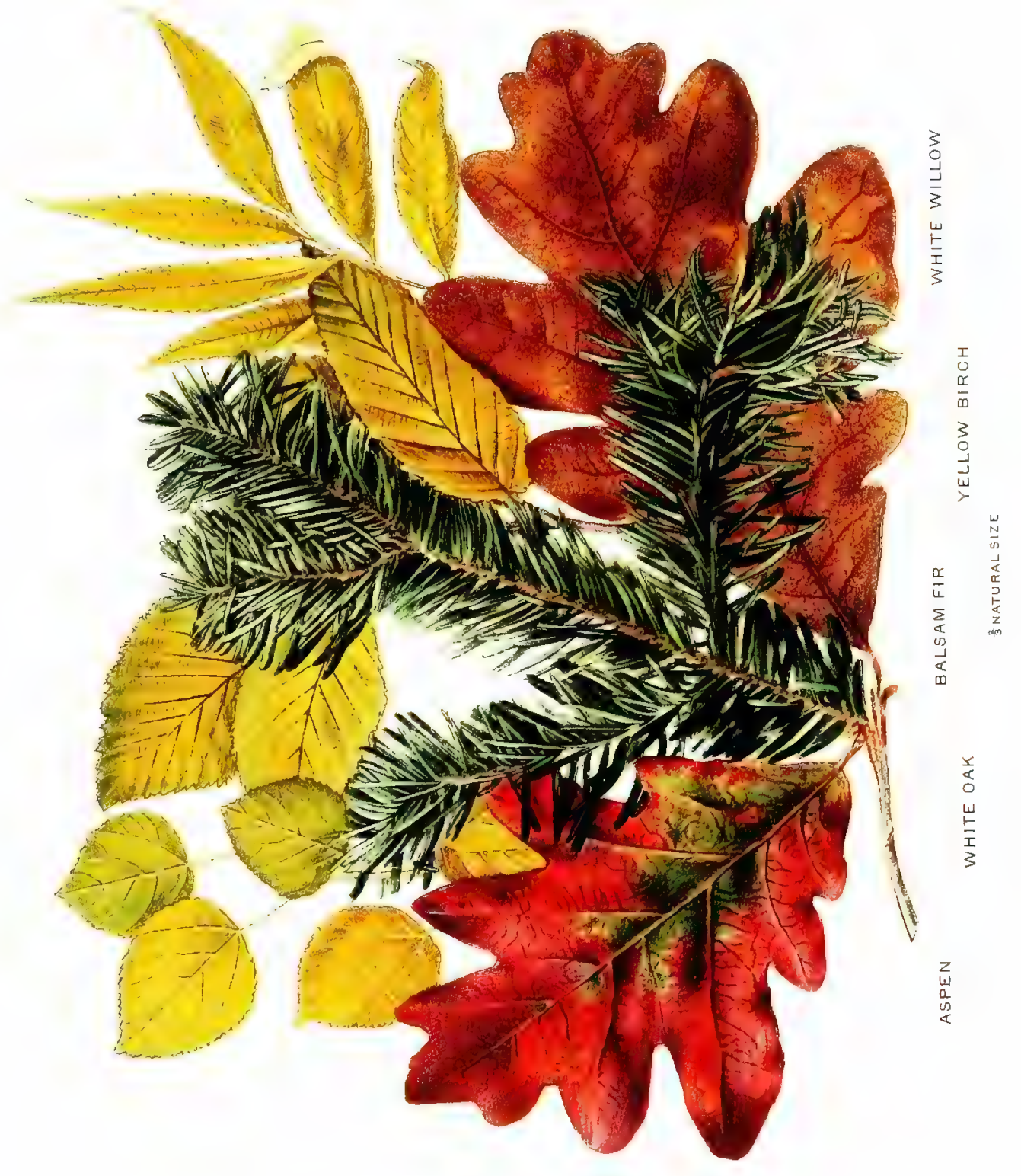



ing red, change from green to yellow or russet; but, whatever the peculiarity in this respect, each individual will retain it in a marked degree year after year. The persistency of this abnormal variation in color has been observed so often that the reasonable suggestion is made that horticulturists and nurserymen might be able, by using cuttings or grafts from trees or branches that exhibit a constant color, to propagate trees of desirable autumn tints and furnish stock to their customers, warranted to display certain attractive features in this respect. The Purple or Copper Beech, used so extensively in lawn planting, was propagated in this way from a single tree, which showed an abnormal color in its foliage.*

There seems to be a popular impression that the period in which our forests display their autumnal beauty is of brief duration. A little thought and observation will show that this is hardly the case. By the first of August, throughout New England and the Middle States, many of our soft maples display their scarlet standards of approaching fall; in September the forests on our mountain slopes . and upland plateaus are at their best; in October the woodlands along our valleys, and the trees that line our village streets, present their most brilliant effects; and even in November the persistent russet leaves of the oaks are still in pleasing evidence, while here and there on some late maturing trees may be seen a faint glow befitting this twilight season of the year. Thus we have four months in which to study this pleasing exhibition of Nature, a period nearly as long as that in which the vernal foliage retains its uniformity of green. It would seem, however, that the annual recurrence of this lavish display is not appreciated as it should be, that little attention is paid to it aside from the few who delight in Nature study. Thoreau very justly remarks that "If such a phenomenon occurred but once it would be handed down by tradition to posterity, and get into the mythology at last."

Like the procession of the seasons the various tree species assume their autumn garb in a regular order. In some localities it may be early or late; but, then, our spring or fall does not always arrive in accordance with the almanac. Here and there individual trees may be slow in donning their gay livery; and there are spots where winter lingers, though all around the land is warm with returning spring.

To give the exact order in which the trees turn color would require too many exceptions and explanations. As the maturing of the foliage occupies a period of

* "Most of the purple beeches now in cultivation are probably derived from a tree of this variety, discovered in the last century in the Hanleiter Forest, near Sondershausen, in Thuringia, which is supposed to be about two hundred years old, and is still alive." (Prof. Charles S. Sargent. Silva of North America, Vol. IX, p. 24.) See, also, "The Origin of the Purple Beech." Garden and Forest, VII, 2. 
about three months the species may be divided into three groups showing their order in this respect, although no group can be assigned with accuracy to any one month. Their succession is approximately as follows:

\section{GROUP ONE - THE EARLIEST.}

Red Maples, White Elm, Sumach, Yellow Locust, Sour Gum, Horse Chestnut, White Maple, Yellow Birch, Hickories, Tulip Tree, Sassafras, Butternut, Black Walnut, Cucumber Tree, Kentucky Coffee Tree.

\section{Group Two - The Intermediate.}

Hard or Sugar Maple, Sweet Gum, Chestnut, Yellow Wood, Red Oak, Pin Oak, Beech, White Birch, Black Birch, Aspens, White Ash, Hop Hornbeam, Blue Beech, Carolina Poplar, Basswood, Black Ash.

\section{Group Three - The Latest.}

Scarlet Oak, Dogwood, Honey Locust, Lombardy Poplar, White Oak, Larch, Black Cherry, Sycamore, Sycamore Maple, Norway Maple, Ailanthus, Dutch Linden, Ginkgo, Willows, English Elm.

It would, undoubtedly, be interesting to state here the month and, approximately, the day of the month on which each species might be expected to display its ripened hues. This might not be so very difficult as regards any particular locality; for continued observations of individual trees show that they vary but a few days each year, both in the vernal unfolding and the autumnal ripening of the leaves. But, as the time of the process varies greatly with latitude and situation, no one schedule of dates would fulfill the purpose; and so each student must construct his almanac in accordance with the dates noted in his own vicinity. If a person who keeps a diary faithfully will note in spring the first day on which each species may be said to be in leaf, and in fall when these same trees have fairly changed color, such memoranda will prove valuable for future reference. For many years the writer has thus timed the late and early springs by a clock of the seasons constructed from just such notes.*

Although, as previously shown, some species may exhibit two or more colors, there are certain prevailing tints which may be looked for in connection with each.

* "The illustrious Linnaeus, in the most earnest manner, exhorted his countrymen to observe with all care and diligence at what time each tree expands its bucls and unfolds its leaves; imagining, and not without reason, that his country would, some time or other, reap some new and perhaps unexpected benefit from observations of this kind made in different places." [Harold Barck. Foliation of Trees. Amaen. Acad, Vol. III.] 
Observers may differ some as to the shades noted, and it must be conceded that no classification can be made that will be absolutely comprehensive and correct. The following schedule is submitted as tentative rather than final:

\section{Prevailing Colors.}

Pure Yellow. Tulip Tree, Yellow and Canoe Birches, White Maple, Yellow Locust, Honey Locust, Yellow Wood, Norway and Sycamore Maples, Beech, Willow, Cucumber, Ailanthus.

Yellow Ochre. Larch, Poplar, Aspen.

Lemon Yellow. Hickories, Black Walnut.

Dull Yellow. White Elm, Chestnut, White Birch, Basswood, Butternut, Catalpa, Cottonwood, Bur Oak.

Vandyke Brozen. Sycamore or Buttonwood.

Orange. Black Birch, Horse Chestnut, Ginkgo.

Red. Scarlet Oak, Sumach, Dogwood, Hornbeam.

Scarlet, Crimson and Yelloze. Red Maple.

Red, Yellow and Green. Hard Maple, Sassafras.

Scarlet, Crimson and Purple. Sour Gum.

Purplish Red. Red Oak.

Red and Russet. Black Oak, White Oak.

Red, Yellow and Brown. Sweet Gum.

Brown, Purple and Salmon. White Ash.

Raw Umber. Scrub Oak.

The collector of specimens will find it difficult to secure perfect leaves of a straight color, ones in which the entire surface has turned to a uniform shade. There is apt to be some small area of green, spots of uneven color, or defacement of the surface. A careful search will occasionally reveal an unbroken leaf of pure unstained yellow; but the reds almost invariably retain some of the original green, or are uneven in color.

In noting the colors assumed by various species the observer should make a close distinction between ripe and dead leaves. There is both a ripening and decaying process in leaves as well as fruit. The ripening stage proceeds until a separating tissue or film forms between the petiole and the twig, and then, the supply of nourishment having been cut off, the leaf dies and falls. The yellow ones soon fade or turn brown after they drop; the red ones retain their color longer, and when prop- 
erly pressed undergo little change in this respect. A ripe leaf while on the tree is still soft and flexible, whatever its color may be; a dead one is faded and sear, generally crisp and of a dull brown.

Bright colored specimens can be preserved by placing them immediately between sheets of blotting paper on which heavy weights, books, for instance, should be placed. Mr. Justus W. Folsom in an article on "Autumnal Changes in Leaves" (Garden and Forest, Vol. VIII, p. 383), says that they are best preserved by covering them with a sheet of paper, pressing with a hot iron upon which paraffine has been rubbed, and flattening and drying between papers afterward. Leaves thus prepared will retain flexibility and color for years; but if pressed without paraffine they will soon become dull and brittle.

The colors mentioned in connection with the different species are the ones which the trees may be expected to show in autumn. But on some there will be various exceptional tints, especially the Maples, among which may be found individuals bearing parti-colored leaves, some of them figured, striped or mottled like the wing of a gay butterfly. The White Ash leaf in ripening passes successively from a yellow to a dark bronze, violet, and chocolate brown, while here and there a leaf will display a lilac hue during this transition.

Still, the most of our trees show only some shade of yellow, and if we had to look to them alone the autumn would lose much of its brilliant beauty. Fortunately, the reds and scarlets which add so much to the glory of our woods and landscapes in September and October, are furnished in profusion by the larger shrubs that, in the openings along the country lanes and by the water courses, display their masses of flaming color. While yellow is the predominating autumn color of the trees, red prevails in the foliage of our shrubs and bushes.

A careful observer will note that much of the autumnal brilliancy seen in fields and on wooded slopes is due to humble species of our minor flora that are seldom mentioned in connection with this subject. Early in August the Hobble Bush displays its purple harbinger of fall, while along the roads and waste places the Sumachs show a profusion of leaves that look as if they had been "dipped in blood." By September the Poke Weed decks the rocky hillsides with the flaming mass of color afforded by fruit and foliage and stem. A score of minor species, shrubs and briers, together with the underlying mass of humbler weeds and purple grasses, add their varied hues, until the landscape exhibits all the warm colors of a Persian rug.

It is well to remember that some of our poisonous shrubs also assume b.ight, fascinating colors. The Poison Ivy, clinging to some tree, attracts the eye with the brilliant hues of its leaflets, crimson, scarlet or purple, while, more dangerous 
still, the pinnate leaves of the Poison Sumach entrap the fingers of the unwary with all the brightest colors seen in autumn. Hence the collector of bright specimen leaves should become familiar with the appearance and dangerous character of these shrubs.

There are some seasons in which the autumnal coloring of the foliage seems especially brilliant, although it is doubtful if there is as great a difference in this respect as might be inferred from the oft-heard remarks on this particular point. Opinions as to the comparative vividness of the tints in any year may vary according to the conditions under which chance observations are made. If a person journeys through a region in which, owing to the prevalence of certain species, only the yellow shades are seen, the absence of the red and scarlet tints may readily induce the opinion that the woods are not at their best this season; and, on the other hand, if the observations are made in places where the Oaks, Maples, and Gums light up the woods with their blazing colors, the natural conclusion is that the trees look unusually fine that fall.

The sportsman whose fall hunting is done in the vast brule of the Ottawa valley will see little aside from yellow on the trees, with no reds except on an occasional Maple or clump of Sumachs; while the tourist, looking from his car window at the Berkshire slopes or Short Hills of New Jersey would note with pleasure the scarlet foliage which the Oaks and various other species display annually throughout those places. Careful observations made each year of the mountain slopes in the Adirondacks and Alleghanies show no marked difference in the annual tinting of the forests. There may be some fall in which the maturing leaves seem to show a brighter color; but if the observation is made at the same place and on the same recurring date it would require a critical eye and good memory to distinguish the alleged variation.

It must be remembered, also, that these color effects are far more brilliant and impressive when observed on a bright, sunny day and in a dry, clear atmosphere; and that the autumn foliage loses much of its attractive appearance when viewed under cloudy skies or with the air obscured by haze or dampness. One beautiful effect of the sunlight in enhancing leaf colors may be obtained by standing under a White Oak, or any tree with red leaves, and looking towards the sun. With the transmitted light the leaves assume a far brighter color and a different hue than in reflected light; the dull, solid red changes into a fiery glow or rich wine color of marvellous beauty. In the Bronx park, near the path on the west side of the Beaver pond, stands a large White Oak which, on any bright afternoon in late October, will afford the visitor a good opportunity to study this charming revelation of 
nature. Still, there is a widespread belief that the autumn foliage is much brighter some years than in others, and it is conceded that this may be true to some extent.

In European countries the autumn foliage is generally inferior in brilliancy and pleasing effects to that in America. There is a lack of red, and even the yellow which predominates so largely there is dull as compared with that seen in our American forests. The Maples and Oaks are not so common, or of so great a variety. Furthermore, the American species planted there lose the brightness which they display at home, and, on the other hand, European trees grown in America fail to develop the brilliant colors of our native trees.

The inferiority of color so noticeable abroad has been attributed to a more moist condition of the atmosphere. This might apply with good reason to the British Isles and Netherlands, but hardly to sunny France, or to the South of Europe, famed for its clear Italian skies. A better reason may be found in the "greater transparency of our atmosphere, and the consequent greater intensity of light."

In his work on Autumnal Leaves,* Mr. Francis George Heath, of London, exhibits a series of twelve colored plates, in which he shows the tints of leaves collected by him in autumn from various leading species in England. The drawings are finely executed in both form and color; but, if the leaf tints have been correctly reproduced, their inferiority to the autumnal foliage in America is apparent at a glance. A comparison of the colored plates in Mr. Heath's book, with the pictures of autumn leaves shown in connection with this article, indicates plainly that, as to England at least, the leaves on American trees have colors far more brilliant, and in a greater variety.

The English botanist Hunter, in his notes on Evelyn's Silva, describes the September foliage in his vicinity as: "Plane Tree, tawny; Oak, yellowish green; Hazel, yellow; Sycamore, dirty brown; Maple, pale yellow; Ash, fine lemon; Elm, orange; Hawthorn, tawny yellow; Cherry, red ; Hornbeam, bright yellow."

Having mentioned the inferior appearance of the autumn foliage in Europe, as compared with that in certain American latitudes, it should be further noted that this difference applies to trees, and that it is not wholly true of the minor flora. In the Alps of Central Europe the shrubs and herbaceous growths above the timber line display ripened colors that, in variety and brilliancy, are unsurpassed in any country.

The direct influence of sunlight on the development of leaf color is apparent to the most casual observer. The outer leaves on a tree are the first to turn, while a

\footnotetext{
* Autumnal Leaves: By Francis George Heath. London: Sampson, Low \& Co. I88I.
} 
leaf that is thickly shaded by others is apt to remain green until it withers and dies. Where a twig or branch presses constantly on the surface of a leaf the part thus covered remains green after the rest has turned yellow or red. If you cut your initials from tin foil or thick paper and paste them on a large leaf the letters will in time be sharply defined in green on a background of yellow or red.

Why leaves should change color is as hard to explain or understand as why the hair turns gray. The scientists who have written on the subject admit that there is much to learn about the process and its cause. The leaf cells contain rounded granules of green matter known as chlorophyll, a substance-or mixture of substances - to which the pure green color of ordinary healthy leaves is due. The appearance of any other color, such as red, yellow or purple, would indicate the presence of some substance accompanying the chlorophyll and disguising its color, or even replacing it entirely.*

The leaf cells contain, also, xanthophyll, a peculiar yellow coloring matter, which remains after the decomposition or absorption of chlorophyll: and erythrophyll, which supplies the red or crimson shades found in matured leaves.

Most of the scientific explanations of the change of color are so technical that they are of little use to the general reader. The following extract from an article in the Botanical Gazette for April, I887, entitled, "The Autumnal Changes in Maple Leaves," by W. K. Martin and S. B. Thomas, is instructive and interesting:

"Chlorophyll, manufactured constantly under the influence of light, is constantly undergoing decomposition by the metabolism of the cell. Under ordinary conditions, the manufacture of chlorophyll is sufficient to cover up its decomposition, and the leaf retains its green color. Under certain changed conditions, however, such as intense light or diminished vitality, the decomposition of chlorophyll exceeds its manufacture, and xanthophyll (probably one of the products of decomposition) appears. In other words, xanthophyll is being formed all the time, but only becomes apparent when the manufacture of chlorophyll is checked. The condition of intense sunlight gives us the occasional summer yellowness, while to lowered vitality must be attributed the failure of chlorophyll manufacture in the autumn. This lower vitality is brought about by diminution of light, lowering of temperature, and probably causes in the plant itself. Xanthophyll then stains the chlorophyll masses yellow, which were before stained green by chlorophyll. The red coloration is brought about in a very different way, as erythrophyll is manufactured in the leaf, and stains the cell sap, leaving the chlorophyll masses untouched. This red coloring matter cannot be discovered in any of the crude materials brought into the plant, or in any other part of the leaves, except sometimes in the phlœum regions

\footnotetext{
* Webb's Dictionary of Chemistry.
} 
of the petioles. When the leaf falls and the cell sap evaporates, and the chlorophyll bodies die, the erythrophyll lays hold of the cell wall and solid contents and stains them. In this way dried leaves retain their red color. As erythrophyll is soluble in water, however, contact with moisture will soon cause the most of it to disappear."

An English writer, Mr. Alfred Russell Wallace, notes that chlorophyll is not a simple green pigment, but that it really consists of at least seven distinct substances, varying in color from blue to yellow and orange; and that they differ in their proportions in the chlorophyll of different plants, have different chemical reactions, are differently affected by light, and give distinct spectra. He suggests the collective name chromophyll as a proper one for designating the presence of these various pigments.

Kerner and Oliver in their Natural History of Plants state that "The chemical composition of colouring matters is yet little known, and it is possible that at present a whole group of them is collected together under the name anthocyanin," * and that this substance "appears red in the cell sap in the presence of acids, blue when no acids are present, and violet when the amount of free acids is but small. If there is an abundance of yellow granules together with the acid, red anthocyanin, the leaf assumes an orange color."

Mr. Justus Watson Folsom, in an article on "Autumnal Changes in Leaves" (Garden and Forest, Vol. VIII, p. 392), says:

"A green leaf, or an alcoholic extract of one, viewed through a spectroscope, shows a band of light, or spectrum, which is very characteristic; its dark intervals or absorption bands, resembling those of no other substance. If, now, we mix benzine with our green solution of chlorophyll which we have obtained by soaking, say, elm leaves in alcohol, the liquid separates into two layers, the upper of bluish-green benzine, and the lower of yellow alcohol. These two solutions give different spectra, proving them different substances. Our chlorophyll, then, was a mixture of at least two substances, or, more likely, a chemical compound which broke into two of its constituent compounds, the yellow one being called xanthophyll. Now, this separation presumably occurs when green leaves turn yellow, as is suggested by a simple experiment. If our alcoholic extraction from elm leaves has not been kept in darkness and sealed from the oxygen of the air, it has rapidly decomposed, turning from green to yellow - that is, the green constituent fades away first, gradually revealing the yellow one, which, by the way, some consider the equivalent of the etiolin that always precedes the first formation of the green pigment."

\footnotetext{
* From the Greek words meaning flower and blue.
} 
Mr. Joseph Wharton, in an article, "Observations upon Autumnal Foliage" (American Journal of Scicncc, Vol. 47, p. 253), says that the distinguished French chemist Frémy "separates chlorophyll, when dissolved in alcohol, into two coloring matters, by submitting it to a mixture of ether and chlorohydric acid; the former takes up the yellow matter (phylloxanthin), the latter the blue matter (phyllocyanin), each liquid having distinctly the yellow and the blue color respectively, which being mixed by shaking together form a leaf green. The yellow coloring matter of new sprouts and of etiolated leaves contains phylloxanthin, capable of being developed into chlorophyll; in autumnal yellow leaves the phyllocyanin has been destroyed. The yellow matter, Frémy supposes to be more stable than the blue."

Mention is also made in scientific works of chemists who succeeded in extracting from green leaves pigments of various colors in the form of dried, powdery substances.

All these explanations, simply stated and divested of technical phrases, might read something like this: The substance in a live leaf contains blue and yellow pigments, and, as is well known, these colors when mixed form green. When, through failing vitality the action of these pigments is no longer restrained by the presence of chlorophyll, their colors become apparent. True, no one ever saw a blue leaf: but this color, under the action of the acid remaining in the cell-sap of the leaf, will be stained red. If the yellow substance alone remains the leaf will display that color; and with acids, orange. If the pigmentary substances are absorbed before the leaf falls, the brown walls of the empty cells will give it a russet tint. This explanation is not scientific, and it may not be entirely accurate; but it is fairly deducible from the various and varying statements of the botanists and chemists who have made this subject a matter of scientific research.

\section{Inftuence of Frost.}

There is a popular impression that the autumnal change of leaf color is due to the action of frost; and that early frosts conduce to a more vivid tinting of the foliage. This, however, is an error that a little thought and observation will correct. Some of our trees display red and yellow leaves in August, long before cold weather comes. The brightest red shown in all our autumn foliage is that of a Red Maple on which the leaves turn color in August.

Conceding that the intensity of color differs with the seasons, it may be said that the most brilliant coloring of our forests occurs when a rainy summer is followed by a cool, dry August and September in which there is no frost. Undoubt- 
edly, an early frost may precipitate a change by prematurely hastening the decay or death of the leaf; but the resultant color will be inferior, changing soon to the dull brown which characterizes sear, dead foliage. Moreover, when the fall months are cool and dry the leaves are persistent, and afford a longer display of autumnal tints.

Nor is frost necessary to the falling of the leaves.* Throughout our Northern States much of the foliage of the trees falls before any frost occurs, while in the South the deciduous trees denude their branches without its aid. Frost can kill, but it cannot ripen vegetation. It has been noted also by close observers that while an early frost will check the development of bright leaf colors, a hot, sunny day, about the first of October, will have the same result and loosen the leaves so that they will fall in showers when stirred by the first gentle breeze.

In preparing the colored illustrations of autumn leaves, shown in the accompanying plates, great care was taken to place the specimens as soon as possible in the hands of the artist on whom devolved the task of reproducing the exact tints. This was found to be especially necessary with the yellow leaves, as this class when taken from the tree faded quickly to some extent. With the reds there was not so much need of haste, these colors being more persistent. In order to avoid delay in this respect as far as possible, the specimens were collected mostly in Bronx Park and Northern New Jersey, although excursions for the same purpose were made to the Berkshires and Catskills.

No attempt was made at scientific research; it was sought rather to offer in connection with the text some illustrations showing the typical color assumed in autumn by the leaves of our most common trees, illustrations which might furnish a convenient reference for naturalists if ever needed.

The collection was made by Mr. Abraham Knechtel, F. E., a forester in the employ of this Department, whose scientific attainment and love of nature-study rendered him well qualified for the work. Ample acknowledgment is also due to Mr. William E. Bruchhauser, of New York City, the artist whose skill and enthusiastic co-operation made the accurate reproduction of colors possible.

* Kerner and Oliver. Natural History of Plants, Vol. II, p. 355. 


\section{Common and Botanical Names of Trees Mentioned in this Article.}

So much confusion exists in the use of the common names of our trees that it may be well to append here a list of the species mentioned in the foregoing pages, with the botanical name of each for the purpose of further identification.

Cucumber Tree, Mountain Magnolia,

Tulip Tree, Yellow Poplar, Whitewood,

Basswood, American Linden, Lime,

Ailanthus, Tree of Heaven,

Horse Chestnut,

Red Flowering Horse Chestnut,

White, Silver, Water or Soft Maple,

Red, Scarlet, Swamp or Soft Maple,

Sycamore Maple,

Hard, Rock or Sugar Maple,

Norway Maple,

Schwedler's Maple, Purple Norway,

Ash-leaved Maple, Box Elder,

Staghorn Sumach, Velvet Sumach,

Poison Sumach, Poison Dogwood,

Yellow, Black, or Common Locust,

Kentucky Coffee Tree,

Honey Locust, Three Thorned Acacia,

Black or Wild Cherry,

Mountain Ash,

Sweet Gum, Bilsted, Liquidambar,

Flowering Dogwood,

Pepperidge, Sour Gum, Tupelo,

White Ash,

Black or Swamp Ash,

Western or Hardy Catalpa,

Sassafras,

English Elm,

American or White Elm,

Hackberry, Sugarberry, Nettle Tree,
Magnolia acuminata I

Liriodendron tulipifera $\mathrm{L}$.

Tilia americana L.

Ailanthus glandulosa Desf."

Aesculus hippocastanum L:

Aesculus rubicunda.

Acer Ehrown. -

Acer rubrum L.

Acer pseudoplatanus L.

Acer saccharum Marsh-

Acer platanoides L.

Acer platanoides schwedleri.

Acer negundo L.-

Rhus typhina L.

Rhus vernix L.

Robinia pseudacacia L.

Gymnocladus dioicus C. Koch.

Gleditsia triacanthos

Prunus serotina Ehrh.

Pyrus americana de C.

Liquidambar styraciflua L.

Cornus florida L.

Nyssa sylvatica Marsh.

Fraxinus americana $\mathrm{L}$.

Fraxinus nigra Marsh.

Catalpa speciosa Warder.

Sassafras sassafras Karst.

Ulmus campestris $\mathrm{L}$.

Ulmus americana L

Celtis occidentalis $\mathrm{L}$. 
Sycamore, Plane Tree, Buttonwood, Buttonball, European Sycamore, Oriental Plane Tree,

Butternut, White Walnut,

Black Walnut,

Shellbark or Shagbark Hickory,

White Birch,

Canoe or Paper Birch,

Black, Sweet or Cherry Birch,

Yellow or Gray Birch,

European Birch, Cut-leaved Birch,
Platanus occidentalis $\mathrm{L}$.

Platanus orientalis $\mathrm{L}$.

Juglans cinerea $\mathrm{L}$.

Juglans nigra L.

Hicoria ovata Britt.

Betula populifolia Marsh.

Betula papyrifera Marsh.

Betula lenta L.

Betula lutea Michx. f.

Betula alba var. laciniata.

Hop Hornbeam, Ironwood, Leverwood, Hardhack, Ostrya virginiana K. Koch.

Blue or Water Beech, Ironwood, Leverwood,

Carpinus caroliniana Walt.

White Oak,

Red Oak,

Quercus aiba $\mathrm{L}$

Quercus rubra L.

Scarlet Oak,

Quercus coccinea Wang.

Black or Yellow-barked Oak,

Pin Oak, Swamp Spanish Oak,

Scrub Oak,

Chestnut,

Beech,

Purple or Copper Beech,

Bay Willow,

Small American Aspen, Poplar, "Popple,"

Large American Aspen, Saw-tooth Poplar,

Lombardy Poplar,

Quercus velutina Lam.

Quercus palustris Muench.

Quercus nigra

Castanea dentata Borkh.

Fagus americana Sweet.

Fagus sylvatica var. purpurea.

Salix pentandra L.

Populus tremuloides Michx.

Populus grandidentata Michx.

Populus dilatata L.

Cottonwood, Carolina Poplar, Necklace Poplar, White Pine,

Populus deltoides Marsh.

Pinus strobus L.

Tamarack, Hackmatack, American Larch, Ginkgo,

Larix americana Michx.

Salisburia adiantifolia $\mathrm{Sm}$ 









